\section{BAKTERIOLOGI DASAR}

Chylen Setiyo Rini, S.Si., M.Si

Jamilatur Rochmah, M.Si
ISBN 978-623-6833-66-7 (PDF)

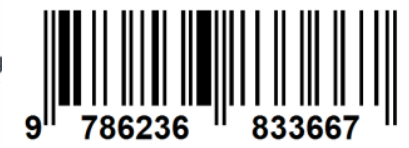

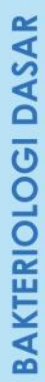

BAKTERIOLOGI DASAR

Chylen Setiyo Rini, S.Si., M.Si

Jamilatur Rochmah, M.Si 


\title{
BUKU AJAR MATA KULIAH BAKTERIOLOGI DASAR
}

\author{
Oleh \\ Chylen Setiyo Rini, S.Si., M.Si \\ Jamilatur Rohmah, S.Si., M.Si.
}

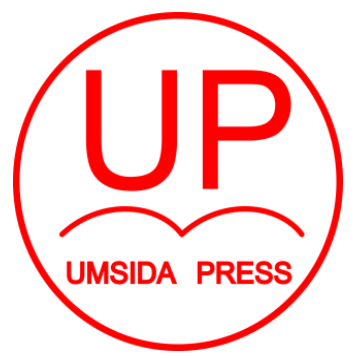

UMSIDA PRESS

SIDOARJO 
BUKU AJAR

BAKTERIOLOGI DASAR

Penulis :

Chylen Setiyo Rini, S.Si., M.Si.

Jamiltur Rohmah, S.Si., M.Si

ISBN :

978-623-6833-66-7

\section{Editor :}

Miftahul Mushlih, M.Sc.

Design Sampul dan Tata Letak :

Mochammad Nashrullah, S.Pd.

Amy Yoga Prajati, S.Kom.

\section{Penerbit :}

UMSIDA Press

Anggota IKAPI No. 218/Anggota Luar Biasa/JTI/2019

Anggota APPTI No. 0020181092017

\section{Redaksi :}

Universitas Muhammadiyah Sidoarjo

Jl. Mojopahit No 666B

Sidoarjo, JawaTImur

Cetakan pertama, September 2020

(C) Hak cipta dilindungi undang-undang

Dilarang memperbanyak karya tulis ini dengan suatu apapun tanpa ijin tertulis dari penerbit. 


\section{KATA PENGANTAR}

Puji syukur kehadirat Tuhan Yang Maha Esa yang telah melimpahkan hidayahnya sehingga penulis dapat menyusun "Buku Ajar Bakteriologi Dasar" dengan baik. Buku ini membahas mengenai struktur dan morfologi bakteri, pertumbuhan bakteri, klasifikasi dan identifikasi bakteri serta bakteri patogen pada manusia.

Buku ini dapat disusun dengan baik berkat kerjasama dan bantuan dari berbagai pihak. Oleh karena itu saya sampaikan banyak terima kasih kepada segenap pihak yang telah berkontribusi secara maksimal dalam penyelesaian buku ini.

Penulis menyadari bahwa masih banyak kekurangan dalam penulisan buku, baik dari segi tata bahasa, susunan kalimat maupun isi. Oleh karena itu penulis menerima segala kritik dan saran yang membangun dari para pembaca.

Akhir kata semoga buku ini dapat menambah khazanah ilmu pengetahuan dan memberikan manfaat khususnya bagi prodi D-IV Teknologi Laboratorium Medis Fakultas Ilmu Kesehatan Universitas Muhammadiyah Sidoarjo.

Sidoarjo, September

2020

Penulis 


\section{DAFTAR ISI}

HALAMAN SAMPUL

IDENTITAS BUKU

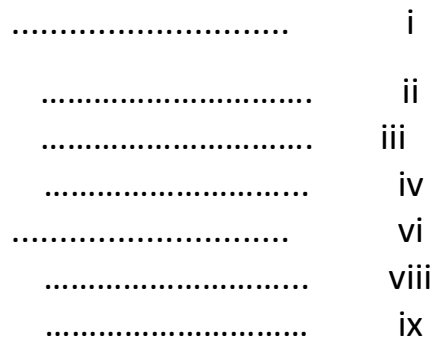

KATA PENGANTAR

DAFTAR ISI

DAFTAR GAMBAR

DAFTAR TABEL

BATANG TUBUH DAN SUB CPMK

BAB I SEJARAH MIKROBIOLOGI DAN KLASIFIKASI BAKTERI

1.1 Sejarah Mikrobiologi

1. 2 Klasifikasi Mikroorganisme

1.3 Sel Prokariotik dan Eukariotik

1.4 Manfaat dan Mikroorganisme

1.5 Mikroorganisme Yang Merugikan

\section{BAB II MORFOLOFI BAKTERI}

2.1 Bakteri

25

2.2 Bentuk Bakteri

2.3 Struktur Bakteri

2.4 Bakeri Berdasarkan Struktur Dinding Sel

2.5 Persamaan dan Perbedaan Bakteri Gram

Positif dan Bakteri Gram Negatif

\section{BAB III PERTUMBUHAN BAKTERI}

3.1 Pertumbuhan Bakteri

3.2 Kurva Pertumbuhan Bakteri

3.3 Pengendalian Pertumbuhan Mikroorganisme

\section{BAB IV BAKTERI PATOGEN PADA MANUSIA}

4.1 Infeksi Bakteri 
4.2 Kelompok Bakteri Patogen

BIODATA PENULIS 


\section{DAFTAR GAMBAR}

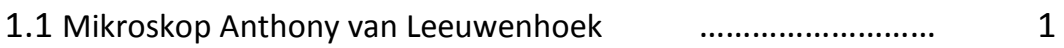

1.2 Percobaan Franscesco Redi $\quad$............................. 4

1.3 Percobaan Lazzaro Spalanzani $\quad$........................... 5

1.4 Percobaan Louis Pasteur $\quad$............................ 6

1.5 Klasifikasi Menurut Carl Woese $\quad$.......................... 15

1.6 Sel Prokariotik (bakteri) dan Sel $\quad$.......................... 19

Eukariotik (Tumbuhan dan Hewan)

2.1 Perbedaan Dinding (a) Sel Bakteri

Gram Positif dan(b) sel Bakteri Gram Negatif

2.2 Sel Bakteri

37

2.3 Flagella Pada Bakteri

2.4 Bentuk Flagel Bakteri

2.5 Kapsul Pada Bakteri

41

2.6 Kapsul (berwarna putih) pada Bakteri

42

2.7 Endospora Bakteri

43

2.8 Pewarnaan Bakteri Gram Positif dan

Bakteri Gram Negatif

3.1 Kurva Pertumbuhan Bakteri

56

3.2 Pembelahan Biner

65

3.3 Proses Transformasi

67

3.4 Proses Transduksi

68

3.5 Proses Konjugasi

69

4.1. Infeksi Ulkus Diabetikum

80

4.2 Kerusakan jaringan paru akibat

80 pneumonia oleh K.pneumonia

4.3 A. Gonore Pada Pria; B. Gonore Pada Wanita

4.4 Penyakit Frambusia Pada Telapak Tangan

4. 5 Infeksi Chlamydia trachomatis pada serviks

4.6 Penyakit Pes atau Plague 
4.7 Sifilis pada Genital Pria

92

4.8 Radang Tenggorokan

93

4.9 Lepra

96

4.10. Vaginosis bakterial pada Vagina

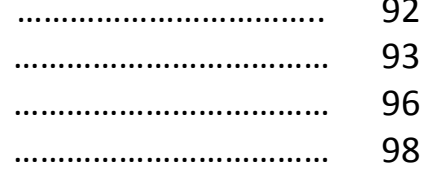




\section{DAFTAR TABEL}

1.1 Perkembangan Sistem Klasifikasi

Makhluk Hidup

1.2 Perbedaan Sel Prokariotik dan Eukariotik

20

2.1 Perbedaan Susunan Dinding Bakteri

33

Gram Positif dan Gram Negatif

2.2 Bakteri Gram Positif

2.3 Bakteri Gram Negatif

45

2.4 Perbedaan Bakteri Gram Positif dan

46

Bakteri Gram Negatif

4.1 Perbedaan Endotoksin dan

Eksotoksin 


\section{BATANG TUBUH DAN \\ SUB-CAPAIAN PEMBELAJARAN MATA KULIAH}

\begin{tabular}{|c|c|}
\hline BAB & Sub-Capaian Pembelajaran Mata Kuliah \\
\hline $\begin{array}{l}\text { BAB I } \\
\text { MORFOLOGI } \\
\text { BAKTERI }\end{array}$ & $\begin{array}{l}\text { 1. Mahasiswa mampu memahami konsep bentuk } \\
\text { sel bakteri } \\
\text { 2. Mahasiswa mampu memahami konsep struktur } \\
\text { sel bakteri }\end{array}$ \\
\hline $\begin{array}{l}\text { BAB II } \\
\text { PERTUMBUHAN } \\
\text { BAKTERI }\end{array}$ & $\begin{array}{l}\text { 1. Mahasiswa mampu memahami konsep } \\
\text { pertumbuhan bakteri } \\
\text { 2. Mahasiswa mampu memahami konsep faktor- } \\
\text { faktor pertumbuhan bakteri } \\
\text { 3. Mahasiswa mampu memahami siklus } \\
\text { pertumbuhan bakteri }\end{array}$ \\
\hline $\begin{array}{l}\text { BAB III } \\
\text { KLASIFIKASI } \\
\text { DAN } \\
\text { IDENTIFIKASI } \\
\text { BAKTERI }\end{array}$ & $\begin{array}{l}\text { 1. Mahasiswa mampu mengklasifikasi bakteri } \\
\text { 2. Mahasiswa mampu mengidentifikasi bakteri. }\end{array}$ \\
\hline $\begin{array}{l}\text { BAB IV } \\
\text { BAKTERI } \\
\text { PATOGEN PADA } \\
\text { MANUSIA }\end{array}$ & $\begin{array}{l}\text { 1. Mahasiswa mampu memahami konsep bakteri } \\
\text { patogen } \\
\text { 2. Mahasiswa mampu memahami konsep } \\
\text { kelompok bakteri patogen }\end{array}$ \\
\hline
\end{tabular}




\section{BAB I SEJARAH MIKROBIOLOGI DAN KLASIFIKASI \\ BAKTERI}

\section{TUJUAN INSTRUKSIONAL:}

1. Mahasiswa mengetahui sejarah Mikrobiologi

2. Mahasiswa mengetahui klasifikasi pada mikroorganisme

3. Mahasiswa mengetahui sel prokariot dan eukariot

4. Mahasiswa mengetahui manfaat mikroorganisme

5. Mahasiswa mengetahui mikroorganisme yang merugikan

\subsection{Sejarah Mikrobiologi}

Mikrobiologi merupakan cabang ilmu biologi yang mempelajari mikroorganisme. Ilmu dasar yang diperlukan untuk mendukung pemahaman tentang mikrobiologi yaitu ilmu kimia, fisika, dan biokimia. Saat ini penelitian tentang mikroorganisme dilakukan secara intensif untuk mengetahui dasar fenomena biologi hal ini disebabkan mikroorganisme memiliki sifat sifat sangat sederhana, perkembangbiakannya sangat cepat, dan memiliki berbagai variasi metabolisme.

Ditemukannya dunia mikroorganisme berawal dari penemuan mikroskop oleh Anthony van Leeuwenhoek (16331723). Pada masa inimikroskop yang ditemuan masih sangat sederhana yang hanya dilengkapi satu lensa dengan jarak fokus yang sangat pendek, tetapi dapat menghasilkan bayangan yang jelas setara dengan perbesaran 50-300 kali. Pengamatan yang dilakukan oleh Leeuwenhoek adalah pengamatan terhadap struktur mikroskopis pada biji, jaringan tumbuhan, dan invertebrata kecil. 
Pada zamannya penemuan ini merupakan penemuan terbesar yang menemukan dunia mikroorganisme dikenal dengan animalculus atau hewan kecil. Animalculus merupakan bermacammacam jenis mikroorganisme yang pada saat ini diketahui sebagai protozoa, algae, khamir, dan bakteri.

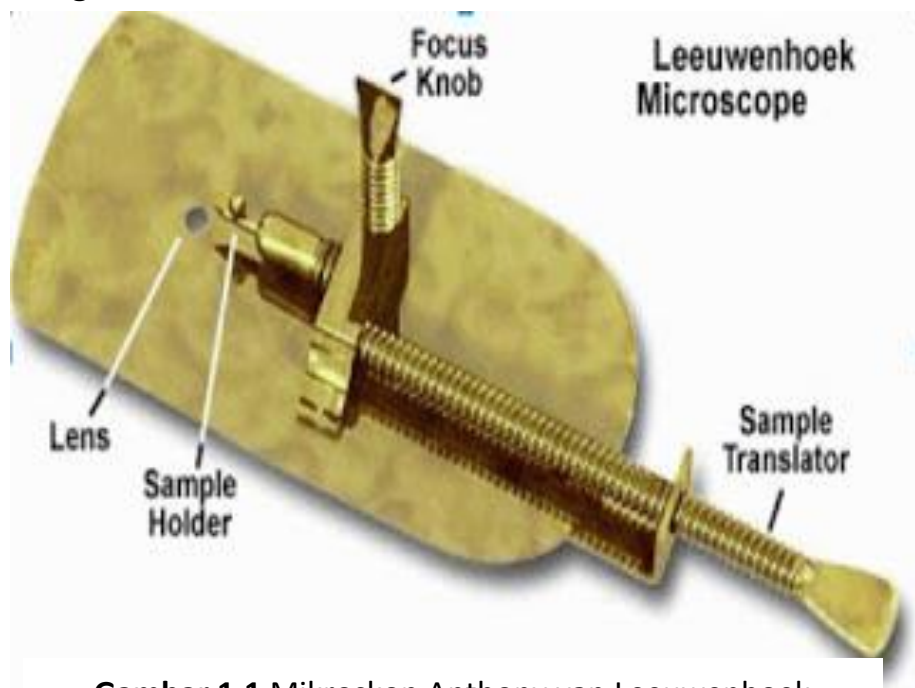

Gambar 1.1 Mikroskop Anthony van Leeuwenhoek

Penemuan Leewenhoek tentang animalcules menjadi perdebatan dari mana asal animalcules tersebut. Ada dua pendapat yang muncul yang dikenal dengan teori abiogeneis dan biogenesis.

a. Menurut teori abiogenesis berpendapat bahwa animalcules muncul dengan sendirinya dari bahan-bahan mati. Doktrin tentang abiogenesis dianut sampai jaman Renaissance, seiring dengan kemajuan pengetahuan mengenai mikroba, semakin lama doktrin tersebut menjadi tidak terbukti.

b. Menurut teori biogenesis berpendapat bahwa animalculus terbentuk dari "benih" animalculus selalu berada di 
udara. Untuk mempertahankan pendapat tersebut maka penganut teori ini mencoba membuktikan dengan berbagai percobaan.

Para ahli yang membuktikan kebenaran teori biogenesis antara lain:

i). Franscesco Redi (1926-1697)

Seorang ahli kedokteran Italia mencoba membuktikan ketidakbenaran pendapat "generatio spontanea" dari hasil percobaannya membuktikan bahwa ulat yang terdapat pada daging busuk adalah larva yang berasal dari telur lalat, bukan berasal dari benda mati (teori Generatio Spontanea). Percobaan Franscesco Redi yaitu:

$>$ Pada toples yang ditutup, tidak ada belatung sama sekali

$>$ Pada toples yang hanya ditutupi kain kasa terdapat belatung diatas kain kasa dan sedikit pada daging

Pada toples yang terbuka terdapat banyak belatung pada daging

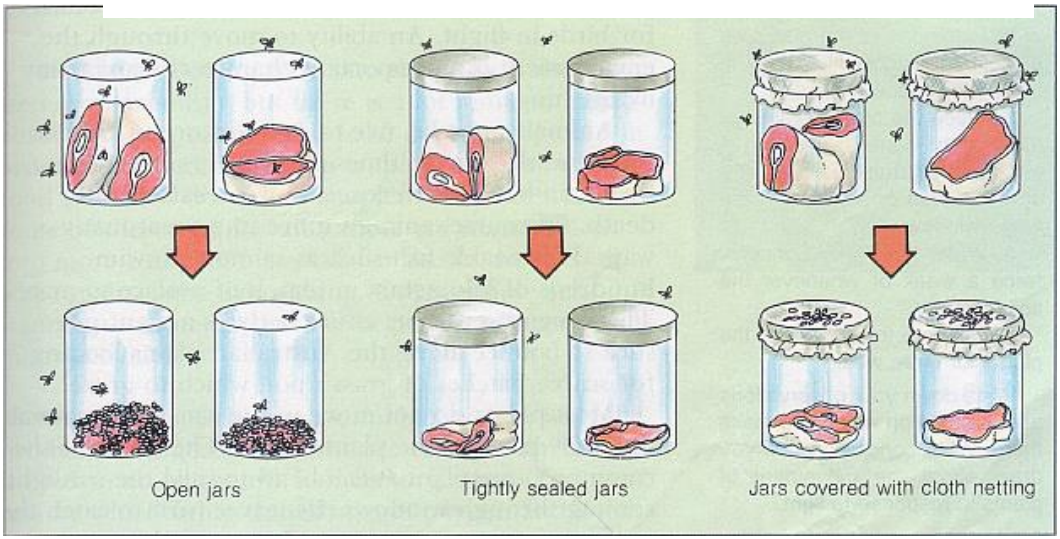

Gambar 1.2 Percobaan Franscesco Redi 
ii) Lazzaro Spalanzani (1729-1799)

Hasil eksperimen lazzaro Spalanzani Memberikan bukti yang kuat bahwa mikroba tidak muncul dengan sendirinya, pada percobaan dengan menggunakan kaldu menghasilkan bahwa dengan pemanasan dapat menyebabkan animalculus tidak tumbuh. Pada percobaan ini dapat menunjukkan bahwa terdapat perkembangan mikrobia di dalam suatu bahan sehingga menyebabkan terjadinya perubahan kimiawi pada bahan tersebut.

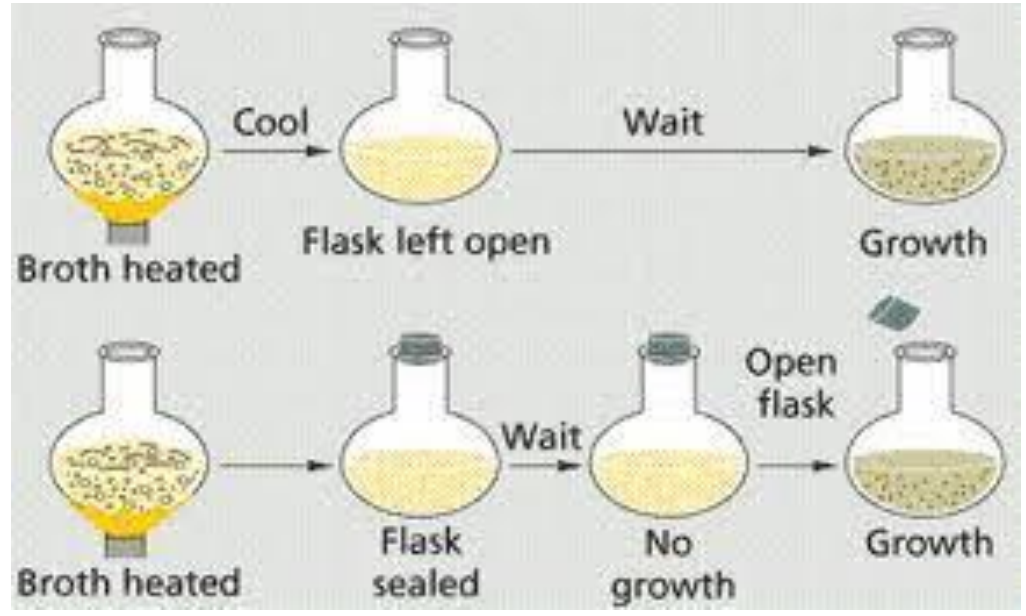

Gambar 1.3 Percobaan Lazzaro Spalanzani

iii) Louis Pasteur (1822-1895)

Merupakan seorang ahli kimia yang memberikan perhatian khusus pada mikroorganisme. Louis pasteur tertarik untuk meneliti peran mikroorganisme dalam industri anggur, terutama pada pembuatan alkohol.Eksperimen Pasteur yang terkenal yakni menggunakan bejana leher panjang yang dibengkokkan yang 
dikenal dengan leher angsa. Bejana ini berisi kaldu yang dipanaskan. Pada kondisi tersebut udara dapat dengan bebas melewati tabung atau pipa leher angsa tetapi di daerah kaldu tidak ditemukan adanya mikroorganisme. Hasil eksperimen menunjukkan mikroorganisme beserta debu akan mengendap pada bagian tabung yang berbentuk $U$ sehingga tidak dapat mencapai kaldu. Pasteur juga melakukan eksperimen yang sama dengan membawa tabung tersebut ke pegunungan Pyrenes dan Alpen. Berdasarkan hasil pengamatan ditemuka bahwa mikroorganisme terbawa debu oleh udara, sehingga Pasteur menyimpulkan bahwa semakin bersih atau murni udara yang masuk ke dalam bejana, semakin sedikit kontaminasi yang terjadi.

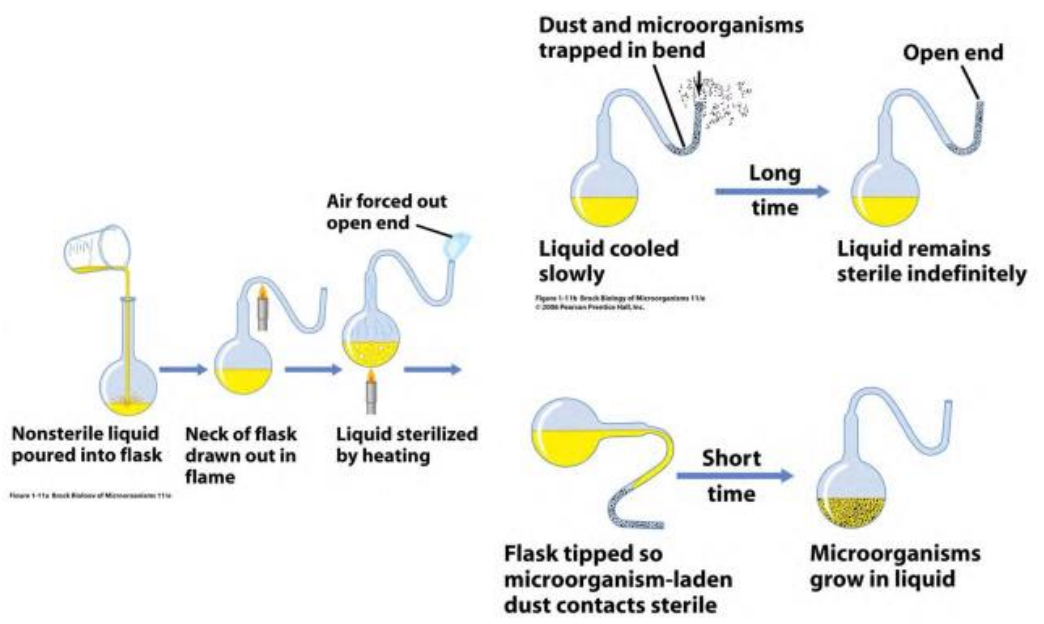

Gambar 1.4 Percobaan Louis Pasteur

Pada tahun 1842-1910 Robert Koch merupakan seorang dokter dari Jerman yang mengamati tentang antraks. la mengisolasi bakteri dari darah biri-biri yang mati disebabkan penyakit antraks dengan bakteri berbentuk batang dengan ujung- 
persegi (basilus). Bakteri tersebut diberi nama Bacillus anthracis. Bakteri itu ditumbuhkan pada media bernutrisi dan menyuntikkannya pada sapi yang sehat. Kemudian sapi ini menjadi sakit serta mati. Koch kemudian mengisolasi bakteri yang berasal dari darah sapi serta membandingkannya dengan kultur bakteri yang terlebih dahulu diisolasi, jadi kedua kultur tersebut berisi bakteri yang sama. Dari temuan ini meyakinkan jika penyakit dapat disebabkan dari bakteri. Bersumber dari penemuannya, Koch merupakan orang pertama yang menciptakan konsep hubungan antara penyakit menular dan mikroorganisme disebut dengan Postulat Koch yang sekarang menjadi acuan penentu penyakit menular. Postulat Koch berisi tentang:

a) Bakteri dapat ditemukan pada tubuh hewan yang sakit.

b) Bakteri harus dapat diisolasi serta dibiakkan dalam bentuk biakkan murni di luar tubuh hewan tersebut.

c) Biakkan murni tersebut harus dapat menyebabkan penyakit yang sama pada hewan coba. Bakteri penyebab penyakit harus dapat diisolasi kembali.

Perkembangan mikrobiologi pada masa sejarah memasuki periode keemasan dengan ditemukannya alat bantu mikroskop untuk mengamati jasad renik. Tahun 1664 Robert Hooke, mengilustrasikan struktur reproduktif dari Moulds (sejenis kapang). Abad 19 konstruksi mikroskop mulai dikembangkan dan disebarluaskan. Pada abad 19, penelitian tertuju pada perkembangan teknik yang menghasilkan prosedur dasar laboratorium mikrobiologi dalam mengisolasi, mengkultivasi dan mengidentifikasi mikroorganisme.

Pada abad ke-20 bidang mikrobiologi berkembang secara cepat menjadi dua arah, yaitu dasar dan terapan. Pada bidang 
terapan kemajuan praktis yang dibuat oleh Koch mengarah pada peningkatan perkembangan dalam bidang kedokteran dan imunologi. Ada beberapa bakteri patogen baru yang ditemukan pada awal abad ke 20 serta ditemukannya prinsip bahwa bakteri patogen dapat menginfeksi tubuh serta tahan terhadap sistem kekebalan tubuh. Hal ini terjadi akibat penggunaan berbagai antibiotik yang jumlah dosisnya tidak tepat, sehingga menyebabkan terbentuknya proses kekebalan pada bakteri patogen.

Pada akhir abad 20, aplikasi mikrobiologi yang utama pada bidang pertanian mengalami kemajuan sangat pesat, dengan ditemukannya proses dasar mikroba dalam tanah yang bermanfaat dan berbahaya bagi pertumbuhan tanaman, seperti ditemukannya bakteri pengikat nitrogen bebas dari udara yang berguna sebagi upaya peningkatan kesuburan tanah. Disamping itu ditemukannya bermacam-macam mikroorganisme patogen penyebab penyakit pada bemacam-macam tumbuhan, sehingga dapat diketahui cara pencegahannya. Penelitian mengenai mikrobiologi terapan pada bidang kedokteran dan industri mengarah pada manfaat penggunaan mikroba dalam pembentukan antibiotik dan industri kimia. Awal pertengahan abad 20 penemuan bakteri baru dan klasifikasinya (taxonomi bakteri) merupakanpenemuan terpenting dan terbesar. Dalam mengklasifikasikan bakteri memerlukan penelitian tentang nutrisi yang dibutuhkan dan produk yang dihasilkannya, dalam bidang fisiologi bakteri melibatkan studi tentang struktur fisik dan kimia bakteri, yang dibahas dalam sitologi bakteri. Penemuan penting lainnya yaitu pada bidang fisiologi bakteri merupakan studi enzim yang dihasilkan oleh bakteri dan reaksi kimia yang dihasilkannya. Sedangkan genetika 
bakteri melibatkan studi tentang hereditas dan variasi bakteri selama pertumbuhan dan perkembangannya.

\section{2 Klasifikasi Mikroorganisme}

Definisi mikroorganisme atau mikroba adalah organisme yang berukuran kecil atau organisme bersel tunggal yang hanya dapat dilihat dengan menggunakan mikroskop. Kelompok mikroba antara lain protozoa, alga, jamur, bakteri dan virus. Dunia mikroorganisme sangat luas sehingga perlu dikelompokkan atau pengklasifikasian untuk mempermudah menggolongkannya. Sejarah perkembangan klasifikasi menurut Whittaker (1969) system klasifikasi 5 kingdom yaitu prokaryotik (monera), eukariotik uniseluler (protista), eukariotik multiseluler, multinukleat (Fungi, animalia, plantae). Sistem klasifikasi terbaru dikemukakan oleh Carl Woese yang membagi organisme menjadi 3 kingdom yaitu Archaea/Archaebacteria, eubacteria/bakteri, eucarya. Pembagian kingdom ini dikembangkan berdasarkan makromolekul organismea terutama ribosom RNA. Pada tingkatan genetis molekuler bahwa archaea, bakteri, eukarya memiliki perbedaan yang yang besar. Sistem klasifikasi sampai tahun 2015 oleh Ruggiero mengklaksifikasikan menjadi 7 kingdom.

IImu yang mempelajari tentang klasifikasi maupun pembagian sistematis organisme kedalam suatu kelompok maupun golongan disebut Taksonomi. Klasifikasi adalah penyusunan ataupun penataan organisme kedalam kelompok taksonomi menurut kemiripannya. Sedangkan sistematuka mikroba yaitu pengklasifikasian, penamaan dan pengidentifikasian mikroba, biasanya untuk mengklasifikasikan bakteri secara 
terperinci menggunakan buku Bergey's Manual of Determinative Bacteriology. Menurut Bergey's Manual of Determinative Bacteriology Prokariota dibagi menjadi 4 divisi utama, berdasarkan karakteristik dinding sel adalah :

1. Gracilicutes : Bakteri Gram Negatif

2. Firmicutes : Bakteri Gram Positif

3. Tenericutes : Bakteri tanpa dinding sel

4. Archaebacteria

Pembagian grup atau kelompok bakteri berdasarkan buku bergey's manual dapat digolongkan menjadi:

A. Bakteri Berbentuk Kokus (bulat)

1) Bakteri Kokus Gram Positif (grup 14)

Aerobik: Micrococcus, Staphylococcus, Streptococcus, Leuconostoc Anaerobik: Methanosarcina, Thiosarcina, Sarcina, Ruminococcus

2) Bakteri Kokus Gram Negatif

Aerobik: Neisseria, Moraxella, Acinetobacter, Paracoccus (grup 10) Anaerobik: Veillonella, Acidaminococcus, Megasphaera (grup 11)

\section{B. Bakteri Berbentuk Batang}

\section{a. Bakteri Gram Positif}

1. Bakteri Gram Positif Tidak Membentuk Spora (grup 16) Aerobik: Lactobacillus, Listeria, Erysipelothrix, Caryophanon.

2. Bakteri Coryneform Dan Actinomycetes (grup 17)

Aerobik Coryneform: Corynebacterium, Arthrobacter, Brevibacterium, Cellulomonas, Propionibacterium, Eubacterium, Bifidobacterium. Aerobik Actinomycetes: Mycobacterium, Nocardia, Actinomyces, Frankia, 
Actinoplanes,

Dermatophilus,

Micromonospora,

Microbispora, Streptomyces, Streptosporangium.

\section{Bakteri Pembentuk Endospora (grup 15)}

Aerobik: Bacillus, Sporolactobacillus, Sporosarcina, Thermoactinomyces

Anaerobik: Clostridium, Desulfotomaculum, Oscillospira

\section{b. Bakteri Gram Negatif}

\section{Bakteri Gram Negatif Aerobik (grup 7)}

Aerobik: Pseudomonas, Xanthomonas, Zoogloea, Gluconobacter, Acetobacter, Azotobacter, Azomonas, Beijerinckia, Derxia, Rhizobium, Agrobacterium, Alcaligenes, Brucella, Legionella, Thermus.

\section{Bakteri Gram Negatif Aerobik Khemolitotrofik (Grup12)}

Aerobik: Nitrobacter, Nitrospira, Nitrococcus, Nitrosomonas, Nitrosospira, Nitrosococcus, Nitrosolobus. Bakteri ini umumnya berfungsi pada proses nitrifikasi di dalam tanah. Contohnya Thiobacillus, Sulfolobus, Thiobacterium, Thiovolum yang merupakan bakteri yang berperan dalam proses oksidasi sulfur di alam.

\section{Bakteri Berselubung (Grup 3)}

Aerobik: Sphaerotilus, Leptothrix, Cladothrix, Crenothrix. Bakteri Sphaerotilus biasanya hidup di saluran-saluran air. Leptothrix dan Cladothrix merupakan bakteri yang mampu mengoksidasi besi atau penyebab korosi.

\section{Bakteri Gram Negatif Fakultatif Anaerobik (Grup 8)}

Fakultatif anaerobik: Escherichia coli, Klebsiella, Enterobacter, Salmonella, Shigella, Proteus, Serratia, Erwinia, Yersinia, Vibrio, Aeromonas, Photobacterium. 


\section{Bakteri Gram Negatif Anaerobik (Grup 9)}

Anaerobik: Bacteroides, Fusobacterium, Leptotrichia

\section{Bakteri Methanogens Dan Arkaebakteria (Grup 13)}

Anaerobik: Methanobacterium, Methanothermus, Methanosarcina, Methanothrix, Methanococcus. Bakteri ini merupakan pembentuk metan $\left(\mathrm{CH}_{4}\right)$ dari hasil perombakan bahan organik secara anaerobik. Aerobik: Halobacterium, Halococcus, Thermoplasma. Bakteri ini ada yang tahan hidup pada kadar garam tinggi dan dan ada yang tahan pada suhu tinggi.

Anaerobik: Thermoproteus, Pyrodictium, Desulforococcus.

\section{Bakteri Berbentuk Lengkung}

\section{Bakteri Gram Negatif Spiril Dan Lengkung (Grup 6)}

Aerobik. contohnya Spirillum, Aquaspirillum, Azospirillum, Oceanospirillum, Campylobacter, Bdellovibrio, Microcyclus, Pelosigma.

\section{Bakteri Gram Negatif Lengkung Anaerobik (Grup 9)}

Anaerobik: Desulfovibrio, Succinivibrio, Butyrivibrio, Selenomonas.

\section{Spirochaeta (Grup 5)}

Aerobik dan anaerobik: Spirochaeta, Cristispira, Treponema, Borrelia, Leptospira. Bakteri ini berbentuk benang tipis dan terulir. Dinding sel tipis dan lentur. Bakteri ini dapat bergerak dengan cara kontraksi sel menurut garis sumb selnya. Selnya berukuran 0,1-3 $\mu \mathrm{m} x$ 4-8 $\mu \mathrm{m}$.

D. Bakteri Yang Termasuk Kelompok Khusus

1. Bakteri Yang Merayap (Meluncur) (Grup 2) 
Bakteri ini dapat merayap walaupun tidak berflagela. Bakteri ini selalu bersifat gram negatif. Dalam kelompok ini termasuk beberapa ganggang biru, beberapa bakteri khemoorganotrof dan beberapa bakteri belerang (sulfur). Kelompok bakteri yang menjadi anggota bakteri merayap (meluncur) sebagai berikut:

a) Bakteri yang mengandung sulfur intraselular, berbentuk benang. Contoh: Beggiatoa, Thiothrix, Achromatium.

b) Bakteri bebas sulfur, membentuk trikoma (bulu). Contoh: Vitreoscilla, Leucothrix, Saprospira.

c) Bakteri uniselular, bentuk batang pendek. Contoh: Cytophaga, Flexibacter, Myxobacteria.

d) Bakteri fototrof yang bergerak merayap. Contoh: Chloroflexus

e) Cyanobacteria yang bergerak merayap. Contoh: Oscillatoria

\section{Bakteri Bertangkai Atau Bertunas (Grup 4)}

Bakteri ini mempunyai struktur mirip tangkai atau tunas yang merupakan tonjolan dari sel, atau hasil pengeluaran lendir. Contoh: Hypomicrobium, Caulobacter, Prosthecomicrobium, Ancalomicrobium, Gallionella, Nevskia.

\section{Bakteri Parasit Obligat: Rickettsiae Dan Chlamydiae (Grup} 18)

Merupakan bakteri yang berukuran paling kecil, tetapi lebih besar dari virus, yaitu $0,3 \times 2 \mu$. Bentuk sel pleomorfik, dapat berupa batang, kokus, atau filamen. Bakteri ini cara hidupnya sebagai parasit sejati (parasit obligat) di dalam sel jasad lain dan bersifat patogen. Hidupnya intraselular di 
dalam sitoplasma dan inti sel binatang dan manusia. Oleh karena itu bakteri kelompok ini merupakan penyebab penyakit, yang biasanya ditularkan oleh vektor serangga. Contoh: Rickettsia prowazekii, Chlamydia trachomatis, Coxiella burnetii.

\section{Mycoplasma (Klas Mollicutes) (Grup 19)}

Mycoplasma disebut juga PPLO (Pleuropneumonia Like Organisms). Cirinya yaitu tidak mempunyai dinding sel, atau merupakan bentuk $L$ dari bakteri sejati (Eubakteria) atau bentuk speroplas sel eubakteria, sehingga sifatnya mirip bakteri sejati. Mycoplasma berukuran 0,001-7 $\mu$. Contoh: Mycoplasma mycoides, M. homonia, $M$. orale, Acholeplasma, Spiroplasma.

\section{Bakteri Anaerobik Anoksigenik Fototrofik (Grup 1)}

Bakteri ini mempunyai ciri berpigmen fotosintetik. Ada yang berbentuk kokus, batang, dan lengkung. Berdasarkan sifat fisiologinya dapat dibagi menjadi:

a) Familia Thiorhodaceae (bakteri sulfur ungu). Contoh: Thiospirillum sp., Chromatium sp.

b) Familia Athiorhodaceae/Rhodospirillaceae (bakteri sulfur non-ungu). Contoh: Rhodospirillum, Rhodopseudomonas.

c) Familia Chlorobiaceae (bakteri sulfur hijau). Contoh: Chlorobium, Chloropseudomonas, Chlorochromatium.

\section{Bakteri Aerobik Oksigenik Fototrofik: Cyanobacteria (Grup} 20)

Bakteri ini termasuk Myxophyceae atau Cyanophyceae. Sifatnya yang mirip bakteri adalah dinding selnya terdiri mukokompleks, tidak berdinding inti, tidak ada mitokondria dan kloroplas. Sifatnya yang berbeda adalah dapat berfotosintesa mirip tumbuhan tingkat tinggi, dan 
menghasilkan $\mathrm{O}_{2}$. Bakteri ini mempunyai klorofil a dan fikobilin (fikosianin dan fikoeritrin). Bentuk selnya tunggal (uniselular), koloni, dan benang-benang (filamen). Selnya dapat bergerak meluncur tetapi sangat lambat (250 $\mu$ per menit), meskipun tidak berflagela. Cara hidupnya bebas, dan berasosiasi simbiosis. Contoh: Gloeobacter, Gloeocapsa, Dermocarpa, Spirulina, Nostoc, Anabaena, Oscillatoria, Calothrix, Cylindrospermum.

Untuk mengidentifikasi bakteri bisa dilakukan pemeriksaan secara langsung yaitu dengan:

a) Pemeriksaan mikroskopis adalah pemeriksaan bertujuan mengamati pergerakan, pembelahan, bentuk dan ukuran sel.

b) Pewarnaan adalah mengamati reaksi sel bakteri terhadap zat pewarna dan sistem pewarnaannya. Tujuan dilakukan pewarnaan Gram adalah untuk mengetahui bakteri Gram positif dan bakteri Gram negatif. Jika untuk mengetahui bakteri Tuberculosis menggunakan pewarnaan tahan asam. Untuk melihat struktur bakteri dapat menggunakan pewarnaan flagella, kapsul, spora, granula.

c) Aktivitas biomikia bakteri. Mikroba memiliki suatu karakteristik yang khas, yang dapat dilihat dati karakteristik biokimianya.

Tabel 1.1 Perkembangan Sistem Klasifikasi Makhluk Hidup

\begin{tabular}{|c|c|c|c|c|c|c|c|c|c|}
\hline $\begin{array}{l}\text { Linnaeus } \\
(\mathbf{1 7 3 5})\end{array}$ & $\begin{array}{l}\text { Haeckel } \\
\text { (1866) }\end{array}$ & $\begin{array}{c}\text { Chatton } \\
\text { (1925) }\end{array}$ & $\begin{array}{l}\text { Copeland } \\
\text { (1938) }\end{array}$ & $\begin{array}{c}\text { Whittaker } \\
\text { (1969) }\end{array}$ & $\begin{array}{c}\text { Woese, dkk } \\
\text { (1977) }\end{array}$ & $\begin{array}{c}\text { Woese, dkk } \\
\text { (1990) }\end{array}$ & $\begin{array}{c}\text { Cavalier-Smith } \\
\text { (1993) }\end{array}$ & $\begin{array}{c}\text { Cavalier-Smith } \\
\text { (1998) }\end{array}$ & $\begin{array}{c}\text { Ruggiero, dkk } \\
\text { (2015) }\end{array}$ \\
\hline 2 Kingdom & 3 Kingdom & 2 Empire & 4 Kingdom & 5 Kingdom & 6 Kingdom & 3 Domain & 8 Kingdom & 6 Kingdom & 7 Kingdom \\
\hline \multirow{5}{*}{ 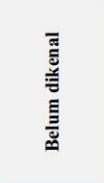 } & \multirow{5}{*}{ Protista } & \multirow{2}{*}{ Prokariota } & \multirow{2}{*}{ Monera } & \multirow{2}{*}{ Monera } & Eubacteria & Bacteria & Eubacteria & \multirow{2}{*}{ Bacteria } & Bacteria \\
\hline & & & & & Archaebacteria & Archaea & Archaebacteria & & Arcahea \\
\hline & & \multirow{6}{*}{ Eukariota } & & & & & Archezoa & D & D \\
\hline & & & Protista & Protista & Protista & & Protozoa & Protozoa & Protozoa \\
\hline & & & $\theta$ & 80 & & & Chromista & Chromista & Chromista \\
\hline \multirow{2}{*}{ Vegetabilia } & \multirow{2}{*}{ Plantae } & & \multirow{2}{*}{ Plantae } & Fungi & Fungi & & Fungi & Fungi & Fungi \\
\hline & & & & Plantae & Plantae & & Plantae & Plantae & Plantae \\
\hline Animalia & Animalia & & Animalia & Animalia & Animalia & & Animalia & Animalia & Animalia \\
\hline
\end{tabular}




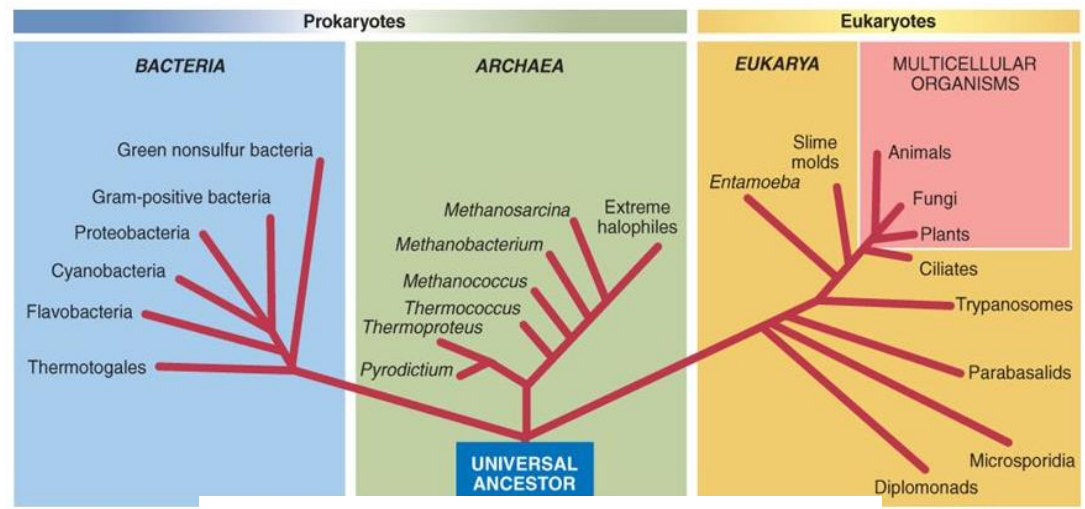

Gambar 1.5 Klasifikasi Menurut Carl Woese

\section{A). Nomenclatur Bakteri}

Seperti hewan dan tanaman, bakteri juga memiliki tata nama yang terdiri dari dua nama seperti yang diajukan oleh Linnaeus (1753) disebut dengan binomial name. Tatacara penulisan nama bakteri terdiri dari dua kata. Nama pertama menunjukkan tingkatan Genus, penulisannya pada huruf awal ditulis dengan huruf capital sedangkan nama kedua menunjukkan tingkatan spesies, penulisannya dengan huruf kecil dan dicetak miring (italic). Misalnya Escherichia coli.

Penulisan taksonomi pada bakteri seperti dibawah ini:

Kingdom/dunia: Prokaryotae

Divisi

Klas

Ordo

Famili

Genus

Spesies
: Gracillicutes

: Scotobacteria

: Eubacteriales

: Entobacteriaceae

: Escherichia

: Escherichia coli 


\subsection{Sel Prokariotik dan Eukariotik}

Berdasarkan letak DNA di dalam sel, sel pada organisme dibedakan menjadi dua yaitu sel prokariotik dan sel eukariotik.

\section{Sel Prokariotik}

Sel prokariot merupakan sel yang tidak memiliki membran inti. Materi genetik berupa DNA tidak terbungkus oleh membran dan tidak ada membran yang memisahkan DNA dengan bagian sel lainnya. DNA terletak di sitoplasma yang disebut nukleoid. Aktivitas sel berlangsung didalam sel dan didalam sitoplasma. Contoh sel prokariot adalah bakteri yang memiliki sel berukuran kecil dengan diameter sekitar 0,7-2,0 $\mu \mathrm{m}$ dan volume sekitar $1 \mu \mathrm{m}^{3}$, organisme uniseluler. Sel prokariotik memiliki ciri-ciri yang berbeda dengan sel eukariotik. Ciri-ciri tersebut antara lain:

a) Sel prokariotik memiliki sitoplasma yang bersifat difus serta bergranula karena terdapat ribosom yang melayang di sitoplasma.

b) Membran plasma yang tersusun dari dua lapis fosfolipid yang memisahkan bagian dalam sel dari lingkungannya serta berfungsi sebagai filter dan komunikasi sel.

c) Tidak mempunyai organel.

d) Memiliki dinding sel kecuali mycoplasma dan thermoplasma.

e) Kromosom berbentuk sirkuler. Sel prokariotik tidak mempunyai nukleus karena DNA tidak terselubung oleh membran.

f) Mempunyai elemen DNA ekstrakromosom yang disebut plasmid yang berbentuk sirkuler (bulat).

g) Sebagian prokariotik mempunyai flagela yang berfungsi sebagai alat gerak. 
h) Bereproduksi dengan pembelahan biner

Semua mikroorganisme memiliki ukuran beberapa mikron. Mikron $(\mu)$ atau milimikron $(\mathrm{m} \mu)$ merupakan satuan ukuran yang digunakan untuk makhluk yang sangat kecil. Perhatikan ukuran panjang dibawah ini:

- 1 meter $(\mathrm{m})=1000$ milimeter $(\mathrm{mm})$

- $1 \mathrm{~mm} \quad=1000$ mikron $(\mu)$

- $1 \mu=1000$ milimikron $(\mathrm{m} \mu)$

Setiap mikroorganisme memiliki Ukuran yang bergantung pada jenis, fase-fase pertumbuhan. Untuk mengukur menggunakan alat mikrometer dan obyek mikrometer.

\section{Sel Eukariotik}

Sel eukariot merupakan sel yang memiliki membran inti, memiliki organelle yang mempunyai fungsi yang berbeda-beda. Organel-organel pada sel eukariotik antara lain:

a) Membran sel berfungsi untuk menyeleksi keluar masuknya aliran oksigen, nutrient ke dalam sel, sintesa ATP, pensinyalan sel.

b) Mitokondria berfungsi untuk tempat metabolisme energi sel/ respirasi seluler.

c) Ribosom berfungsi sebagai tempat sistesis protein berupa proses translasi.

d) Retikulum endoplasma berfungsi untuk tempat sintesis glikoprotein dan lipid

e) Badan golgi berfungsi untuk mengarahkan hasil sintesis ke tempat tujuannya

f) Peroksisiom berfungsi untuk tenpat perombakan asam lemak dan asam amino 
g) Lisosom berfungsi menguraikan komponen sel yang rusak/benda asing yang dimasukkan oleh sel. Lisosom hanya ada pada sel hewan.

h) Vakuola berfungsi untuk tempat menyimpan nutrient dan tempat terjadinya rekasi penguraian.

i) Nucleus inti sel berfungsi untuk mengendalikan sintesis protein

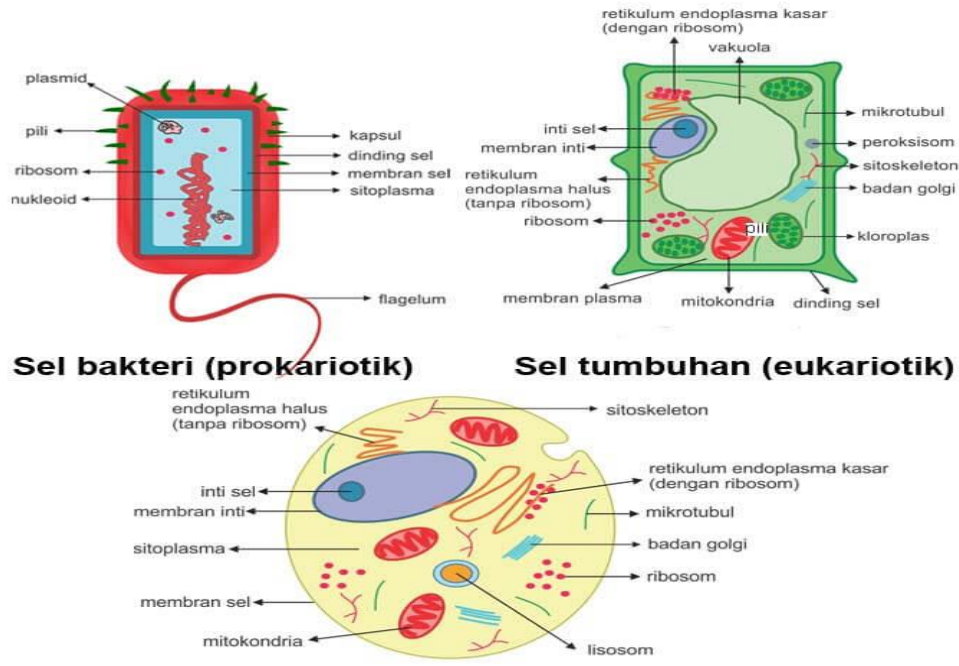

Sel hewan (eukariotik)

Gambar 1.6 Sel Prokariotik (bakteri) dan Sel Eukariotik (Tumbuhan dan Hewan)

\begin{tabular}{|c|c|c|}
\hline Ciri-ciri & Prokariotik & Eukariotik \\
\hline ukuran & $1-10 \mu \mathrm{m}$ & $10-100 \mu \mathrm{m}$ \\
\hline nukleus & $\begin{array}{c}\text { Daerah nukleosit } \\
\text { tanpa inti sejati }\end{array}$ & $\begin{array}{c}\text { Inti sejati dengan } \\
\text { membran ganda }\end{array}$ \\
\hline DNA & sirkuler & $\begin{array}{c}\text { Linear dengan } \\
\text { protein histon }\end{array}$ \\
\hline
\end{tabular}




\begin{tabular}{|c|c|c|}
\hline Sintesis RNA/protein & Di sitoplasma & $\begin{array}{l}\text { Didalam inti dan } \\
\text { sintesis protein } \\
\text { berlangsung di } \\
\text { sitoplasma }\end{array}$ \\
\hline Ribosom & $50 \mathrm{~S}$ dan $30 \mathrm{~S}$ & $60 \mathrm{~S}$ dan $40 \mathrm{~S}$ \\
\hline Struktur Sitoplasma & sederhana & Terstruktur \\
\hline Pergerakan sel & $\begin{array}{l}\text { Flagella tersusun } \\
\text { atas protein flagelin }\end{array}$ & $\begin{array}{c}\text { Flagella dan silia } \\
\text { tersusun atas } \\
\text { protein tubulin }\end{array}$ \\
\hline mitikondria & Tidak ada & ada \\
\hline Kloroplas & Tidak ada & $\begin{array}{l}\text { Pada laga dan } \\
\text { tanaman }\end{array}$ \\
\hline Pembelahan sel & biner & $\begin{array}{l}\text { Mitosis dan } \\
\text { sitokenesis }\end{array}$ \\
\hline Organisme & Bakteri dan archae & $\begin{array}{l}\text { Protista, fungi, } \\
\text { tanaman, hewan }\end{array}$ \\
\hline
\end{tabular}

\subsection{Manfaat dan Mikroorganisme}

Mikroorganisme memiliki manfaat bagi kehidupan manusia antara lain:

1. Pemanfaatan mikroba dalam proses-proses pembuatan makanan dan minuman contoh khamir untuk membuat anggur dan roti, bakteri asam laktat untuk yogurt dan kefir, bakteri asam asetat untuk vinegar, jamur Aspergillus sp. untuk kecap, dan jamur Rhizopus sp. untuk tempe.

2. Pemanfaatan mikroba untuk memproduksi antibiotik contohnya yaitu penisilin oleh jamur Penicillium sp., streptomisin oleh actinomysetes Streptomyces sp.

3. Pemanfaatan mikroba untuk proses-proses yang modern contohnya karotenoid dan steroid oleh jamur, asam glutamat 
oleh mutan Corynebacterium glutamicum, pembuatan enzim amilase, proteinase, pektinase, dan lain-lain.

4. Pemanfaatan mikroba pada teknik genetika modern seperti pemindahan gen dari manusia, binatang, atau tumbuhan ke dalam sel mikroba, penghasilan hormon, antigen, antibodi, dan senyawa lain contohnya insulin, interferon, dan lain-lain.

5. Pemanfaatan mikroba pada bidang pertanian, contohnya pupuk hayati (biofertilizer), biopestisida, pengomposan, dan sebagainya.

6. Pemanfaatan mikroba pada bidang pertambangan, seperti untuk proses leaching di tambang emas, desulfurisasi batubara, maupun untuk proses penambangan minyak bumi.

7. Pemanfaatan mikroba pada bidang lingkungan contohnya untuk mengatasi pencemaran limbah organik maupun anorganik termasuk logam berat dan senyawa xenobiotik

\section{5 Mikroorganisme Yang Merugikan}

Bakteri pathogen (berbahaya) yakni bakteri yang dapat menyebabkan penyakit pada manusia, hewan, dan tumbuhan.

a. Bentuk kokus Gram-positif: Streptococcus pyogenes penyebab nyeri tenggorokan dan demam reumatik, Streptococcus agalactiae penyebab meningitis pada neunatus dan penumonia.

b. Bentuk kokus Gram negatif: Neisseriae meningitidis penyebab meningitis dan septikemia, N. Gonorrhoeae merupakan agen penyebab uretritis. 
c. Bentuk Bacilus Gram positif: Bacillus anthracis penyebab penyakit anthraks, dan clostridia penyebab gangrene, tetanus, kolitis pseudomembranosa dan botulism.

d. Bakteri perusak makanan. Beberapa spesies pengurai dapat tumbuh pada makanan. Bakteri pengurai mengubah makanan dan mengeluarkan hasil metabolisme yang berupa toksin (racun). Mengakibatkan bahaya bagi kesehatan bila manusia mengkonsumsi makanan yang telah rusak dan mengandung racun. Misalnya: Clostridium botulinum, menghasilkan racun botulinin, sering terdapat pada makanan kalengan. Pseudomonas cocovenenans, menghasilkan asam bongkrek, terdapat pada tempe bongkrek. Leuconostoc mesenteroides, penyebab pelendiran makanan.

\section{KESIMPULAN}

Klasifikasi menurut Whittaker (1969) system klasifikasi 5 kingdom yaitu prokaryotik (monera), eukariotik uniseluler (protista), eukariotik multiseluler, multinukleat (Fungi, animalia, plantae). Sistem klasifikasi terbaru dikemukakan oleh Carl Woese yang membagi organisme menjadi 3 kingdom yaitu Archaea/Archaebacteria, eubacteria/bakteri, eucarya. sel pada organisme dibedakan menjadi dua yaitu sel prokariotik dan sel eukariotik.

\section{LATIHAN SOAL}

1. Jelaskan apa yang dimaksud dengan sel prokariotik dan sel eukariotik?

2. Jelaskan perbedaan sel prokariotik dan eukariotik!

3. Jelaskan klasifikasi menurut Carl Woese! 


\section{BAB II MORFOLOGI BAKTERI}

\section{TUJUAN INSTRUKSIONAL:}

1. Mahasiswa mengetahui tentang bakteri

2. Mahasiswa mengetahui bentuk sel bakteri

3. Mahasiswa mengetahui struktur sel bakteri

4. Mahasiswa mengetahui bakteri berdasarkan struktur dinding sel

Mikroba atau mikroorganisme adalah makhluk hidup yang ukurannya kecil. Mikroorganisme merupakan mikroba yang memilki ukuran yang kecil, sehingga sulit dilihat dengan mata biasa. Sel mikroba umumnya hanya dapat dilihat dengan alat pembesar atau mikroskop, walaupun demikian ada mikroba yang berukuran besar sehingga dapat dilihat tanpa alat pembesar. Mikroba memiliki susunan sel yang lebih sederhana dibandingkan dengan organisme tingkat tinggi. Mikroba yang ukurannya kurang dari 0,1 $\mathrm{mm}$ tidak dapat terlihat dengan mata telanjang. Mikroba memiliki ukuran yang dinyatakan dalam mikron $(\mu)$ dimana 1 mikron adalah 0,001 $\mathrm{mm}$.

Pengelompokkan mikroba telah bnayak dilakukan oleh peneliti antara lain oleh Haeckel, Whittaker, dan Woese. Haeckel mengelompokkan mikroba berdasarkan perbedaan pengorganisasian selnya yaitu dunia tumbuhan (plantae), dunia hewan (animalia) dan protista. Protista digolongkan mikroba. Protista terdiri dari algae atau ganggang, protozoa, jamur atau fungi, dan bakteri yang mempunyai sifat uniseluler, sonositik, atau multiseluler tanpa diferensiasi jaringan.

Menurut Whittaker makhluk hidup dibagi menjadi tiga tingkat perkembangan yaitu: 
1) Prokariotik ialah bakteri dan ganggang biru (Divisio Monera)

2) Eukariotik uniseluler ialah algae sel tunggal, khamir dan protozoa (Divisio Protista)

3) Eukariotik multiseluler dan multinukleat ialah Divisio Fungi, Divisio Plantae, dan Divisio Animalia.

Menurut Woese penggolongan mikroba berdasarkan susunan kimia makromolekul yang terdapat di dalam sel. Terdiri dari Arkhaebacteria, Eukaryota (Protozoa, Fungi, Tumbuhan dan Binatang), dan Eubacteria.

Setelah ditemukannya mikroskop elektron struktur halus di dalam sel hidup dapat terlihat. Menurut perkembangan selnya terdapat dua jenis yaitu :

1) Prokariota (jasad prokariotik/primitif), yaitu jasad yang perkembangan selnya belum sempurna.

2) Eukariota (jasad eukariotik), yaitu jasad yang perkembangan selnya telah sempurna.

Selain memiliki sifat seluler, ada beberapa mikroba yang memiliki sifat non seluler yaitu virus. Virus adalah parasit obligat yang berukuran sub-mikroskopik. Virus bukan berbentuk sel dan berkembang biak dengan jasad hidup lain.

\subsection{Bakteri}

Bakteri merupakan salah satu jenis mikroorganisme yang tidak bisa dilihat oleh mata langsung. Bakteri merupakan organisme yang jumlahnya paling banyak dibandingkan maklhluk hidup lain dan tersebar luas didunia. Bakteri memiliki ratusan ribu spesies yang hidup di darat, laut, udara dan tempat-tempat ekstrem. Bakteri memiliki ciri-ciri yang berbeda dengan makhluk lain antara lain:

- Organisme uniseluler (bersel satu). 
- Prokariot (tidak mempunyai membran inti sel ).

- Tidak mempunyai klorofil.

- Tubuh berukuran antara 0,12 mikron sampai ratusan mikron

- mempunyai bentuk tubuh yang beraneka seperti basil (batang), kokus (bulat), spirilum (spiral), kokobasil (bulat dan batang), dan vibrio (tanda baca koma).

- Memiliki dinding sel. Pada dinding sel bakteri tersusun atas mukopolisakarida dan peptidoglikan. Peptodoglikan terdiri dari polimer besar yang tersusun atas $\mathrm{N}$-asetil glukosamin dan $\mathrm{N}$-asetil muramat yang saling berikatan kovalen

- Hidup dengan bebas atau parasit.

- Hidup di lingkungan yang ekstrim seperti mata air panas, kawah atau gambut karena dinding selnya tidak mengandung peptidoglikan.

- Hidupnya kosmopolit diberbagai lingkungan karena dinding selnya mengandung peptidoglikan.

- Pada dinding sel bakteri tersusun atas mukopolisakarida dan peptidoglikan. Peptodoglikan terdiri dari polimer besar yang tersusun atas $\mathrm{N}$-asetil glukosamin dan $\mathrm{N}$-asetil muramat yang saling berikatan kovalen

- Bakteri mamiliki endospora yaitu kapsul yang muncul jika kondisi yang tidak menguntungkan sebagai perisai terhadap panas dan gangguan alam.

- Bakteri ada yang bergerak dengan flagella dan ada juga yang bergerak dengan berguling (tanpa flagella).

Bakteri memiliki bentuk bermacam-macam bentuk morfologi yaitu, bulat, batang dan spiral. 


\subsection{Bentuk Bakteri}

\section{a) Bakteri Bentuk Batang}

Bentuk-Bentuk Bakteri Basil

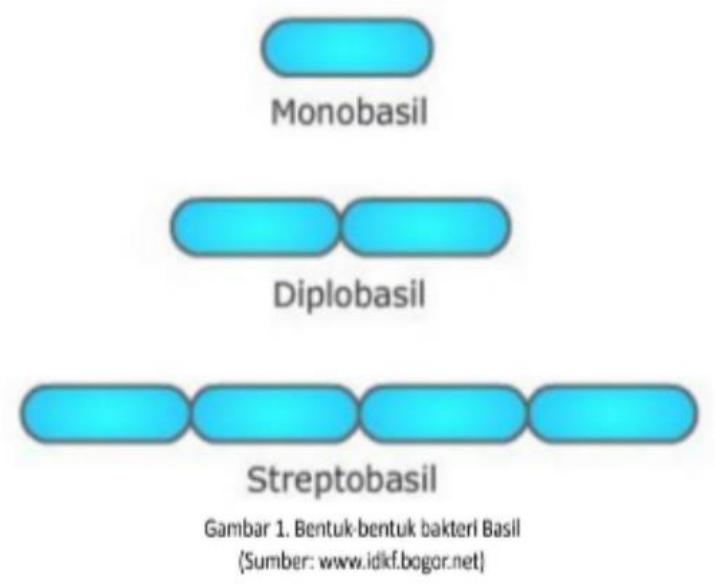

Gambar 2.1 Bentuk Bakteri Basil

Bakteri berbentuk batang dikenal sebagai basil. Kata basil berasal dari bacillus yang berarti batang. Bentuk basil dibedakan atas :

1. Basil tunggal yaitu bakteri yang hanya berbentuk satu batang tunggal, misalnya Salmonella typhi, penyebab penyakit tipus.

2. Diplobasil yaitu bakteri berbentuk batang yang bergandengan dua-dua.

3. Streptobasil yaitu bakteri berbentuk batang yang bergandengan memanjang membentuk rantai misalnya Bacillus anthracis penyebab penyakit antraks.

\section{b) Bakteri Bentuk Bulat}


Bakteri berbentuk bulat dikenal sebagai Coccus, bakteri ini dibedakan atas:

1. Monokokus, yaitu bakteri berbentuk bulat tunggal, misalnya Neisseria gonorrhoeae, penyebab penyakit kencing nanah.

2. Diplokokus, yaitu bakteri berbentuk bulat yang bergandengan dua-dua, misalnya Diplococcus pneumonia penyebab penyakit pneumonia atau radang paru-paru.

3. Sarkina, yaitu bakteri berbentuk bulat yang berkelompok empat-empat sehingga bentuknya mirip kubus.

4. Streptokokus yaitu bakteri bentuk bulat yang berkelompok memanjang rantai.

5. Stafilokokus yaitu bakteri berbentuk bulat yang berkoloni membentuk sekelompok sel tidak teratur sehingga bentuknya mirip kumpulan buah anggur. 


\section{Bentuk-Bentuk Bakteri Kokus}

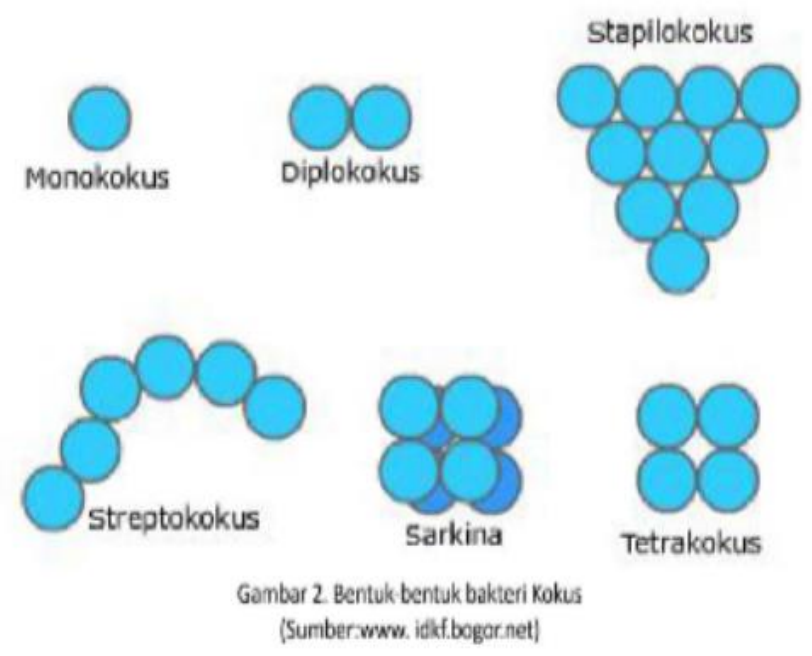

Gambar 2.2 Bentuk Bakteri coccus

\section{c) Bakteri Bentuk Spiral}

Ada tiga macam bentuk spiral :

1. Spiral, yaitu golongan bakteri yang bentuknya seperti spiral misalnya Spirillum.

2. Vibrio, ini dianggap sebagai bentuk spiral tak sempurna, misalnya Vibrio cholera penyebab penyakit kolera.

3. Spiroseta yaitu golongan bakteri berbentuk spiral yang bersifat lentur. Pada saat bergerak, tubuhnya dapat memanjang dan mengerut. 


\section{Bentuk-Bentuk Bakteri Spirilia}
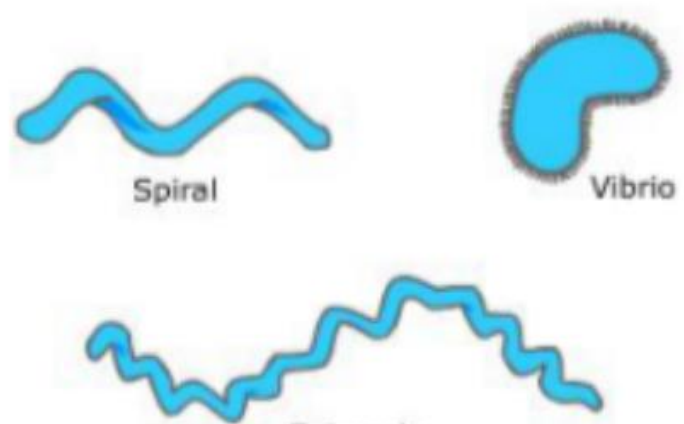

Spiroseta

Gambar 3. Bentuk-bentuk bakteri Sgirilia

(Sumber:www.eprint.walisongo.ac.id)

Gambar 2.3 Bentuk Bakteri Spiral

\subsection{Struktur Bakteri}

Berdasarkan strukurnya bakteri terbagi menjadi dua yaitu struktur dasar dan struktur tambahan. Struktur dasar meliputi dinding sel, membrane plasma, sitoplasma, ribosom, granula, DNA. Struktur tambahan meliputi kapsul, flagellum, pili, fimbria, klorosom, vakuola, endospore.

\section{Struktur Utama}

\section{a) Dinding Sel}

Dinding sel bakteri memiliki struktur yang kompleks dan agak kaku. Dinding sel bakteri menentukan bentuk bentuk sel. Meskipun tidak mengandung enzim dan tidak bersifat semipermeabel, namun dinding sel diperlukan agar sel bakteri dapat berfungsi secara normal. Dinding sel yang kaku 
memungkinkan bakteri dapat mengatasi konsentrasi osmosis yang berbeda-beda dan sitoplasma tidak mengembang melampaui batas dinding yang kaku itu. Sejauh ini diketahui bahwa ketebalan dinding sel bakteri berkisar 10-35 $\mathrm{nm}$.

$>$ Komposisi kimiawi dinding sel bakteri

Susunan dan struktur dinding sel prokariot sangat unik dan khas, serta tidak ditemukan pada sel eukariotik. Penyebab kakunya dinding sel bakteri karena kandungan peptidoglikan (PG). Peptidoglikan tersusun oleh:

(1) N-asetilglokosamin (NAG),

(2) Asam N-Asetilmuramat (NAM),

(3) Peptida yang terdiri dari asam amino: alanin, glutamat, diaminopimelat, atau lisin dan alanin.

Letak NAG ( $\mathrm{N}$-asetil glukosamin) dan NAM (N-asetil muramic) berselang-seling membentuk tulang punggung dinding sel, Pada NAM terdapat 4 asam amino. Asam amino ini membentuk ikatan silang dengan asam amino NAM lainnya.

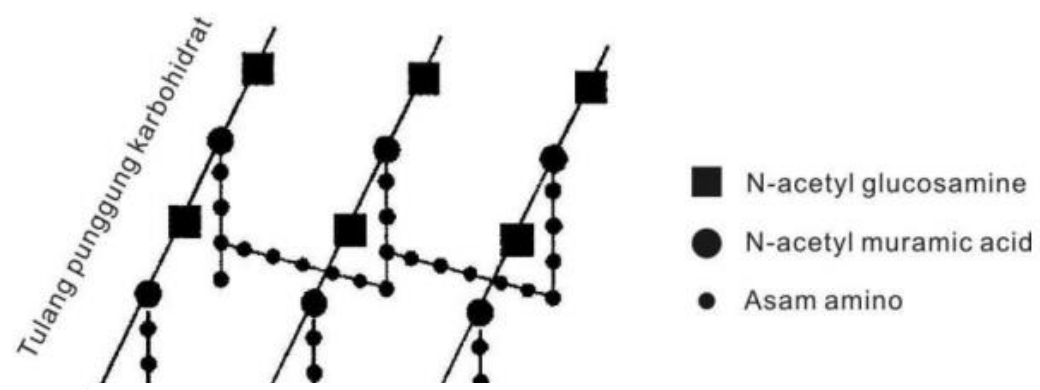

/ Gambar 2.4 Ikatan Kompenen Penyusun Peptidoglikan

Peptidoglikan disebut juga mukopeptida, glikopeptida, muropeptida atau murein peptidoglikan. Serat-serat peptidoglikan membentuk anyaman yang kuat namun tidak padat (tidak solid), 
sehingga tidak menghalangi masuknya air, zat-zat makanan, seperti mineral, glukosa, asam amino atau bahkan molekul organik.

Berdasarkan perbedaan kandungan dari dinding sel, bakteri dapat digolongkan menjadi dua yaitu bakteri Gram positif dan bakteri Gram negatif. Bakteri Gram positif dinding selnya tersusun atas PG (petidoglikan) sehingga dinding selnya kaku. Pada bagian luar PG (petidoglikan) terdapat senyawa yang disebut asam teikhoat. Bakteri Gram negatif mengandung PG (petidoglikan) dalam jumlah yang jauh lebih sedikit, akan tetapi di bagian luar PG terdapat membran luar yang tersusun atas lipoprotein dan fosfolipid serta mengandung lipopolisakarida. Karena perbedaan komposisi dinding sel ini, bakteri Gram positif dan negatif memiliki ketahanan yang berbeda. Bakteri Gram positif lebih rentan terhadap antibiotika penisilin karena antibiotika ini dapat merusak PG. Sebaliknya karena jumlah PG yang lebih banyak, bakteri Gram positif biasanya lebih tahan terhadap kerusakan mekanis. Perbedaan tersebut di atas dapat pula dilihat pada Tabel 1.

Tabel 2.1 Perbedaan Susunan Dinding Bakteri Gram Positif dan Gram Negatif

\begin{tabular}{|c|c|c|}
\hline No & Gram positif & Gram negatif \\
\hline 1 & Komponen terbesar & Terdiri dari 3 lapis: \\
\hline & adalah & 1. Lapisan dalam adalah \\
\hline & peptidoglikan(terdiri 40 & peptidooglikan $\square$ satu \\
\hline & lapis rangka dasar murein, & lapis rangka dasar \\
\hline & meliputi $30-70 \%$ berat & murein \\
\hline & kering dinding sel bakteri) & $\begin{array}{l}\text { (diaminopemelat, dan } \\
\text { tidakmengandung }\end{array}$ \\
\hline & & $\begin{array}{l}\text { lisin), dan hanya } \\
\text { meliputi }+10 \% \text { dari }\end{array}$ \\
\hline
\end{tabular}




\begin{tabular}{|c|c|c|}
\hline & & $\begin{array}{l}\text { berat kering dinding } \\
\text { sel } \\
\text { 2. Lapisan luar: } \\
\text { lipopolisakarida, dan } \\
\text { lipoprotein }\end{array}$ \\
\hline 2 & $\begin{array}{l}\text { Pada beberapa bakteri } \\
\text { terdapat asam teikoat }\end{array}$ & Tidak ada asam teikoat \\
\hline 3 & $\begin{array}{l}\text { Peptidoglikan mengalami } \\
\text { lisis oleh lisozim }\end{array}$ & $\begin{array}{l}\text { Lisozim melunakkan dinding sel, } \\
\text { deterjen mengadakan } \\
\text { disorganisasi dinding itu dengan } \\
\text { merusak lapisan lipida }\end{array}$ \\
\hline 4 & $\begin{array}{l}\text { Dinding sel tebal, } 25-30 \\
\mathrm{~nm}\end{array}$ & Dinding sel tipis, $10-15 \mathrm{~nm}$ \\
\hline 5 & $\begin{array}{l}\text { Lebih rentan terhadap } \\
\text { Penicilin }\end{array}$ & Kurang rentan \\
\hline 6 & $\begin{array}{l}\text { Menyerap pewarna dasar } \\
\text { (ex: kristal violet) sehingga } \\
\text { berwarna ungu saat } \\
\text { diwarna }\end{array}$ & $\begin{array}{l}\text { Tidak begitu menyerap } \\
\text { pewarna dasar, namu dengan } \\
\text { pewarnaan safranin (merah) }\end{array}$ \\
\hline
\end{tabular}




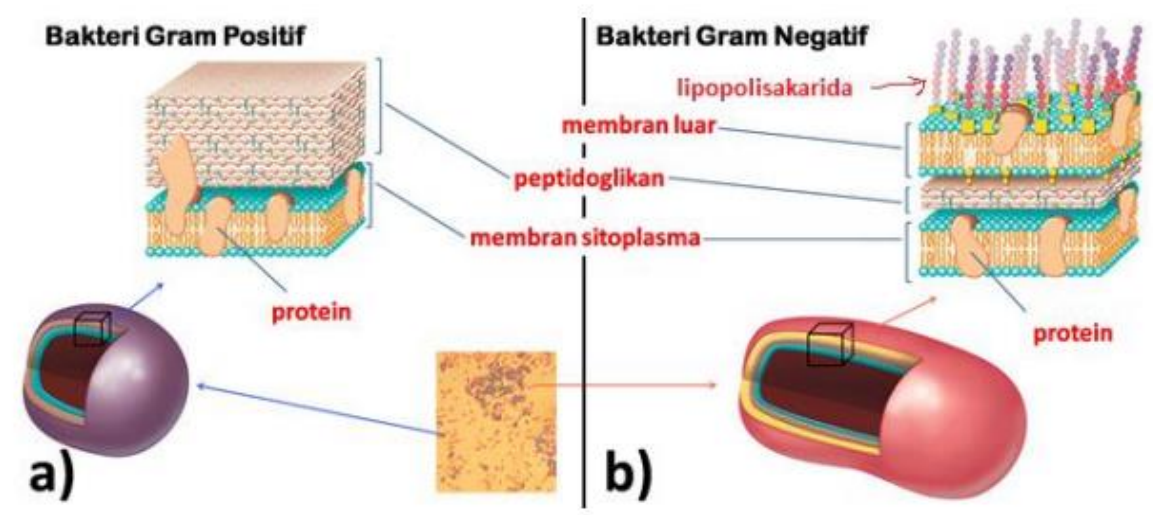

Gambar 2.1 Perbedaan Dinding (a) Sel Bakteri Gram Positif dan(b) sel Bakteri Gram Negatif

\section{b) Membran Sel}

Struktur membran sitoplasma atau membran sel berada di sebelah dalam dari dinding sel. Oleh karena itu, jika dilihat dari struktur lapisan pada sel sel bakteri, membran plasma dilindungi oleh dinding sel bakteri, yang mana sifat dinding sel bakteri yang lebih kaku jika dibandingkan dengan membran sitoplasma.

Mesosom merupakan struktur di mana membran sitoplasma yang melipat ke dalam (invaginasi) sitoplasma. Mesosom berfungsi dalam sintesis dinding sel, dan pembelahan nukleus sel bakteri.

Membran sitoplasma penting untuk mengendalikan lalu lintas substansi kimiawi dalam larutan, masuk ke dalam dan keluar sel. Susbtansi-substansi (solut) dapat melewati membran sitoplasma, dapat dengan cara sebagai berikut. 
1) Difusi pasif

Proses difusi pasif, tidak bersifat spesifik untuk setiap solut, tetapi akan terjadi jika terdapat perbedaan konsentrasi zat terlarut di luar sel dengan di dalam sel bakteri. Pada proses ini, terjadi pergerakan substansi kimia (solut) yang melintasi membran sitoplasma, dari area yang berkonsentrasi tinggi ke area yang berkonsetrasi yang lebih rendah. Difusi pasif, berfungsi untuk menyamakan konsentrasi solut di kedua sisi membran sitoplasma.

2) Transpor aktif

Proses transpor aktif bersifat sangat spesifik (memperlakukan solut secara spesifik). Transpor aktif berfungsi untuk menyimpan solut di dalam sel dengan konsentrasi yang lebih tinggi daripada di luar sel.

Membran atau selaput sitoplasma, memiliki beberapa fungsi antara lain:

$>$ Permeabilitas selektif dan pengangkutan larutan

$>$ Pengangkutan elektron dan fosforilasi oksidatif

$>$ Pengangkutan eksoenzim hidrolitik

$>$ Berlaku sebagai tempat enzim dan molekul pembawa yang berfungsi dalam biositesis DNA, polimer dinding sel dan lipid selaput.

$>$ Mengandung reseptor dan protein lain dari sistem khemotaksis.

\section{c) Sitoplasma}

\section{Nukleoid}

Sel-sel prokariot tidak memiliki nukleus sebagai tempat tersimpannya materi genetik seperti pada eukaryotik, yang ada adalah suatu daerah yang disebut nukleoid yang tidak dikelilingi 
oleh membran dan tidak mengadakan mitosis dan meiosis. Strukturnya merupakan suatu masa amorf (tak berbentuk) yang lobuler terdiri dari banyak kromatin yang fibriler.

Nukleoid terdiri dari molekul DNA yang membentuk kromosom. Molekul DNA mengandung informasi genetika dari sel bakteri. Bakteri juga mengandung DNA yang membentuk lingkaran kecil disebut plasmid. Plasmid mengandung materi genetika yang tidak penting bagi pertumbuhan sel dan bisa hilang tanpa mengakibatkan sel mati.

Fibril-fibril yang tampak pada nukleotid merupakan DNA yang panjang(sekitar $1400 \mathrm{~nm}$ ) dan tipis ( $3 \mathrm{~nm}$ ), fleksibel dan sirkuler. Filamen sirkuler DNA semacam ini pada umumnya disebut kromosom bakteri.

Pada bakteri DNA ekstrakromosom yang berbentuk cincincincin kecil, dapat berreplikasi secara autonom (tidak seirama dengan kromosom) dan dapat juga bertindak sebagai determinan genetik dinamakan episom (plasmid).

\section{Ribosom}

Ribosom merupakan tempat biosintesis protein. Ribosom terdapat baik pada sel prokariotik maupun sel eukariotik, yang berfungsi sebagai tempat sintesis protein. Ribosom disusun oleh dua subunit, setiap subunit mengandung protein dan sebuah tipe dari RNA disebut ribosomal RNA (rRNA). Ribosom prokariotik berbeda dari ribosom eukariotik dalam kandungan jumlah protein dan molekul rRNA, ribosom prokariotik juga lebih kecil dan kurang padat jika dibandingkan dengan ribosom sel eukariotik. Ribosom sel prokariotik (termasuk sel bakteri) disebut ribosom 70S, dan sel eukariotik dikenal sebagai ribosom 80S. Ribosom bakteri 70S, dari kira-kira 800.000 dalton, dipisahkan ke dalam subunit 305 dan $50 S$. Subunit $30 \mathrm{~S}$ mengandung RNA 16S, sebaliknya subunit 50S mengandung keduanya RNA $23 \mathrm{~S}$ dan $5 \mathrm{~S}$. Huruf S menujukkan unit 
Svedberg, yang menunjukkan laju relatif sedimentasi (pengendapan) selama sentrifuge kecepatan tinggi.

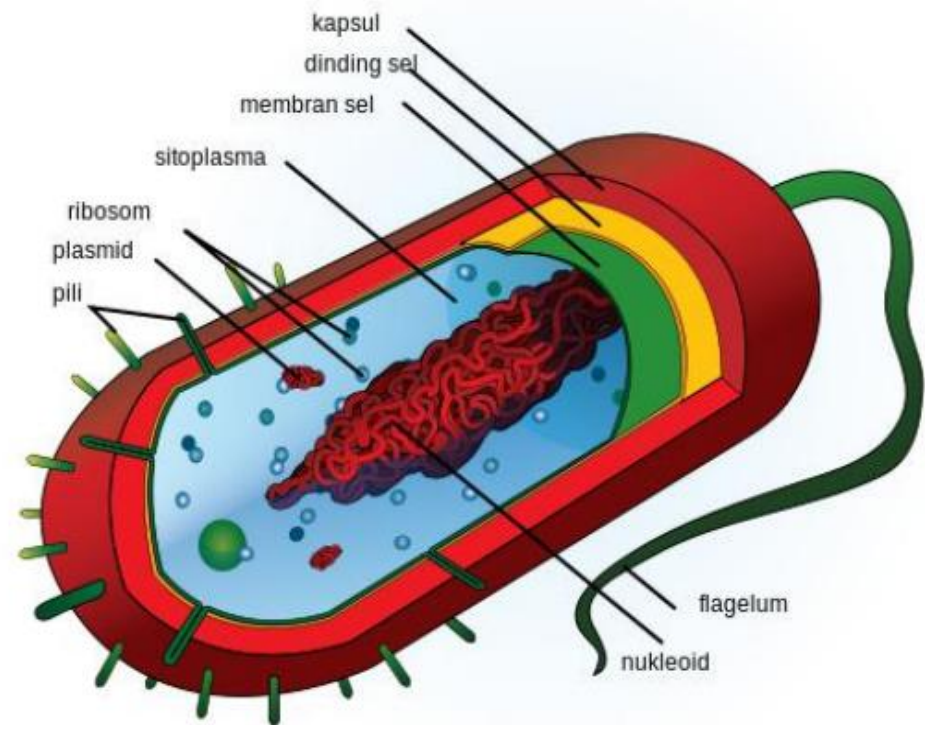

Gambar 2.2 Sel Bakteri

3. encunume

Pada sitoplasma sel prokariot terdapat granula. Granula ini berfungsi sebagai tempat menyimpan cadangan makanan karena bakteri akan menyimpan cadangan makanan yang dibutuhkan. Granula-granula tersebut mengandung bermacam-macam substansi seperti glikogen, metafosfat anorganik, asam polihidroksibutirat, belerang atau senyawa yang mengandung nitrogen yang berperan sebagai cadangan nutrisi untuk sel yang di kenal dengan nama badan inklusi. Beberapa macam inklusi tertentu terdapat pada satu spesies bakteri, sedangkan pada spesies lain tidak memilikinya. Oleh sebab itu, jenis-jenis inklusi dapat digunakan untuk mengidentifikasi spesies bakteri. 


\section{Plasmid}

Kebanyakan bakteri memiliki plasmid. Plasmid merupakan molekul DNA kecil di dalam sel yang secara fisik terpisah dari DNA kromosom dan bisa bereplikasi secara independen. Pada bakteri plasmid berfungsi sebagai pembawa sifat non-esensial bagi pertumbuhan bakteri yang berperan secara langsung dalam metabolisme dan segala kegiatan biologis yang membantu pertumbuhan bakteri.

\section{Struktur Tambahan}

\section{Flagella}

Flagella (tunggal $=$ flagellum) adalah filamen yang memanjang ke arah luar sel. Flagel merupakan alat gerak bakteri sehingga bakteri dapat bergerak dan berputar. Flagel disusun oleh sub unit-sub unit protein disebut flagelin. Ukuran flagel berdiameter $12-18 \mathrm{~nm}$ dan panjangnya lebih dari $20 \mathrm{~nm}$. flagella yang agak kaku berfungsi sebagai poros yang mendorong sel dengan cara memutar searah atau berlawanan arah dengan jarum jam. 


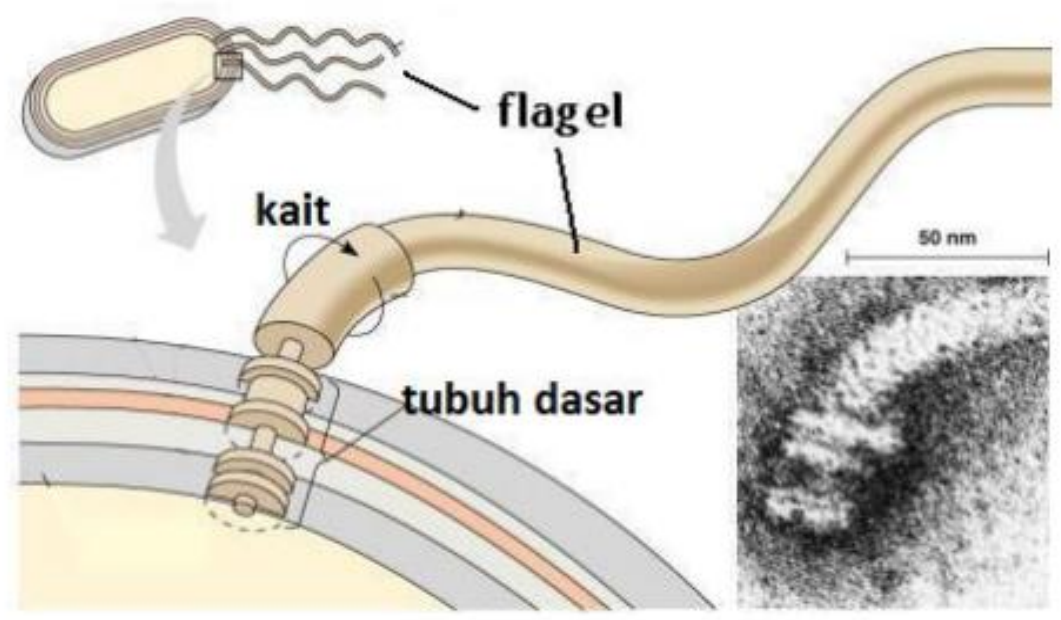

Gambar 2.3 Flagella Pada Bakteri

Berdasarkan letak dan jumlah flagel dapat dibagi menjadi:

a) Atriks ialah bakteri yang btidak memilki flagel contoh: Klebsiella sp, Shigella sp

b) Monotriks ialah bakteri yang memiliki flagel tunggal pada salah satu ujungnya contoh: Vibrio

c) Lopotriks ialah bakteri yang memiliki banyak flagella pada salah satu ujungnya contoh: Rhodospiriullum rubrum

d) Amfitrik ialah bakteri yang memiliki flagel pada kedua ujungnya contoh: Pseudomonas aeruginosa

e) Peritriks ialah bakteri yang memiliki flagel yang terletak pada seluruh permukaan sel contoh: Salmonella 


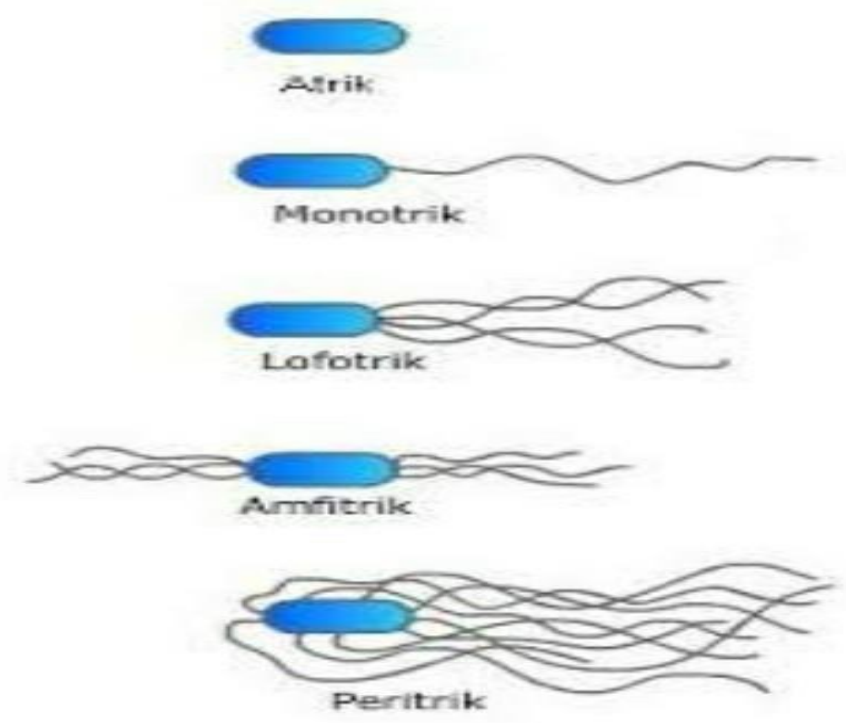

Gambar 2.4 Bentuk Flagel Bakteri

\section{Pili dan Fimbriae}

Banyak bakteri Gram negatif, memiliki apendiks mirip rambut, yang lebih pendek, lebih lurus dari flagella, dan digunakan untuk perlekatan dan transfer Deoxyribonucleic Acid (DNA) daripada untuk motilitas. Struktur ini mencakup protein, yang disebut pilin. Struktur pilin terdiri atas dua tipe yaitu pili (tunggal = pillus) dan fimbriae (tunggal = fimbria).

Fimbriae berjumlah sedikit sampai beberapa ratus buah persel bakteri. Fimbriae berperan lebih ke perlekatan antara satu sel dengan sel bakteri lain, dan ke suatu permukaan. Sedangkan Pili biasanya lebih panjang dari fimbriae dan jumlahnya hanya satu atau dua buah per sel bakteri. Pili dilibatkan dalam hal motilitas dan transfer DNA pada sel bakteri. Beberapa pili digunakan untuk membawa bakteri bersama-sama yang memungkinkan transfer DNA dari satu sel ke sel lain, yang mana proses ini dinamakan 
konjugasi. Pili yang terlibat dalam proses konjugasi dinamakan pili (seks) konjugasi.

\section{Kapsul atau Lendir}

Kapsul atau lender pada bakteri berfungsi untuk melindungi bakteri dari lingkungan luar juga sebagai tempat penyimpanan makanan. Kapsul atau selubung lendir merupakan suatu lapisan di permukaan luar sel yang terbentuk dari akumulasi senyawa-senyawa yang kaya akan air. contohnya bakteri yang memiliki kapsul terdapat pada bakteri Pneumcoccus sp.

Kapsul dapat menyebabkan timbulnya sifat virulen/ infeksi terhadap inangnya. Jika bakteri kehilangan kapsul, maka ia dapat kehilangan virulensinya.

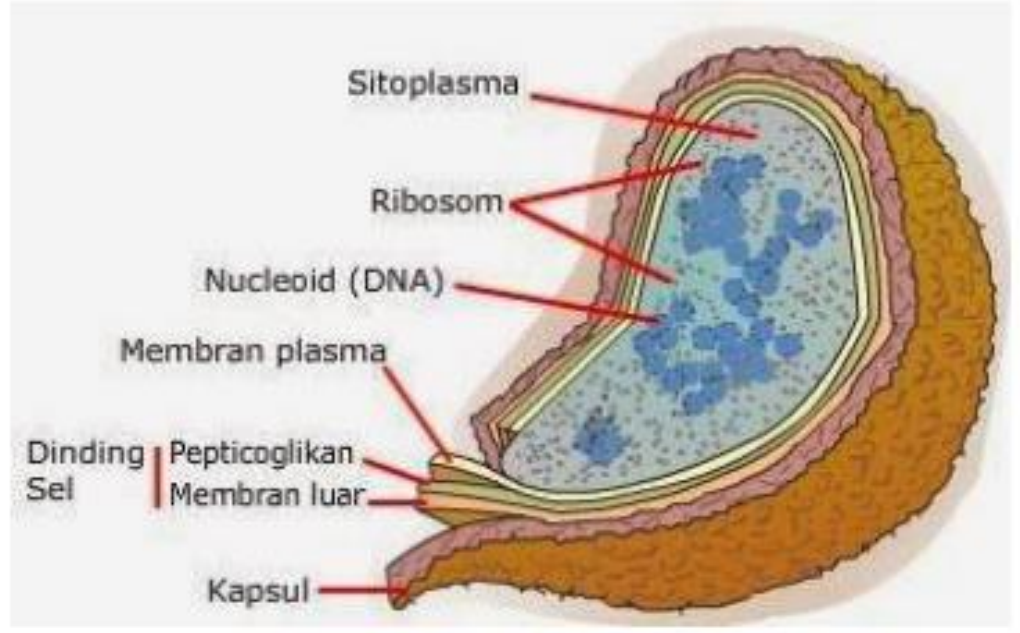

Gambar 2.5 Kapsul Pada Bakteri

Bentuk kapsul pada bakteri dapat dilihat dengan menggunakan metode pengecatan negatif memakai tinta cina atau nigrosin. Setelah diwarnai kapsul akan tampak transparan diantara background yang berwarna gelap. Kapsul tersusun atas 
polisakarida yang terdiri atas glukosa, gula amino, rhamnosa, serta asam organik seperti asam piruvat dan asam asetat. Ada pula yang mengandung peptida yaitu kapsul pada bakteri Bacillus sp.

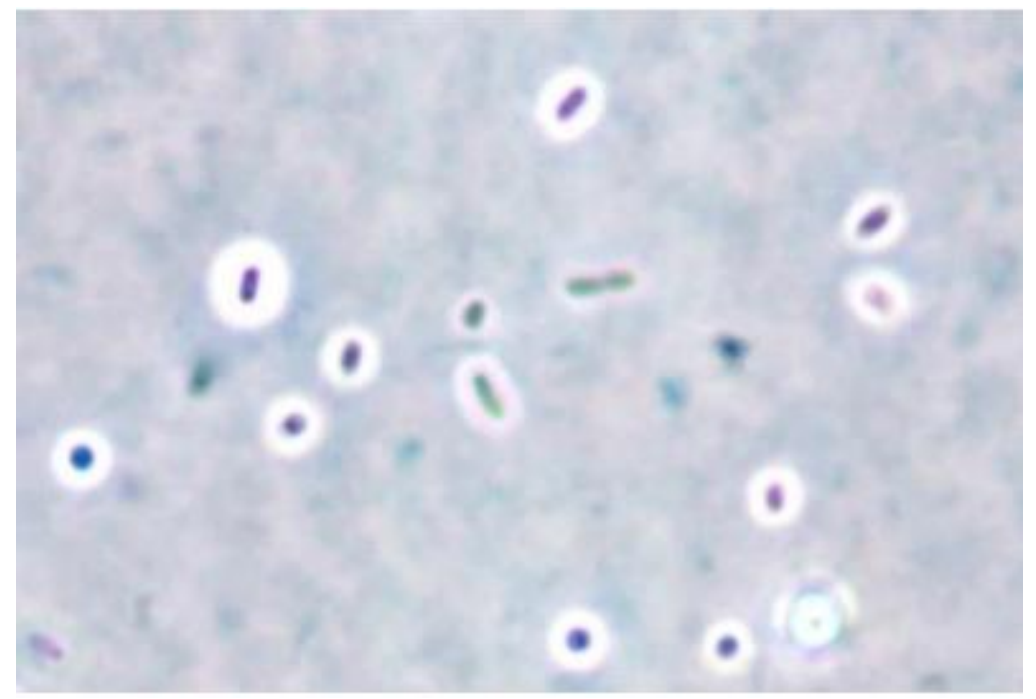

Gambar 2.6 Kapsul (berwarna putih) pada Bakteri

\section{Endospora (Spora)}

Endospora akan terbentuk bila sel bakteri berada pada kondisi lingkungan buruk seperti suhu yang tinggi, kekeringan (kadar air minim), senyawa kimia beracun (disinfektan, antibiotik) dan radiasi sinar UV. Endospora merupakan fase dimana bakteri tertentu menebalkan dinding selnya sebagai bentuk pertahanan diri dari kondisi lingkungan yang kurang menguntungkan, contoh pada Bacillus dan Clostridium.

Endospora memiliki dinding yang amat tebal jika dibandingkan dengan sel vegetatifnya, sehingga Endospora sangat sukar diwarnai dengan pewarna biasa, dan harus menggunakan 
pewarna spesifik. Pewarna yang biasa digunakan adalah malachite green.

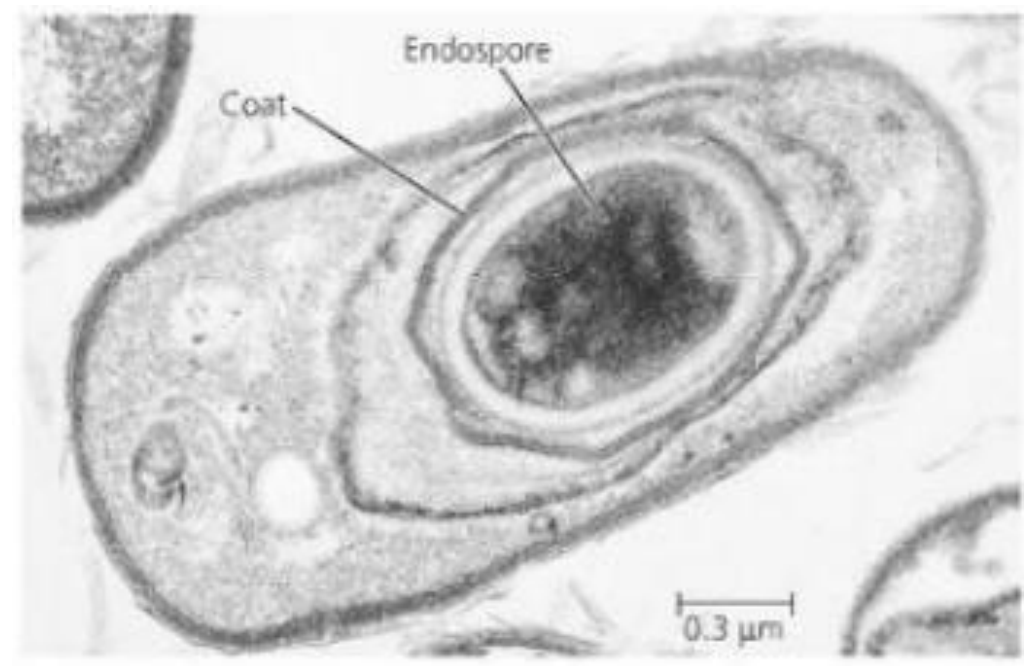

Gambar 2.7 Endospora Bakteri

\section{Vakuola}

Beberapa bakteri yang hidup di air dan dapat berfotosintesis memiliki vakuola. Vakuola berfungsi sebagai pencernaan makanan dan osmoregulaotr sel. Vakuola gas pada bakteri berfungsi untuk mengatur jumlah gas sehingga bakteri akan meningkatkan atau mengurangi kepadatan selnya secara menyeluruh serta dapat bergerak ke atas atau kebawah didalam air. Dengan adanya vakuola gas pada bakteri menyebabkan bakteri dapat mengapung dipermukaan air sehingga memperoleh sinar matahari untuk melakukan fotosintesis. 


\section{Klorosom}

Klorosom hanya terdapat pada bakteri yang melakukan fotosintesis. Klorosom berbentuk lipatan yang terletak dibawah membran plasma mengandung klorofil dan pigmen fotosintetik.

\subsection{Bakeri Berdasarkan Struktur Dinding Sel}

Berdasarkan struktur dinding selnya bakteri dibedakan menjadi dua yaitu bakteri Gram positif dan bakteri Gram negatif. Untuk mengetahui perbedaannya dapat lihat dengan pewarnaan dan diamati dibawah mikroskop. Teknik pewarnaan yang digunakan yaitu pewarnaan Gram sesuai dengan nama penemunya yaitu Hans Christian Gram (1884). Bakteri yang diwarnai dengan zat warna violet dan yodium, dicuci dengan alkohol, diwarna dengan safranin. Bila dalam pengamatan secara mikroskopis bakteri menunjukkan warna ungu maka dikelompokkan pada jenis bakteri Gram positif, bila pengamatan secara mikroskopis bakteri menunjukkan warna merah maka dikelompokkan pada jenis bakteri Gram negatif. Ada kelompok bakteri dari famili Bacillicea yang pada usia tertentu berubah dari Gram positif menjadi Gram negatif disebut Gram variabel.

\section{Ciri-ciri Bakteri Gram Positif}

a. Struktur dinding sel tebal sekitar $15-80 \mathrm{~nm}$, berlapis tunggal (monolayer)

b. Dinding sel sebagian besar tersusun dari peptidoglikan dan sebagian lagian terdiri dari polisakarida dan asam teikoat

c. Bersifat lebih rentan terhadap penisilin, tidak peka terhadap streptomisin

d. Lebih resisten terhadap gangguan fisik

e. Toksin yang dibentuk berupa eksotoksin dan endotoksin 
Tabel 2.2 Bakteri Gram Positif

\begin{tabular}{|l|l|l|}
\hline Bakteri & \multicolumn{1}{|c|}{ Genus } & \multicolumn{1}{c|}{ Penyakit } \\
\hline \multirow{2}{*}{ Gram positif } & Staphylococcus & $\begin{array}{l}\text { Bronchitis, keracunan } \\
\text { makanan }\end{array}$ \\
\cline { 2 - 3 } & Streptococcus & $\begin{array}{l}\text { Radang } \\
\text { meningitis }\end{array}$ \\
\cline { 2 - 3 } & Enterococcus & enteritis \\
\cline { 2 - 3 } & Listeria & listeriosis \\
\cline { 2 - 3 } & Bacillus & antrax \\
\cline { 2 - 3 } & Clostridium & tetanus \\
\cline { 2 - 3 } & Mycobacterium & TBC \\
\hline
\end{tabular}

\section{Ciri-ciri Bakteri Gram Negatif}

a. Komposisi dinding sel yang tipis sekitar 10-15 nm terdiri dari kandungan lipid yang tinggi dan peptidoglikan

b. Memiliki membrane plasma ganda yang diselimuti oleh membrane luar permeabel

c. Lebih tahan atau kuat terhadap antibiotik

d. Tidak memilliki asam teikoat

e. Toksin yang dibentuk endotoksin

Tabel 2.3 Bakteri Gram Negatif

\begin{tabular}{|c|l|l|}
\hline Bakteri & \multicolumn{1}{|c|}{ Genus } & \multicolumn{1}{c|}{ Penyakit } \\
\hline \multirow{3}{*}{ Gram negatif } & Salmonella & salmonelosis \\
\cline { 2 - 3 } & Escherichia & gastroenteritis \\
\cline { 2 - 3 } & Shigella & disentri \\
\cline { 2 - 3 } & Neisseria & meningitis \\
\hline
\end{tabular}




\begin{tabular}{|l|l|l|}
\hline & Pseudomonas & Luka bakar \\
\cline { 2 - 3 } & Vibrio & kolera \\
\cline { 2 - 3 } & Treponema & sifilis \\
\hline
\end{tabular}

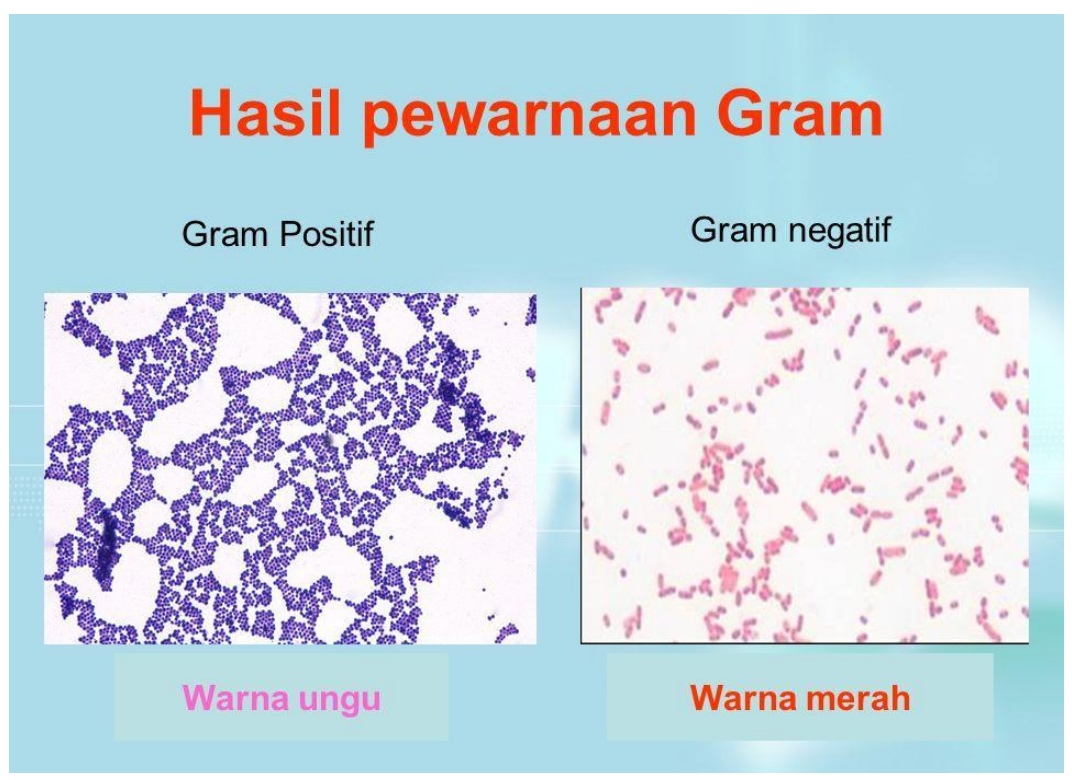

Gambar 2.8 Pewarnaan Bakteri Gram Positif dan Bakteri Gram Negatif

Dari penjelasan diatas dapat diketahui persamaan dan perbedaan antara bakteri Gram positif dan bakteri Gram negatif.

\subsection{Persamaan dan Perbedaan Bakteri Gram Positif dan Bakteri Gram Negatif}

A. Persamaan Bakteri Gram Positif dan Bakteri Gram Negatif

- Bakteri Gram Positif dan Gram Negatif memiliki organisasi seluler yang serupa merupakan mikroorganisme uniseluler prokariotik yang memiliki kapsul. 
- Memiliki kromosom tunggal.

- Mengandung plasmid sebagai DNA ekstrachromosomalnya.

- Bereproduksi secara aseksual dengan pembelahan biner.

- Bereproduksi juga dengan transformasi, transduksi dan konjugasi.

- Dapat dihambat oleh antibiotik.

- Dinding sel mengandung peptidoglikan.

- Dapat merespons prosedur pewarnaan gram. $S$

- Dapat menyebabkan penyakit pada manusia, tumbuhan dan hewan.

B. Perbedaan Bakteri Gram Positif dan Bakteri Gram Negatif

Tabel 2.4 Perbedaan Bakteri Gram Positif dan Bakteri Gram Negatif

\begin{tabular}{|c|c|c|}
\hline Perbedaan & Bakteri Gram Positif & $\begin{array}{c}\text { Bakteri Gram } \\
\text { negatif }\end{array}$ \\
\hline $\begin{array}{c}\text { Lapisan } \\
\text { peptidoglikan }\end{array}$ & Lebih tebal 1-4\% & $\begin{array}{c}\text { Lebih tipis 11- } \\
22 \%\end{array}$ \\
\hline $\begin{array}{c}\text { Toksin yang } \\
\text { dibentuk }\end{array}$ & Eksotoksin & Endotoksin \\
\hline Bentuk sel & Bulat, batang, filamen & $\begin{array}{c}\text { Bulat, oval, } \\
\text { koma }\end{array}$ \\
\hline Metabolisme & kemoorganohetetrotrof & fototrof \\
\hline Motilitas & $\begin{array}{c}\text { Non motil bila motil } \\
\text { tipe flagella adalah } \\
\text { petritikus }\end{array}$ & $\begin{array}{c}\text { Motil dan non } \\
\text { motil, flagella } \\
\text { bervariasi }\end{array}$ \\
\hline Endospore & $\begin{array}{c}\text { Beberapa kelompok } \\
\text { membentuk endospora }\end{array}$ & $\begin{array}{c}\text { Tidak } \\
\text { membentuk } \\
\text { endospore }\end{array}$ \\
\hline
\end{tabular}




\section{KESIMPULAN}

Berdasarkan perkembangan selnya terdapat dua tipe mahkluk hidup yaitu prokariotik dan eukariotik.

Morfologi sel bakteri berdasarkan bentuknya yaitu bulat, batang, spiral. Berdasarkan strukturnya terbagi menjadi dua yaitu struktur dasar meliputi dinding sel, membran plasma, sitoplasma, ribosom, granula, DNA. Struktur tambahan meliputi kapsul, flagellum, pili, fimbria, klorosom, vakuola, endospore. Berdasarkan komponen penyusun dinding sel, maka bakteri dapat dikelompokkan menjadi bakteri Gram positif yang memiliki satu lapisan tunggal peptidoglikan dan bakteri Gram negatif yang memiliki tiga lapisan yaitu membran luar, dinding sel dan membran plasma. Peptidoglikan merupkan komponen utama dari bakteri Gram posistif, sedangkan lipid merupakan komponen terbesar penyusun bakteri Gram negatif.

\section{LATIHAN SOAL}

1. Jelaskan beberapa perbedaan dinding sel bakteri Gram positif dan negatif!

2. Sebutkan bentuk-bentuk sel bakteri dan berikan contohnya!

3. Jelaskan Mengenai Struktur utama bakteri! 


\section{BAB III PERTUMBUHAN BAKTERI}

\section{TUJUAN INSTRUKSIONAL:}

1. Mahasiswa mengetahui pertumbuhan bakteri (faktor-faktor pertumbuhan, nutrisi pertumbuhan)

2. Mahasiswa mengetahui kurva pertumbuhan bakteri

3. Mahasiswa mengetahui pengendalian pertumbuhan

4. Mahasiswa mengetahui reproduksi bakteri

\subsection{Pertumbuhan Bakteri}

Pertumbuhan merupakan proses bertambahnya ukuran atau subtansi atau masa zat suatu organisme, manusia dapat disebut tumbuh apabila bertambah tinggi, besar atau berat. Sedangkan pada organisme bersel satu pertumbuhan didefinisikan sebagai pertumbuhan koloni yakni jumlah koloni yang bertambah, ukuran koloni yang semakin besar, masssa mikroba dalam koloni semakin banyak. Definis dari Pertumbuhan mikroba yaitu pertambahan jumlah sel pada mikroba tersebut. Definisi koloni yaitu kumpulan dari beberapa mikroba yang mempunyai persamaan sifat seperti bentuk, susunan permukaan.

Faktor lingkungan dapat mempengaruhi pertumbuhan mikroba. Segala perubahan lingkungan dapat mempengaruhi morfologi dan fisiologi mikroba. Pertumbuhan mikroorganisme dipengaruhi oleh banyak faktor, baik faktor biotik maupun faktor abiotik. Faktor biotik ada yang dari dalam dan ada faktor biotik dari lingkungan. Faktor biotik dari dalam menyangkut bentuk mikroorganisme, sifat mikroorganisme dalam merespon perubahan lingkungan, kemampuan menyesuaikan diri (adaptasi). lingkungan biotik berhubungan dengan keberadaan organisme lain didalam lingkungan hidup mikroorganisme yang bersangkutan. Faktor abiotik meliputi susunan dan jumlah senyawa yang 
dibutuhkan di dalam medium kultur, lingkungan fisik (suhu, kelembaban, cahaya), keberadaan senyawa-senyawa lain yang dapat bersifat toksik, penghambat, atau pemacu, baik yang berasal dari lingkungaan maupun yang dihasilkan sendiri. Faktor lingkungan tersebut antara lain:

\section{Suhu/temperatur}

Suhu merupakan salah satu faktor penting di dalam mempengaruhi dan pertumbuhan mikroorganisme. Setiap bakteri memiliki temperatur optimal dimana mereka dapat tumbuh sangat cepat dan memiliki rentang temperatur dimana mereka dapat tumbuh. Suhu untuk pertumbuhan terdiri atas suhu minimum, suhu optimum, dan suhu maksimum. Suhu minimum yaitu suhu terendah tetapi mikroba masih dapat hidup. Suhu optimum yaitu suhu paling baik untuk pertumbuhan mikroba. Suhu maksimum yaitu suhu tertinggi untuk kehidupan mikroba. Berdasarkan rentang temperatur dimana dapat terjadi pertumbuhan, bakteri dikelompokkan menjadi tiga:

a. Psikrofilik, mikroba yang dapat hidup pada suhu dingin $-5^{\circ} \mathrm{C}$ sampai $30^{\circ} \mathrm{C}$ dan dapat tumbuh paling baik pada suhu optimum $10^{\circ} \mathrm{C}-20^{\circ} \mathrm{C}$;

b. Mesofilik, mikroba dapat hidup maksimal pada suhu $10^{\circ} \mathrm{C}-45^{\circ} \mathrm{C}$, dan suhu optimum pada $20^{\circ} \mathrm{C}$ $40^{\circ} \mathrm{C}$

c. Termofilik mikroba yang tumbuh dengan baik pada suhu $25^{\circ} \mathrm{C}-80^{\circ} \mathrm{C}$, tumbuh optimum pada $50^{\circ} \mathrm{C}-60^{\circ} \mathrm{C}$.

Suhu optimal merupakan suhu yang biasanya menggambarkan lingkungan normal mikroorganisme. Bakteri patogen/ berbahaya pada manusia akan tumbuh baik pada temperatur $37^{\circ} \mathrm{C}$. 


\section{2. pH}

$\mathrm{pH}$ medium biakan mempengaruhi kecepatan pertumbuhan, untuk pertumbuhan bakteri juga terdapat rentang $\mathrm{pH}$ dan $\mathrm{pH}$ optimal. Pada bakteri patogen $\mathrm{pH}$ optimalnya 7,2 - 7,6. Meskipun medium pada awalnya dikondisikan dengan $\mathrm{pH}$ yang dibutuhkan untuk pertumbuhan tetapi, secara bertahap besarnya pertumbuhan akan dibatasi oleh produk metabolit yang dihasilkan mikroorganisme tersebut.
a. Asidofil, tumbuh pada kisaran $\mathrm{pH} 2-5$
b. Neutrofil, tumbuh pada kisaran $\mathrm{pH}$ 5,5-8
c. alkalofil, tumbuh pada kisaran $\mathrm{pH} 8,4-9,5$

\section{Kelembaban}

Mikroorganisme mempunyai nilai kelembaban optimum. Mikroba dapat tumbuh pada media yang basah dan udara lembab. Nilai kadar air bebas didalam larutan untuk bakteri pada umumnya antara 0,90 sampai 0, 999 .

\section{Ketersediaan Oksigen}

Berdasarkan kebutuhan oksigennya mikroba dikelompokkan menjadi:

a) Aerobik : hanya dapat tumbuh apabila ada oksigen bebas.

(b) Anaerob : hanya dapat tumbuh apabila tidak ada oksigen bebas.

(c) Anaerob fakultatif : dapat tumbuh baik dengan atau tanpa oksigen bebas.

(d) Mikroaerofilik : dapat tumbuh apabila ada oksigen dalam jumlah kecil.

\section{Tekanan Osmosis}

Tekanan osmosis sangat mempengaruhi bakteri. Jika tekanan osmosis lingkungan lebih besar (hipertonis) sel akan mengalami 
plasmolisis (keluarnya cairan dari sel bakteri melalui membran sitoplasma). Jika tekanan osmosis lingkungan hipotonis akan menyebabkan sel membengkak serta mengakibatkan rusaknya sel. Oleh karena itu, dalam mempertahankan hidupnya sel bakteri harus berada pada tingkat tekanan osmosis yang sesuai walaupun sel bakteri memiliki daya adaptasi, perbedaan tekanan osmosis dengan lingkungannya tidak boleh terlalu besar.

Berdasarkan tekanan osmosis yang dibutuhkan dapat dikelompokkan menjadi:

(a) mikroba osmofil adalah mikroba yang dapat tumbuh pada kadar gula tinggi

(b) mikroba halofil adalah mikroba yang dapat tumbuh pada kadar garam halogen yang tinggi

(c) mikroba halodurik adalah kelompok mikroba yang dapat tahan (tidak mati) tetapi tidak dapat tumbuh pada kadar garam tinggi, kadar garamnya dapat mencapai $30 \%$.

\section{Nutrisi}

Nutrisi diperlukan oleh mikroba untuk sebagai sumber energi dan pertumbuhan selnya. Unsur-unsur dasar tersebut adalah : karbon, nitrogen, hidrogen, oksigen, sulfur, fosfor, zat besi dan sejumlah kecil logam lainnya. Kekurangan sumber-sumber nutrisi ini dapat mempengaruhi pertumbuhan mikroba hingga pada akhirnya dapat menyebabkan kematian. Berdasarkan sumber karbon dan energi yang diperlukan bakteri digolongkan menjadi :

a. Khemoheterotrof : bakteri yang memerlukan bahanbahan organik seperti protein, karbohidrat dan lipid.

b. Khemoautotrof : Golongan bakteri yang sebagian sumber karbonnya berasal dari $\mathrm{CO}_{2}$.

c. Fototrof : Golongan bakteri yang memerlukan sumber karbon yang seluruhnya dari $\mathrm{CO}_{2}$. 
Berdasarkan Sumber Nitrogen, Sulfur dan Fosfor. Untuk menyusun bagian-bagian sel, misalnya untuk mensintesis protein diperlukan nitrogen dan sulfur sedangkan untuk mensintesis DNA dan RNA diperlukan nitrogen dan fosfor.

\section{Ion-Ion lain}

Untuk pertumbuhannya bakteri membutuhkan unsurunsur kimia seperti $\mathrm{C}, \mathrm{H}, \mathrm{N}, \mathrm{S}$, dan $\mathrm{P}$. selain itu juga membutuhkan unsur mikro seperti, $\mathrm{Zn}, \mathrm{Fe}$, dan $\mathrm{Cu}$. Sedangkan logam berat seperti $\mathrm{Hg}, \mathrm{Ag}, \mathrm{Cu}, \mathrm{Au}$, dan $\mathrm{Pb}$ pada kadar rendah dapat bersifat meracun (toksin). Logam berat memiliki daya oligodinamik yaitu daya bunuh logam berat pada kadar rendah. Selain logam berat ada juga ion-ion lain yang dapat mempengaruhi kegiatan fisiologi mikroba antara lain ion sulfat, tartrat, klorida, nitrat, dan benzoat. Ion-ion ini dapat mengurangi pertumbuhan mikroba tertentu. Oleh sebab itu ion-ion ini dapat digunakan untuk mengawetkan suatu bahan. Ada senyawa lain yang dapat mempengaruhi fisiologi mikroba, misalnya asam benzoat, asam asetat, dan asam sorbat.

\section{Radiasi}

Radiasi yang berbahaya bagi mikroorganisme yaitu radiasi pengionisasi yang memiliki arti radiasi dari gelombang panjang yang sangat pendek dan berenergi sehingga atom kehilangan elektron (ionisasi). Ditingkat rendah radiasi pengionisasi dapat menyebabkan mutasi dan lama-kelamaan dapat menyebabkan kematian.

\subsection{Kurva Pertumbuhan Bakteri}

Proses tahapan pertumbuhan mikroorganisme dari awal pertumbuhan hingga kematian di gambarkan dengan kurva pertumbuhan. Tahapan pertumbuhan bakteri terdiri atas empat 
fase antara lain fase lag, fase eksponensia, fase stasioner, fase kematian.

a. Fase lag

Dinamakan juga fase adaptasi. Pada fase ini perubahan bentuk dan pertumbuhan jumlah individu belum terlihat jelas. Mikroba beradaptasi untuk menyesuaikan diri dengan substrat dan kondisi lingkungan sekitar. Waktu yang dibutuhkan untuk beradaptasi sekitar 5 menit hingga berjam-jam. Pada fase ini belum atau tidak ada sumber nutrien untuk mikroba, belum terjadi pembelahan sel karena enzim belum disintesis. Waktu yang diperlukan untuk beradaptasi lama karena dipengaruhi oleh beberapa faktor- faktor antara lain:

a) Jumlah inokulum

Bila jumlah sel yang dipindahkan banyak maka fase lag akan berjalan dengan cepat, tetapi bila jumlah sel yang dipindahkan sedikit maka fase lag akan berjalam lambat. Lama waktu mikroba beradaptasi disebabkan karena mikroba dipindahkan dari medium yang kaya nutrisi ke medium yang nutrsinya terbatas.

b) Lingkungan pertumbuhan

Bila mikroba dipindahkan dari medium dan lingkungan yang sama seperti sebelumnya maka waktu adaptasi yang diperlukan akan cepat tetapi bila medium dan lingkungan yang baru berbeda dengan medium dan lingkungan sebelumnya maka membutuhkan waktu beradaptasi yang lama.

b. Fase logaritmik/eksponensial

Pada fase ini mulai terjadi perubahan bentuk, pembelahan sel dengan cepat dan peningkatan jumlah sel secara maksimum. Peningkatan ini dipengaruhi oleh beberapa faktor yaitu 
kandungan sumber nutrien sebagai bahan makan untuk mikroba. Apabila tidak ada kandungan nutrien yang cukup maka mikroba tidak dapat berkembang biak, suhu dan kelembaban udara, kadar oksigen, cahaya, asosiasi kehidupan diantara mikroba. Fase ini membutuhakan energi yang lebih banyak dibandingkan dengan fase lainnya.

c. Fase Stasioner

Fase stasioner merupakan fase keseimbangan antara pertumbuhan dan kematian sel. Pada fase ini sumber nutrien mulai berkurang. Mikroba tidak bisa melakukan aktivitas pertumbuhannya karena nutrien untuk mikroba mulai habis sehingga akan terbentuk produk-produk beracun yang dapat mengakibatkan pertumbuhan sel melambat sehingga jumlah sel hidup seimbang dengan jumlah sel yang mati. Kapadatan bakteri pada fase ini mencapai kepadatan sel yang maksimal. Selain itu pada fase ini ukuran sel lebih kecil hal ini disebabkan sel tetap tumbuh walaupun nutrien mulai habis.

d. Fase Kematian

Pada fase ini nutrien sudah habis, energi cadangan didalam sel habis, proses metabolisme berhenti, laju kematian meningkat dan ada kemungkinan sel - sel dihancurkan oleh pengaruh enzim yang berasal dari sel itu sendiri (autolisis) sehingga mikroba tidak mampu lagi bertahan hidup dan mengalami kematian. 


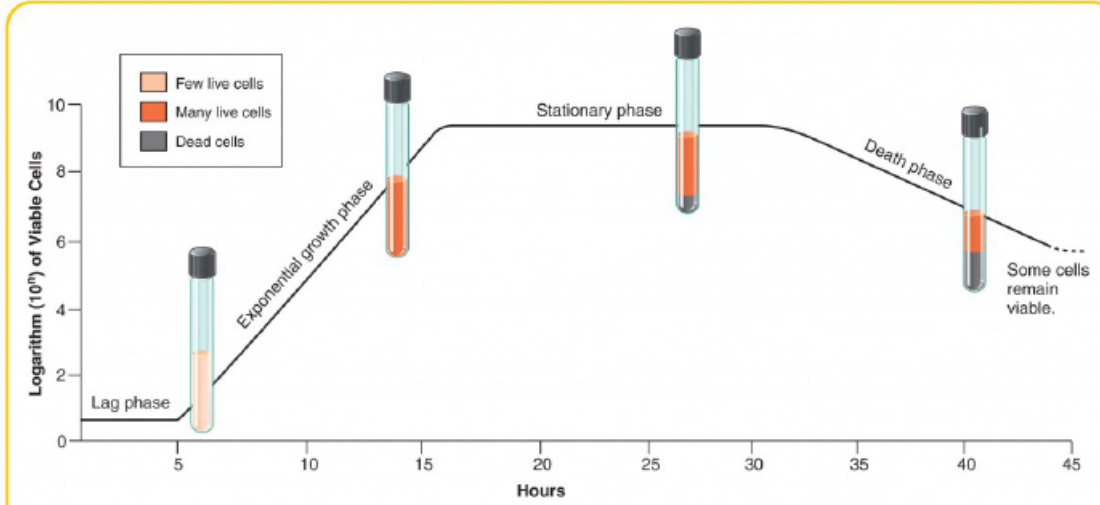

Total cells in population, live and dead, at each phase.

Gambar 3.1 Kurva Pertumbuhan Bakteri

\subsection{Pengendalian Pertumbuhan Mikroorganisme}

Mikroba selain dapat menguntungkan juga dapat merugikan manusia yang berupa penyalit atau racun. Upaya agar memanfaatkan mikroba yang menguntungkan manusia lebih optimal maka dilakukan pengendalian mikroba. Pengendalian pertumbuhan mikroba bertujuan untuk mencegah penyebaran infeksi atau penyakit, mencegah kerusakan bahan oleh mikroba, menghambat pertumbuhan bakteri dan mencegah kontaminasi bakteri yang tiak dikehendaki pada suatu media Pertumbuhan bakteri. Secara umum cara mencegah pertumbuhan mikroorganisme ada dua prinsip yaitu:

1) Membunuh mikroorganisme

2) Menghambat pertumbuhan mikroorganisme.

Cara pengendalian mikroba dapat dilakukan dengan: 
1) Cleaning dan Sanitasi

Untuk menurunkan jumlah populasi bakteri disuatu tempat. Dengan cleaning dan sanitasi yang baik maka mikroba tidak akan tumbuh bahkan dapat membunuh mikroba karena sumber nutrisi tidak tersedia.

2) Sterilisasi

Proses untuk menghilangkan semua mikroba patogen hingga menjadi steril secara fisik dan kimiawi.

3) Desinfeksi

Merupakan proses mengurangi mayoritas atau semua mikroorganisme yang patogen kecuali spora bakteri yang terdapat pada permukaan benda-benda mati (non-biologis, seperti pakaian, lantai, dinding) secara fisik dan kimiawi.

4) Antiseptis

Senyawa kimia yang berfungsi menghambat atau memperlambat pertumbuhan mikroorganisme yang digunakan pada tubuh.

Pada bakteri pengendaliannya dapat dilakukan secara kimia maupun fisik.

A. Pengendalian Mikroorganisme Secara Kimia

Pengendalian mikroba secara kimia dapat dilakukan menggunakan bahan kimia yang berguna untuk membunuh atau mengurangi jumlah mikroorganisme yang patogen. Secara kimia pengendalian mikroorganisme lebih efektif digunakan pada sel vegetatif bakteri, virus dan fungi, tetapi tidak efektif bila digunkan untuk menghancurkan bakteri dalam bentuk endospora. Tidak ada bahan kimia yang ideal yang bisa dimanfaatkan untuk segala macam kebutuhan, ada beberapa hal yang dapat diperhatikan dalam memilih dan menggunakan senyawa kimia untuk tujuan tertentu antara lain : 
a. Aktivitas antimikroba

Mempunyai kemampuan untuk mematikan mikroorganisme dalam konsentrasi yang rendah pada spektrum yang luas yang artinya dapat membunuh berbagai macam mikroorganisme.

b. Kelarutan

artinya senyawayang digunakan dapat larut dalam air atau pelarut lain, sampai pada taraf yang diperlukan secara efektif.

c. Stabilitas

artinya memiliki stabilitas yang tinggi bila dibiarkan dalam waktu yang relatif lama dan tidak boleh kehilangan sifat antimikrobanya.

d. Tidak bersifat toksik/racun bagi manusia ataupun binatang lain artinya senyawa ini bersifat letal bagi mikroorganisme dan tidak berbahaya bagi manusia maupun hewan lain.

e. Homogenitas

komposisinya harus selalu sama sehingga bahan aktifnya sama pada setiap diaplikasikan.

f. Ketersediaan dan biaya senyawa tersebut harus tersedia dalam jumlah besar dengan harga yang terjangkau.

g. Sifat bahan sesuai kegunaan

yakni zat kimia yang digunakan untuk disinfeksi alat-alat yang terkontaminasi tidak boleh digunakan untuk kulit karena dapat merusak sel kulit.

h. Tipe mikroorganisme

Tidak semua mikroorganisme rentan terhadap mikrobiostatik atau mikrobiosida oleh sebab itu 
harus ditentukan tipe mikroorganisme yang akan dibasmi.

i. Keadaan lingkungan

Bahan yang digunakan harus aman bagi lingkungan sekitar dan tidak memiliki efek samping.

Bahan-bahan kimia dalam membunuh atau menghambat pertumbuhan mikroba bervariasi dan kompleks. Cara kerja bahan-bahan kimia ini dapat dibagi menjadi:

1. Merusak membran sel mikroba.

Meliputi golongan Surfaktans (Surface Active Agents) yakni golongan anionik, kationik dan nonionik.

2. Merusak enzim mikroba.

a. Golongan logam berat seperti arsen, perak, merkuri, dsb.

b. Golongan oksidator seperti golongan halogen, peroksida hidrogen dan formaldehid.

3. Mendenaturasi protein

Bahan kimia yang dapat menyebabkan terjadinya koagulasi dan presipitasi protoplasma seperti alkohol, gliserol dan bahan-bahan asam dan alkalis.

Efektivitas bahan-bahan kimia yang digunakan dipengaruhi oleh beberapa faktor. faktor-faktor yang mempengaruhi efektivitas bahan kimia di dalam mengendalikan mikroba antara lain:

1. Konsentrasi agen kimia yang digunakan.

Semakin tinggi konsentrasinya maka efektivitasnya semakin meningkat.

2. Waktu kontak. 
Semakin lama bahan tersebut kontak dengan bahan yang disterilkan maka hasilnya akan semakin baik.

3. Sifat dan jenis mikroba.

Mikroba yang berkapsul dan berspora lebih resisten dibandingkan yang tidak berkapsul dan tidak berspora.

4. Adanya bahan organik dan ekstra. Adanya bahan-bahan organik dapat menurunkan efektivitas agen kimia.

5. $\mathrm{pH}$ atau derajat keasaman.

Efektivitas bahan kimia dapat berubah seiring dengan perubahan $\mathrm{pH}$. Hanya ada beberapa zat bahan kimia secara hukum diterima untuk digunakan dalam pengawetan makanan. Diantaranya yang paling efektif adalah asam benzoat, sorbat, asetat, laktat dan propionat, kesemuanya ini adalah asam organic. Asam sorbet dan propionat digunakan untuk menghambat pertumbuhan kapang pada roti. Nitrat dan nitrit digunakan untuk mengawetkan daging terutama untuk mengawetkan warna dan bersifat menghambat pertumbuhan beberpa bakteri anaerobic, terutama clostridium botulinum.

B. Pengendalian Mikroorganisme Secara Fisik

Bakteri-bakteri yang patogen secara fisik memiliki keterbatasan toleransi terhadap berbagai macam keadaan di lingkungan dan kemampuan yang terbatas dalam bertahan hidup diluar tubuh inang. Mikroba-mikroba yang pathogen secara fisik dapat dikendalikan dengan cara dibasmi dan dihambat pertumbuhannya. Ada beberapa cara untuk mengendalikan mikroba secara fisik antara lain:

1. Hot temparature

a. Tyndalisasi

Pemanasan yang dilakukan untuk makanan dan minuman kaleng. Proses ini dapat membunuh sel vegetatif dan spora mikroba tanpa merusak zat-zat yang terkandung di dalam makanan dan minuman yang diproses. Suhu pemanasan 
pada proses ini sebesar $65^{\circ} \mathrm{C}$ selama 30 menit dalam waktu tiga hari berturut-turut.

b. Pasteurisasi

Proses mematikan mikroba patogen dengan suhu terkendali berdasarkan waktu kematian termal bagi tipe patogen yang paling resisten untuk dibasmi. Pada proses pasteurisasi ini hanya bakteri patogen yang terbunuh serta bakteri penyebab kebusukan. Proses pasteurisasi umunya dilakukan pada susu, rum, anggur dan makanan asam lainnya. Suhu pemanasan adalah $65^{\circ} \mathrm{C}$ selama 30 menit.

c. Boiling

Proses pemanasan dengan cara merebus bahan yang akan disterilkan pada suhu $100^{\circ} \mathrm{C}$ selama $10-15$ menit. Boiling dapat membunuh sel vegetatif bakteri yang patogen maupun non patogen. Namun spora dan beberapa virus masih dapat hidup. Biasanya dilakukan pada alat-alat kedokteran gigi, alat suntik, pipet, dll.

\section{d. Red heating}

Proses pemanasan langsung di atas api bunsen burner (pembakar spiritus) sampai berpijar merah. Umumnya digunakan untuk mensterilkan alat yang sederhana seperti jarum ose.

e. Flaming

Proses pembakaran langsung alat-alat laboratorium diatas pembakar bunsen dengan alkohol atau spiritus tanpa terjadinya pemijaran.

2. Pembekuan

Beberapa bakteri dapat dibunuh dengan temperatur paparan dingin, pembekuan merupakan metode yang tidak layak untuk sterilisasi. Pembekuan dan pencairan secara berulang, lebih merusak bakteri daripada memperpanjang 
penyimpannya pada suhu pembekuan. Pembekuan bakteri akan membentuk kristal es di luar sel yang menyebabkan arus balik air dari bagian dalam sel, mengakibatkan suatu peningkatan elektrolit intraseluler dan denaturasi protein. Membran sel dirusak, dan terjadi suatu kebocoran senyawa organik intraseluler. Bakteri dan virus dapat dapat bertahan hidup pada temperatur $-20^{\circ} \mathrm{C}$ (temperatur alat pembeku mekanis), $-70^{\circ} \mathrm{C}$ (temperatur es kering, yaitu $\mathrm{CO}_{2}$ beku), dan temperatur $-195^{\circ} \mathrm{C}$ (temperatur nitrogen cair).

3. Pendinginan

Temperatur rendah dapat menekan laju metabolisme sehingga pertumbuhan akan berhenti. Dengan pendinginan dapat mengawetkan biakan mikroba karena mikroba dapat bertahan hidup pada keadaan yang sangat dingin. Biakan beberapa bakteri dapat tetap hidup selama berbulan-bulan pada suhu lemari es sekitar $4-7^{\circ} \mathrm{C}$. Kelemahan cara ini yaitu tidak dapat digunakan untuk disinfeksi atau sterilisasi. Karena Mikroba yang dipelihara pada temperatur beku atau di bawah temperatur beku, dianggap dorman karena tidak memperlihatkan adanya aktivitas metabolik yang dapat dideteksi.

\section{Radiasi}

Bakteri dalam bentuk vegetatif dapat terbunuh dengan disinari menggunakan penyinaran ultra violet (UV) dan sinar ionisasi.

a. Sinar ultra violet (UV)

Bakteri yang berada di udara atau yang berada di lapisan permukaan suatu benda yang terpapar sinar UV akan mati.

b. Sinar Ionisasi

Sinar ionisasi adalah sinar X, sinar alfa, sinar beta dan sinar gamma. Sterilisasi dengan sinar ionisasi memerlukan biaya yang besar dan biasanya hanya digunakan pada industri farmasi maupun industri kedokteran. 
> Sinar X : Daya penetrasi baik namun perlu energi besar.

$>$ Sinar alfa : Memiliki sifat bakterisidal tetapi tidak memiliki daya penetrasi.

$>$ Sinar beta : Daya penetrasinya sedikit lebih besar daripada sinar X.

> Sinar gamma : Kekuatan radiasinya besar dan efektif untuk sterilisasi bahan makanan.

4. Filtrasi/penyaringan

Metode yang digunakan dalam laboratorium untuk sterilisasi bahan-bahan yang tidak tahan panas. Prinsip teknik filtrasi yaitu menggunakan penyaringan, hanya bakteri yang tersaring. Jenis filter bakteri yang biasa digunakan adalah Berkefeld (dari fosil diatomae), Chamberland (dari porselen), Seitz (dari asbes) dan seluosa. Macam filtrasi ada dua yaitu:

1) Filter udara berefisiensi tinggi untuk menyaring udara berisikan partikel (High Efficiency Particulate Air Filter atau HEPA) memungkinkan dialirkannya udara bersih ke dalam ruang tertutup dengan sistem aliran udara laminar (Laminar Air Flow).

2) Filter bakteriologis biasanya digunakan untuk mensterilkan bahan-bahan yg tidak tahan terhadap pemanasan, mis. larutan gula, serum, antibiotika, antitoksin, dll.

5. Pengeringan

Metode pengeringan sel mikroba ini dapat mengurangi, mengehentikan aktivitas metabolik sehingga dapat menyebabkan kematian sejumlah sel. Ada beberapa faktor yang mempengaruhi waktu hidup mikroba setelah pengeringa antara lain:

a. Macam mikroorganisme

b. Bahan yang digunakan untuk mengeringkan mikroorganisme

c. Kesempurnaan dalam proses pengeringan 
d. Cahaya, suhu, kelembaban yang dikenakan dalam proses pengeringan.

\section{4 Reproduksi Bakteri}

Semua makhluk hidup mulai yang berukuran mikro sampai ukuran makro melakukan perkembang biakan (reproduksi). Tujuan dari reproduksi adalah untuk memperbanyak jumlahnya dengan menghasilkan generasi selanjutnya. Reproduksi pada mikroorganisme dilakukan melalui dua cara yaitu secara aseksual dan seksual.
A. Aseksual
Reproduksi secara aseksual pada bakteri dibagi menjadi tiga yaitu pertumbuhan tunas (budding), fragmentasi, pembelahan biner (binary fission). Umumnya bakteri akan melakukan perkembangbiakan secara biner tetapi bila kondisi lingkungan tidak menguntungkan maka bakteri akan melakukan perkembangbiakan secara pertumbuhan tunas (budding) dan fragmentasi.
a) Pembelahan biner
pembelahan sel tunggal membentuk dua sel anak yang secara genetik identik dengan sel induknya. Pembelahan biner terdiri atas tiga fase yaitu:
1). Sitoplasma terbelah oleh sekat yang tumbuh tegak lurus
2) Sekat akan tumbuh diikuti oleh terbentuknya dinding yang melintang
3) Terpisahnya kedua sel anak yang identik. 


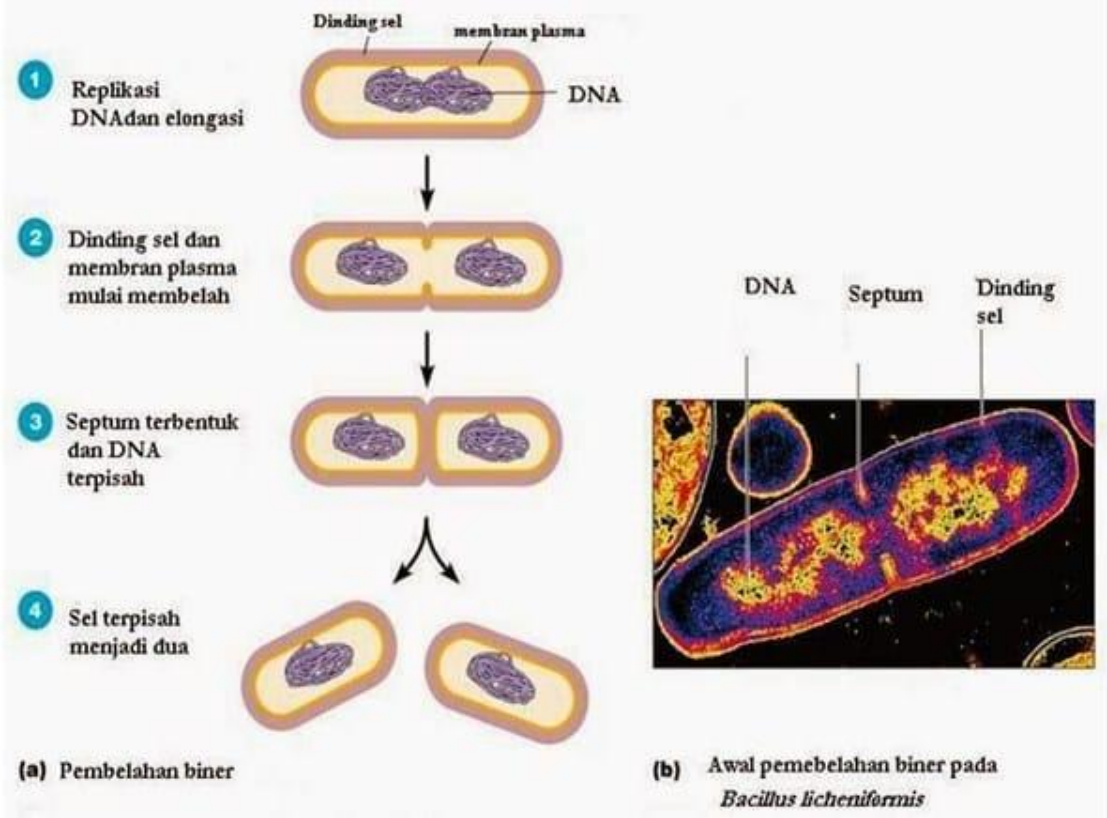

Gambar 3.2 Pembelahan Biner

b) Pertumbuhan tunas (budding)

yaitu proses pembentukan tunas yang dimulai dari berkembang dan tumbuhnya tonjolan kecil pada salah satu ujung sel. Tunas ini yang akan mereplikasi genom, tunas akan tumbuh besar dan menjadi sel anakan. Namun ketika ukuran tunas hampir sama dengan ukuran tunas induknya, maka tunas akan memisahkan diri dari sel induk untuk menjadi bakteri baru.

c) Fragmentasi

Proses perkembangbiakan dengan munculnya bakteri dari bagian tubuh (fragmen) induknya. Induk bakteri akan memutus selnya lalu bagian sel yang terputus akan menajdi bakteri baru dan berkembang hingga dewasa.

B. Seksual 
Perkembangbiakan bakteri secara seksual berbeda dengan organisme eukariota yang melalui peleburan antara gamet jantan dengan gamet betina. Pada bakteri perkembangbiakan seksual melalui pertukaran materi genetik yang disebut dengan rekombinasi genetik. Sel yang memberi bahan genetik disebut sel donor sedangkan sel yang menerima bahan genetik disebut sel resipien. Perkembangbiakan secara seksual dapat dilakukan dengan beberapa cara antara lain:

\section{a. Transformasi}

Proses pemindahan materi genetik berupa DNA dari satu sel bakteri ke sel bakteri lainnya. Pada proses ini DNA sel bakteri donor akan mengganti sebagian dari sel bakteri penerima tetapi tidak terjadi melalui kontak secara langsung. Pemindahan materi genetik melalui perantara plasmid. Bila plasmid satu bakteri masuk ke dalam bakteri lainnya maka akan terjadi rekombinasi.
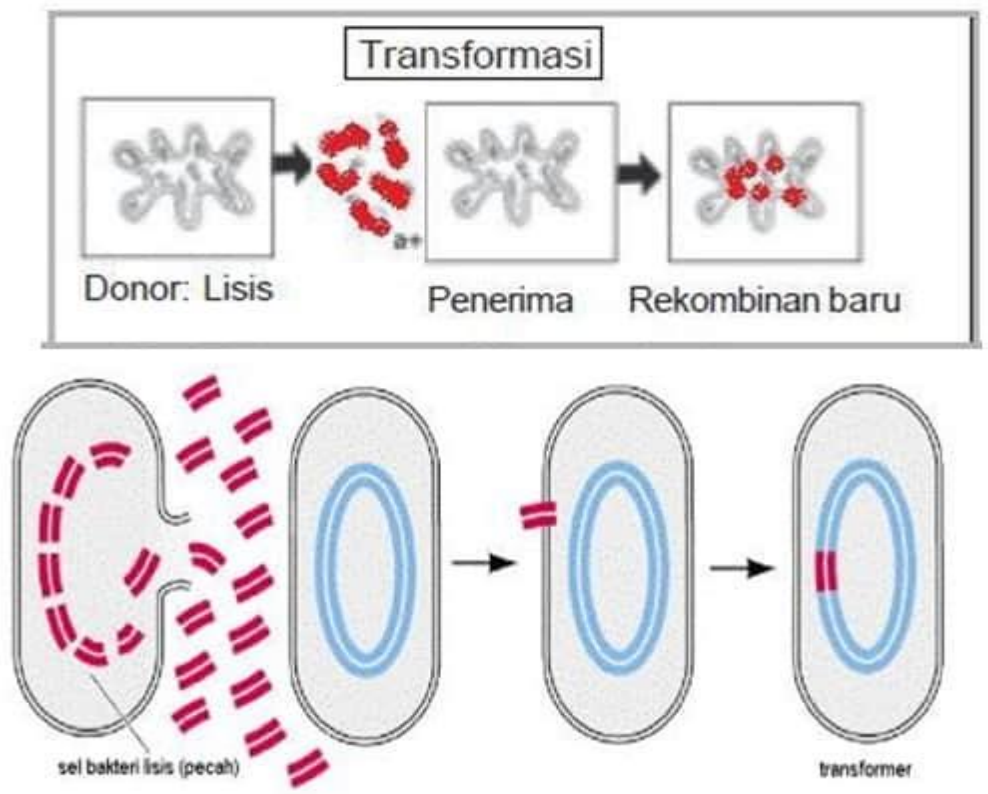

Gambar 3.3 Proses Transformasi 


\section{b. Transduksi}

Proses pemindahan materi genetik dari sel bakteri satu ke bakteri lain melalui perantara virus yang memakan bakteri (bakteriofag). Virus yang paling sesuai digunakan untuk proses transduksi ini adalah virus fag temperat. Hal itu karena virus ini mampu bereplikasi secara litik dan lisogenik. Adapun tahapan dalam transduksi adalah sebagai berikut.

- Bakteri diinfeksi oleh virus fag, sehingga virus mengandung DNA bakteri tersebut.

- Virus fag tersebut kemudian akan menginfeksi bakteribakteri lainnya. Akibatnya, terbentuk bakteri baru dengan rekombinasi gen sesuai dengan rekombinasi gen pada virus penginfeksinya.

- Terbentuklah bakteri-bakteri rekombinan. 


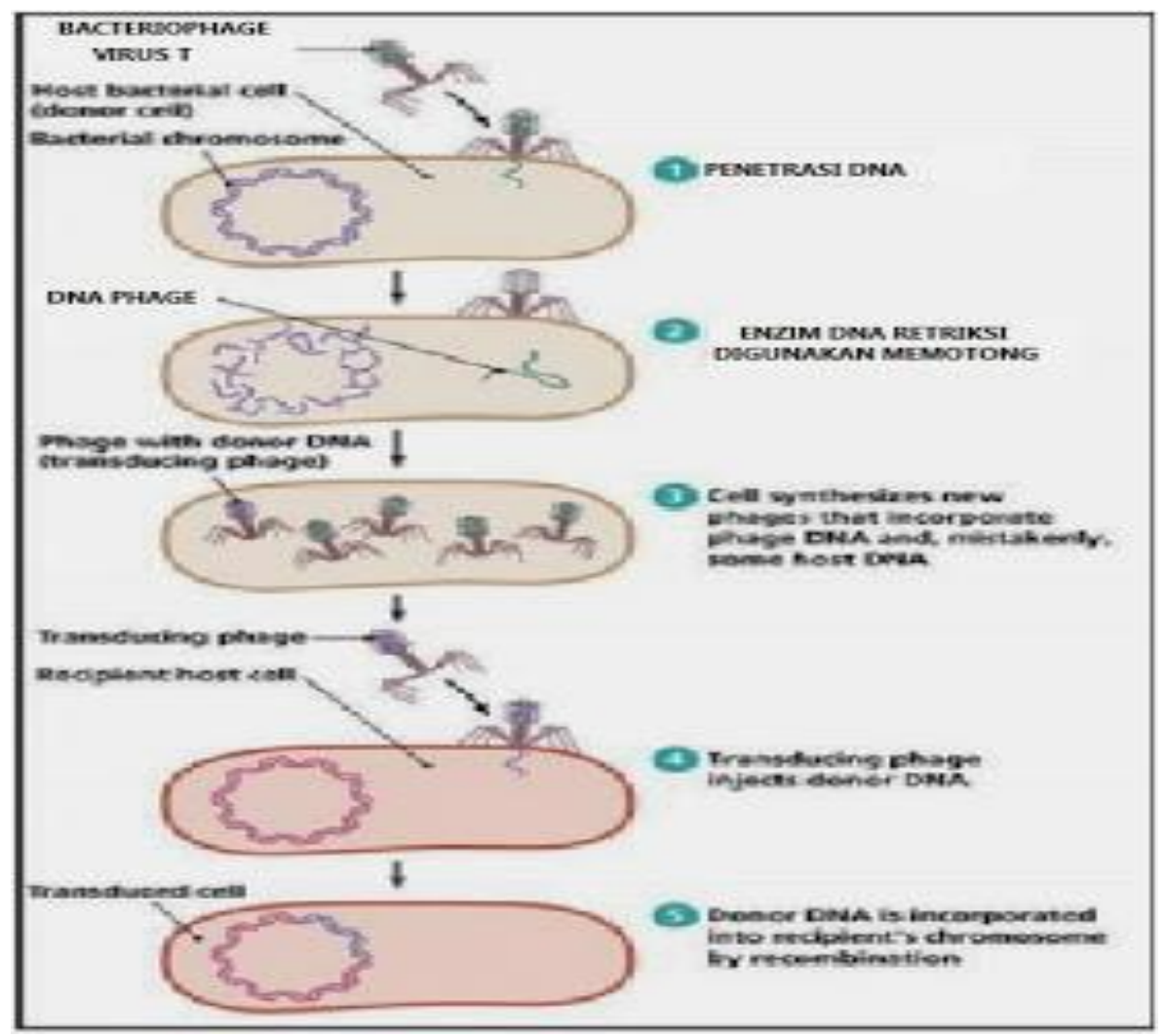

Gambar 3.4 Proses Transduksi

\section{c. Konjugasi}

Proses pemindahan sebagian materi genetik dari satu bakteri ke bakteri yang lain secara langsung melalui saluran konjugasi sehingga kedua sel saling berhubungan dan terjadi kontak langsung. Dengan pentransferan DNA dari sel bakteri donor ke sel bakteri penerima melalui ujung pilus. Ujung pilus akan menempel pada sel penerima dan DNA akan dipindahkan melalui ujung pilus. 


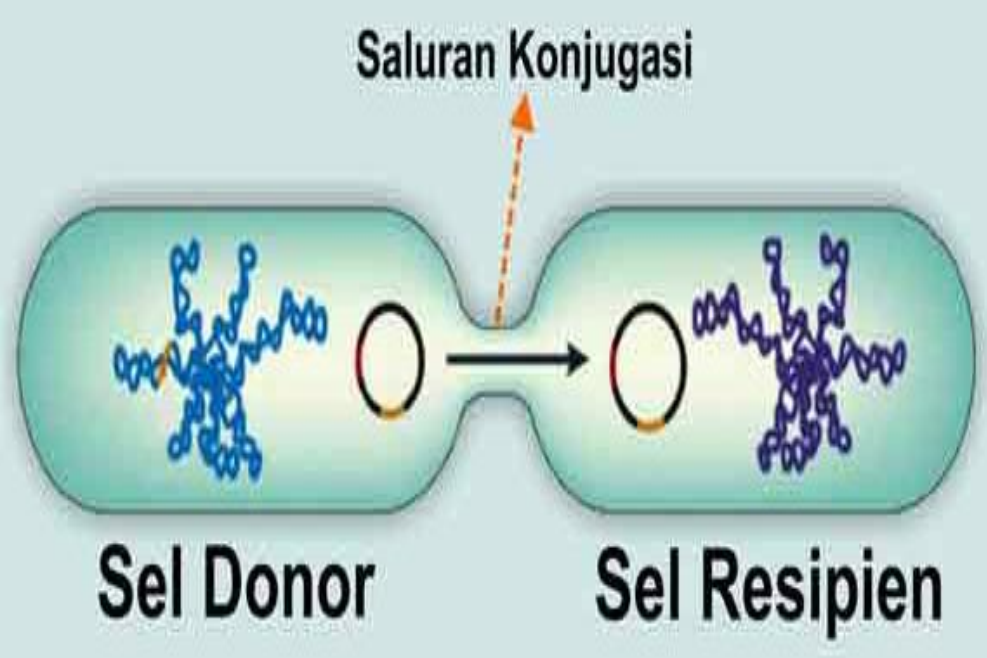

Gambar 3.5 Proses Konjugasi

\section{KESIMPULAN}

Pertumbuhan merupakan proses bertambahnya ukuran atau subtansi atau masa zat suatu organisme. Pertumbuhan mikroorganisme dipengaruhi oleh faktor biotik maupun faktor abiotik. Proses tahapan pertumbuhan mikroorganisme dari awal pertumbuhan hingga kematian di gambarkan dengan kurva pertumbuhan. Tahapan pertumbuhan bakteri terdiri atas empat fase antara lain fase lag, fase eksponensia, fase stasioner, fase kematian. Reproduksi pada bakteri tejadi secara aseksul dan seksual. 


\section{LATIHAN SOAL}

1. Jelaskan faktor-faktor yang mempengaruhi pertumbuhan mikroba!

2. Jelaskan fase-fase pertumbuhan mikroba!

3. Jelaskan bagaimana cara pengendalian mikroba!

4. Jelaskan reproduksi secara aseksual dan seksual pada bakteri! 


\section{BAB IV BAKTERI PATOGEN PADA MANUSIA}

\section{TUJUAN INSTRUKSIONAL:}

1. Mahasiswa mengetahui infeksi bakteri

2. Mahasiswa mengetahui kelompok bakteri dalam menyebabkan penyakit pada manusia.

\subsection{Infeksi Bakteri}

Bakteri dikenal sebagai agen penyebab penyakit, bakteri juga mempunyai manfaat yang besar bagi kehidupan manusia seperti pemanfaatan bakteri dalam pembuatan yogurt dan antibiotik. Bakteri merupakan sel prokariotik dengan genom berbentuk sirkuler dan mempunyai plasmid. Di dalam tubuh manusia bakteri memberikan manfaat yang banyak antara lain sebagai pertahanan melawan infeksi, berperan dalam sistem imun, sumber nutrient dan menstimulasi pergantian epitel.

Bakteri yang hidup pada tubuh manusia disebut mikroba flora normal. Mikroba flora normal dibagi menjadi dua kelompok yaitu:

(1) Flora penghuni tetap yang ditemukan pada daerahdaerah tertentu, menghilang bila terjadi gangguan dan kembali seperti semula.

(2) Flora transit, mikroba patogen \& non-patogen pada selaput lendir dan mukosa.

Walaupun mikroba flora normal penghuni alami tubuh tetapi ada kalanya bakteri dapat bersifat patogen pada inangnya. Salah satu faktor patogen mikroba flora normal yaitu infeksi opurtunistik. Bakteri dapat menginfeksi manusia melalui beberapa tahapan yaitu:

a. Melekatnya bakteri pada sel epitel, pelekatan ini melibatkan molekul interaksi.

b. Terjadi multipikasi bakteri yakni bakteri membentuk mikro koloni dan menghasilkan enzim yang mampu menembus epitel. Setelah multiplikasi bakteri melakukan penyebaran 
dalam sel tubuh manusia dengan menghasilkan enzim hialuronidase yang merusak asam hialuronat dan memecahkan kolagen. Selain itu bakteri juga menghasilkan metabolitmetabolit lainnya seperti enzim dan toksin. Faktor yang menyebabkan suatu bakteri menjadi patogen disebut faktor virulensi. Faktor virulensi ini terdiri atas adhesion, toksin, enzim dan faktor antifagositik. Mikroorganisme patogen memiliki sifat virulen (ganas) yang dapat menyebabkan penyakit pada individu sehat meskipun dalam jumlah inokulum kecil. Sedangkan mikroorganisme yang menyebabkan sakit pada individu dengan penurunan daya tahan tubuh disebut mikroorganisme opportunistik.

Penyakit yang dapat ditularkan atau infeksi adalah jika penyakit disebarkan dari inang satu ke inang lainnya. Penyakit infeksi yang dapat ditularkan contohnya tuberculosis karena penyakit tersebut dapat disebarkan melalui percikan ludah yang dihasilkan ketika batuk akan tetapi keracunan makanan oleh bakteri Staphylococcus bukan penyakit menular karena racun (toksin) yang dihasilkan oleh bakteri tersebut berada pada makanan yang terkontaminasi. Penyakit ini diderita oleh individu yang memakan makanan tersebut. Bila suatu penyakit sangat mudah disebarkan disebut penyakit yang sangat menular contohnya cacar air.

Tingkat insidensi dan prevalensi suatu penyakit infeksi dimasyarakat dapat bersifat endemik, epidemik, pandemik.

- Penyakit infeksi endemik

Yaitu suatu penyakit yang menetap dengan kadar rendah di suatu populasi yang spesifik contohnya penyakit endemik malaria di Papua.

- Penyakit infeksi epidemik

Yaitu bila suatu penyakit yang sering terjadi bila dibandingkan dengan kondisi biasa contohnya epidemik influenza pada musim dingin.

- Penyakit infeksi pandemik 
Yakni suatu penyakit yang menyebar secara luas hampir diseluruh dunia contohnya infeksi HIV, Covid 19.

Infeksi lama kelamaan akan berkembang. Tahapan perkembangan infeksi antara lain:

1) Periode inkubasi

Yaitu waktu saat mikroorganisme masuk atau toksinnya hingga munculnya symptom atau gejala. Hal ini dapat berlangsung dari beberapa jam sampai beberapa minggu

2) Periode prodromal

Yaitu individu yang mengalami gejala-gejala nonspesifik seperti demam, malaise dan hilangnya nafsu makan

3) Periode sakit spesifik akut

Yaitu gejala dan tanda penyakit yang secara khas terlihat nyata 4) Periode penyembuhan

Yaitu sakit sedikit demi sedikit akan hilang dan pasien kembali sehat pada fase akhir tahap ini.

Beberapa infeksi dapat terjadi reaktivasi pertumbuhan mikroorganisme dan berulangnya gejala pada tahap laten contohnya setelah infeksi herpes primer, virus dapat menetap di ganglion saraf trigerminal, dan menyebabkan herpes labialis yang berulang sewaktu waktu. Beberapa mikroorganisme menyebabkan infeksi yang subklinis atau tidak nyata yakni gejala yang terlihat tidak nyata, dan individu yang terkena tidak memperlihatkan gejala meskipun pasien terinfeksi oleh mikroorganime tersebut. Kasus lainnya ada individu yang terinfeksi, dan tubuhnya tidak mampu menghilangkan kehadiran mikroorganisme patogen tersebut setelah periode penyembuhan, sehingga tubuh menjadi karier kronik mikroorganisme contohnya Salmonella typhi, Hepatitis B virus. Mikroorganisme akan tetap berada didalam tubuh meskipun pasien tetap sehat.

Ada beberapa cara bakteri dapat menyebabkan penyakit atau seseorang penderita sakit. Cara itu antara lain melalui transmisi (penularan atau pemindahan bakteri), perlekatan pada 
permukaan sel inang, menyerang (invasive) dan toksigenitas (melepaskan toksin atau racun).

a. Transmisi atau Penularan

Penyakit infeksi yang disebabkan oleh bakteri yang pindah dari sumber luar disebut eksogen. Penyakit lain yang disebabkan oleh flora normal dari tubuh inangnya sendiri yang bertindak selaku bakteri oportunistik disebut endogen. Penularan dapat terjadi melalui:

- Inhalasi yaitu melalui jalur udara

- Ingesti yaitu melalui jalur penelanan makanan dan minuman yang terkontaminasi

- Inokulasi yaitu melalui kontak seksual, jarum suntik terkontaminasi, kontak kulit, transfusi darah atau gigitan serangga.

Mikroorganisme dapat masuk ke tubuh melalui kulit, saluran pernafasan, saluran pencernaan dan saluran genitourinaria. Contoh bakteri pathogen:

- Kulit yaitu Clostridium tetani (penyakit tetanus),

- Saluran pernafasan yaitu Streptococcus pneumoniae (penyakit pneumoniae), Haemophilus influenza (penyakit meningitis), Mycobacterium tuberculosis (penyakit tuberculosis)

- Saluran pencernaan yaitu Shigella dysentriae (penyakit disentri), Vibrio cholera (penyakit kolera)

- Saluran genital yaitu Neisseria gonorrhoeae (penyakit gonoroe), Treponema pallidum (penyakit sifilis)

b. Perlekatan pada permukaan sel atau jaringan inang

Merupakan tahap awal infeksi. Beberapa bakteri dan fungi mempunyai struktur khusus atau menghasilkan bahan khusus yang sehingga dapat melekat pada permukaan sel inang 
termasuk pada protesa gigi, katup jantung buatan dan sebagainya sehingga dapat meningkatkan kemampuan bakteri untuk berkolonisasi dan menjadi penyakit. Mekanisme perlekatan adalah hal yang esensial bagi mikroorganisme untuk melekat pada membran mukosa misalnya rambut yang menyerupai pili pada Neisseria gonorrhoeae, Streptococcus mutans membantunya menempel pada permukaan email gigi.

c. Daya serang Bakteri (Invasif)

Daya invasif bakteri berfungsi dalam patogenesis. Daya serang ini berhubungan dengan enzim yang disekresikan oleh bakteri. Enzim-enzim tersebut adalah :

- Kolagenase atau hialuronidase

Merusak substansi interseluler jaringan inang, sehingga bakteri mudah masuk dan menyebar di jaringan, khususnya pada infeksi di kulit yang disebabkan oleh Streptococcus pyogenes.

\section{- Koagulase}

Enzim yang dihasilkan oleh Staphylococcus aureus berfungsi untuk mempercepat pembentukan bekuan fibrin (dari fibrinogen). Kondisi ini melindungi bakteri dari proses fagositosis yakni proses sel darah putih manusia memakan bakteri tersebut dengan cara membentengi daerah yang terinfeksi dan melingkupi bakteri dengan lapisan fibrin.

- Immunoglobulin A ( $\operatorname{Ig}$ A) protease

enzim yang dihasilkan bakteri yang dapat merusak IgA inang pada permukaan mukosa, sehingga bakteri-bakteri seperti N. gonorrhoeae, Haemophilus influenza dan Streptococcus pneumonia melekat pada membrane mukosa.

- Leukosidin

Racun yang dihasilkan bakteri yang dapat menghancurkan sel-sel darah putih manusia jenis netrofil dan makrofaga. Toksin ini dimiliki oleh bakteri-bakteri penyebab penyakit periodontal seperti Actinobacillus actinomycetemcommitans.

d. Toksigenitas 
Toksigenitas ialah faktor penentu patogenesis bakteri. Toksin yang dihasilkan bakteri dapat digolongkan menjadi dua kelompok utama yaitu : eksotoksin dan endotoksin.

- Endotoksin adalah komponen lipopolisakarida (LPS) dinding sel bakteri Gram negatif (kokus maupun basil) yang tersimpan dan tidak secara aktif dikeluarkan oleh bakteri. Bakteri Gram positif tidak menghasilkan toksin ini. Endotoksin dapat menyebabkan demam, syok dan gejala umum lainnya. Endotoksin akan dilepaskan dari tubuh bakteri jika bakteri mengalami lisis (hancur, mati).

- Eksotoksin adalah toksin yang dihasilkan dan dikeluarkan dari badan bakteri Gram positif dan Gram negatif. Eksotoksin dapat menyebabkan penyakit dibagian tubuh tertentu setelah menyebar atau terbawa melalui jalur sistemik misalnya bakteri penyebab tetanusyang masuk melalui luka di kaki menghasilkan eksotoksin yang dapat menyebabkan rahang terkunci atau kejang otot masseter (pengunyahan) di daerah wajah. Eksotoksin labih toksik dibandingkan dengan endotoksin. Contohnya toksin tetanus dapat menyebabkan kematian pada kadar $<1 \mu \mathrm{g}$. Polipeptida eksotoksin merupakan antigen kuat yang dapat merangsang antibody tubuh membentuk antitoksin berguna untuk mencegah atau mengobati penyakit contohnya tetanus. Toksisitas eksotoksin dapat dinetralisir oleh formaldehyde, asam, pemanasan dan toksoid yang dapat dimanfaatkan untuk pembuatan vaksin. 
Secara umum eksotoksin bakteri dapat dibagi menjadi :

- Neurotoksin

yaitu toksin yang berpengaruh terhadap saraf. Contohnya : toksin tetanus (dihasilkan oleh Clostridium tetani), toksin difteria (dihasilkan oleh Corynebacterium diptheriae) dan toksin botulinum (yang dihasilkan oleh Clostridium botulinum).

- Enterotoksin

yaitu toksin yang berefek racun terhadap mukosa usus dan dapat menyebabkan gangguan gastrointestinal. Contohnya toksin yang dihasilkan oleh Eschericia coli, Vibrio cholera dan Bacillus cereus.

- Eksotoksin lainnya,

Contohnya toksin yang dihasilkan oleh bakteri Clostridium perfringens dapat menyebabkan gas gangrene pada luka.

Tabel 4.1 Perbedaan Endotoksin dan Eksotoksin

\begin{tabular}{|l|l|l|}
\hline Sumber & Endotoksin & Eksotoksin \\
\hline Asal & $\begin{array}{l}\text { Dikeluarkan dari } \\
\text { dalam sel }\end{array}$ & $\begin{array}{l}\text { Komponen } \\
\text { dinding sel }\end{array}$ \\
\hline Sumber & $\begin{array}{l}\text { Spesies Gram } \\
\text { positif dan negatif }\end{array}$ & $\begin{array}{l}\text { Spesies Gram } \\
\text { negatif }\end{array}$ \\
\hline Tosisitas & $\begin{array}{l}\text { Tinggi dengan } \\
\text { dosis fatal pada 1 } \\
\mu g\end{array}$ & $\begin{array}{l}\text { Rendah dosis fatal } \\
\text { bila dihasilkan } \\
\text { oleh rusan } \\
\text { mikroorganisme }\end{array}$ \\
\hline Efek klinis & bervariasi & Demam, syok \\
\hline antigenitas & $\begin{array}{l}\text { Menghasilkan } \\
\text { antibody dengan } \\
\text { titer tinggi disebut } \\
\text { antitoksin }\end{array}$ & Antigen lemah \\
\hline vaksin & Toksoid dapat & Tidak \\
\hline
\end{tabular}




\begin{tabular}{|l|l|l|}
\hline & $\begin{array}{l}\text { digunakan sebagai } \\
\text { vaksin }\end{array}$ & $\begin{array}{l}\text { pembentukan } \\
\text { toksoid dan tidak } \\
\text { dapat dibuat } \\
\text { vaksin }\end{array}$ \\
\hline $\begin{array}{l}\text { Stabilitas terhadap } \\
\text { panas }\end{array}$ & $\begin{array}{l}\text { Bersifat } \\
\text { thermolabil (cepat } \\
\text { rusak pada } \\
\text { pemanasan } 60^{\circ} \mathrm{C}\end{array}$ & $\begin{array}{l}\text { Thermostabil pada } \\
\text { suhu } 100^{\circ} \mathrm{C} \text { selama } \\
1 \text { jam }\end{array}$ \\
\hline
\end{tabular}

\subsection{KELOMPOK BAKTERI PATOGEN \\ 1. Kelompok Bakteri Gram-Negatif}

a. Salmonella sp

Bakteri Salmonella sp merupakan salah satu bakteri penyebab utama food borne disease di Amerika Serikat. Karena bakteri ini sering ditemukan dalam bahan makanan atau minuman dan merupakan salah satu bakteri patogen yang sering menginfeksi manusia melalui makanan dan minuman yang terkontaminasi.

Masuknya bakteri Salmonella sp ke dalam tubuh manusia, dapat berpengaruh terhadap kesehatan, diantaranya dapat menyebabkan penyakit gastroenteritis, demam tifoid dan bakteremia dengan atau tanpa penyakit.

Gastroenteritis yang disebabkan oleh salmonella merupakan infeksi pada usus dan terjadi lebih dari 8 sampai 48 jam setelah bakteri patogen itu masuk ke dalam host.

Ciri-cirinya adalah diare, demam, sakit kepala, muntah, sakit pada abdomen (abdominal pain) yang terjadi selama 2 sampai 5 hari.

Gejalanya antara lain kehilangan cairan dan kehilangan keseimbangan elektrolit merupakan bahaya terutama terhadap anak-anak dan orang tua.

\section{b. Escherichia coli}


Penyakit diare merupakan penyebab kesakitan dan kematian di negara Berkembang. Escherichia coli merupakan bakteri komensal, patogen intestinal dan pathogen ekstraintestinal yang dapat menyebabkan infeksi traktus urinarius, meningitis, dan septicemia.

Infeksi ditandai dengan manifestasi klinis yang luas mulai dari tanpa menunjukkan gejala klinis atau asimtomatis sampai terlihat adanya diare berdarah atau tanpa berdarah.

\section{c. Klebsiella ozaena}

Menyebabkan penyakit ozaena memberikan gejala pembentukan granul (bintik-bintik), gangguan hidung, benjolan-benjolan di rongga pernapasan (terutama hidung), sakit kepala, serta ingus hijau dan berbau. Penyebab penyakit ozaena masih belum diketahui, namun diduga diakibatkan oleh Klebsiella ozaenae dan Bacillus foetidus.

\section{d. Pseudomonas aeruginosa}

Pseudomonas aeruginosa sering menyebab infeksi oportunistik dan infeksi nosokomial pada manusia. Pseudomonas aeruginosa dapat menyebabkan terjadinya infeksi primer pada kulit. Infeksi yang paling sering terjadi adalah ulkus diabetikum. Kolonisasi pada ulkus diabetikum diikuti dengan kerusakan pembuluh darah lokal, nekrosis jaringan, dan akhirnya terjadi bacteremia. Gejala dapat berupa iritasi, kemerahan, keluar cairan serta kaki tampak bengkak.

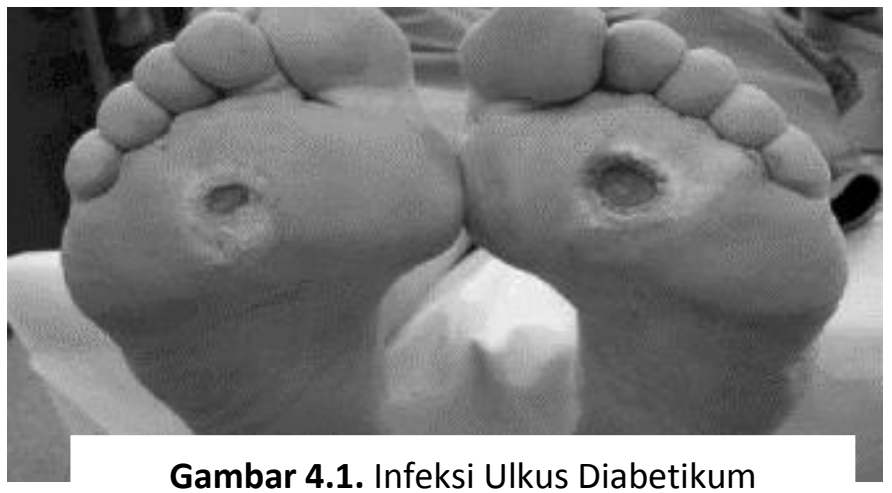




\section{e. Shigella dysenteriae}

Disentri merupakan penyakit radang usus yang menimbulkan gejala meluas, tinja lendir bercampur darah. Penyakit disentri disebabkan oleh bakteri (Disentri basiler) atau biasa disebut dengan shigellosis disebabkan oleh bakteri genus Shigella (penyebab disentri yang terpenting dan tersering). Ditandai gejala diare, adanya lendir dandarah dalam tinja, serta nyeri perut dan tenesmus.

\section{f. Klebsiella pneumonia}

Pneumonia adalah proses infeksi akut yang mengenai jaringan paru-paru (alveoli). Pneumonia yang disebabkan oleh Klebsiella pneumonia dapat berupa pneumonia komuniti (community acquired pneumonia). Klebsiella pneumoniae merupakan jenis bakteri golongan Klebsiella yang banyak menginfeksi manusia. Merupakan organisme oportunis yang ditemukan pada lapisan mukosa mamalia, terutama paru-paru. Memiliki penyebaran yang sangat cepat, terutama di antara orang-orang yang sedang terinfeksi bakteri.

Gejalanya dapat berupa pendarahan dan penebalan lapisan mukosa organ. Bakteri Klebsiella pneumonia selain penyebab penyakit pneumonia juga merupakan salah satu bakteri yang menyebabkan penyakit bronchitis.

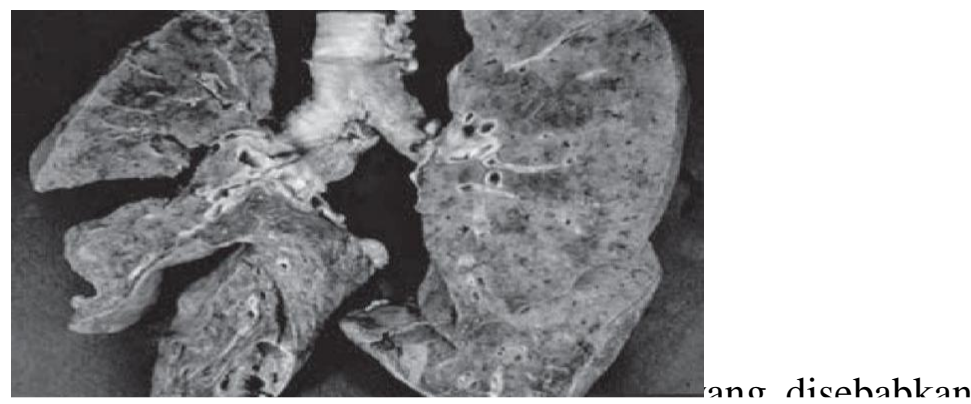

Gambar 4.2 Kerusakan jaringan paru akibat pneumonia oleh K.pneumonia makanan, minuman yang terkontamınası oıena bakterı vıprı cholerae. Atau kontak dengan carrier kolera. Dalam usus halus bakteri Vibrio cholerae ini akan beraksi dengan cara 
mengeluarkan toksinnya pada saluran usus, sehingga terjadilah Diare disertai Muntah yang akut dan hebat.

Gejala bakteri Vibrio cholerae apabila masuk ke dalam tubuh seseorang melalui makanan dan minuman yang telah terkontaminasi oleh bakteri akan mengeluarkan Enterotoksin di dalam tubuh seseorang pada bagian saluran usus, sehingga menimbulkan diare disertai muntah yang akut dan sangat hebat, dan berakibat seseorang dalam waktu hanya beberapa hari akan kehilangan banyak cairan dalam tubuhnya sehngga mengalami dehidrasi.

\section{h. Neisser meningtidis}

Penyakit meningitis adalah penyakit yang menyerang saluran pernafasan dan mengakibatkan meningitis. Meningitis mengakibatkan peradangan selaput otak dan saraf punggung, dan atau septisemia (keracunan darah). Penyakit ini disebabkan oleh bakteri Neisser meningtidis.

Meningitis umumnya ditularkan saat batuk, bersin, ciuman, dan berbagi makanan dengan sendok yang sama, pemakaian sikat gigi yang sama dan merokok bergantian dalam satu batang. Meningitis dapat disebabkan oleh mikroorganisme, kanker, luka fisik dan juga obat-obatan. Jika tertular penyakit ini maka akan beresiko menjadi carrier, dan infeksius. Masa inkubasi penyakit ini rata-rata 3-4 hari sampai gejalanya terlihat. Penyakit ini umumnya terjadi 1-14 hari setelah paparan dan muncul sebagai meningitis pada $\geq 50 \%$ kasus.

Gejala dari meningitis tidak spesifik tetapi mungkin termasuk demam, sakit kepala, kekejangan leher, sakit sendi, ruam dengan bintik atau lebam ungu, kurang senang dengan cahaya cerah, dan muntah secara mendadak.

\section{i. Haemophilus influenza}

Haemophilus influenzae merupakan bakteri patogen pada manusia yang dapat menyebabkan influenza, meningitis, pneumonia dan bakteremia. Infeksi influenza merupakan penyebab utama morbiditas dan mortalitas. Penyebar dapat 
melalui udara berupa percik renik dari saluran respiratorik orang yang terinfeksi, yang batuk, bersin, atau melalui kontak langsung dari tangan yang terkontaminasi oleh sekret respiratorik.

Gejala sistemik utama infeksi influenza adalah demam, sakit kepala, nyeri otot, lemas, batuk, dan nyeri menelan. Infeksi influenza berusia <5 tahun merupakan infeksi terbanyak dengan gejala yang lebih ringan.

\section{j. Neisseria gonorrhoeae}

Gonore merupakan penyakit kelamin terbanyak dewasa ini. Tidak ada imunitas bawaan, walaupun bagi orang yang pernah menderita penyakit ini. Juga tidak ada perbedaan mengenai kekebalan antara berbagai suku bangsa, jenis kelamin atau umur. Penyakit Gonore disebabkan oleh bakteri Neisseria gonorrhoeae.

Penularan terjadi melalui kontak seksual dengan penderita gonore. Masa inkubasi penyakit sangat singkat, pada pria umumnya bervariasi antara 2-8 hari, dengan kebanyakan infeksi menjadi simptomatik dalam 2 minggu. Masa inkubasi pada wanita sulit ditentukan karena pada umumnya asimptomatik, dan baru diketahui setelah terjadinya komplikasi.

Gejala klinis untuk infeksi pertama yang paling sering dijumpai pada pria adalah uretritis anterior akuta dan dapat meluas ke proksimal, selanjutnya mengakibatkan komplikasi lokal, asendend dan diseminata. Keluhan subyektif berupa rasa gatal dan panas di bagian distal uretra di sekitar orifisium uretra eksternum kemudian disusul disuria, polakisuria, keluar duh tubuh mukopurulen pada orifisium uretra eksternum yang kadang-kadang disertai darah, dan disertai perasaan nyeri pada waktu ereksi.

Gejala yang terjadi pada wanita dengan gonore sering mengenai serviks sehingga terjadi servisitis dengan gejala keputihan. Pada pemeriksaan, serviks yang terinfeksi tampak rapuh dan mengalami edema dengan keluarnya cairan 
mukopurulen pada ostium. Perempuan yang sedikit atau tidak memperlihatkan gejala menjadi sumber utama penyebaran infeksi dan beresiko mengalami komplikasi.
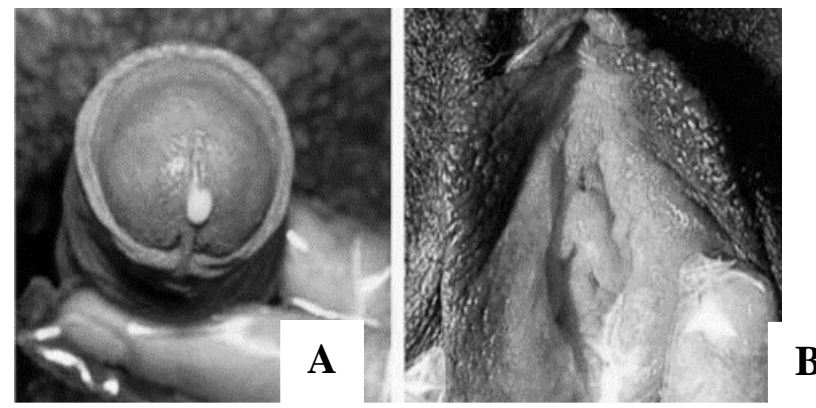

Gambar 4.3 A. Gonore Pada Pria; B. Gonore Pada Wanita

\section{k.Treponema pallidium}

Penyakit frambusia atau patek adalah penyakit infeksi kulit yang menular melalui kontak dengan penderita. Penyakit ini bersifat menahun dan dapat menyebabkan kecacatan. Yaws atau frambusia adalah penyakit infeksi treponema nonvenereal pada manusia yang disebabkan oleh bakteri Treponem pallidium. Penyakit ini dapat mengenai semua usia, namun terutama ditembukan pada usia dibawah 15 tahun.

Gejala dapat berupa konstitusi malese, demam dan anoreksia. Sedangkan gejala klinis lain dapat berupa plak hiperkeratotik pada telapak tangan dan kaki, dapat terjadi fisura dan ulserasi (worm-eaten soles), dan infeksi sekunder yang nyeri sehingga penderita biasanya menunjukkan tanda khas yaitu "crab-like gait" 


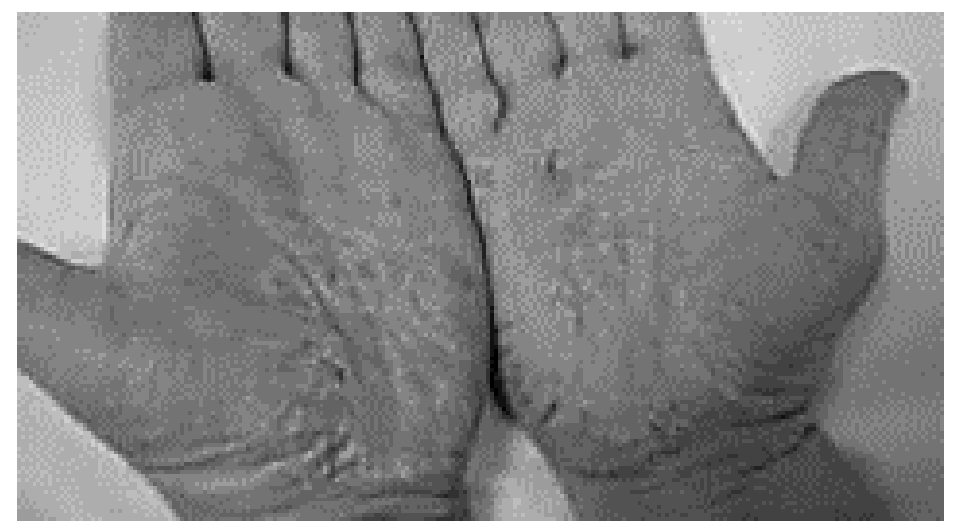

Gambar 4.4 Penyakit Frambusia Pada Telapak Tangan

\section{Proteus vulgaris}

Abses leher dalam adalah terkumpulnya nanah (pus) di ruang potensial diantara fasia leher dalam. Salah satu bakteri penyebab abses leher dalam adalah baktei Proteus vulgaris. Infeksi leher dalam berasal dari penyebaran infeksi di faring dan tonsil ke parafaring.

Gejala dan tanda klinik berupa nyeri dan pembengkakan di ruang leher dalam yang terkena. Secara anatomi ruang potensial leher dalam merupakan daerah yang sangat kompleks.

\section{m. Chlamydia trachomatis}

Chlamydia trachomatis (CT) termasuk salah satu penyebab infeksi genital nonspesifik baik pada pria maupun wanita. Infeksi Chlamydia trachomatis merupakan infeksi menular seksual yang disebabkan oleh bakteri obligat intraseluler genus Chlamydia. Infeksi Chlamydia trachomatis dapat mengenai saluran genital 8 pria dan wanita, konjungtiva, dan paru-paru. Infeksi Chlamydia trachomatis pada saluran genital pria dan wanita dapat bersifat asimtomatik pada sebagian besar orang yang terinfeksi dan dapat menimbulkan komplikasi serius. 
Gejala yang timbul tidak spesifik, pada pria yang terinfeksi $50 \%$ asimtomatik, sedangkan pada 10 wanita $70 \%$ asimtomatik.

a. Infeksi CT pada pria dapat mengenai uretra dan epididimis. Infeksi di rektum dapat terjadi pada pria yang menerima seks secara anal. Masa inkubasi uretritis disebabkan oleh CT bervariasi sekitar 7 hari sampai 5 minggu. Biasanya gejalanya yaitu adanya nyeri pada saat buang air kecil (disuria).

b. Hampir $70 \%$ wanita dengan infeksi Chlamydia tidak mengeluhkan gejala apapun, namun dapat ditemukan kelainan apabila dilakukan pemeriksaan di daerah serviks. Infeksi awal akan terjadi pada serviks atau uretra. Keluhan yang timbul berupa tubuh yang abnormal dan rasa terbakar saat buang air kecil. Adanya perdarahan yang muncul setelah kontak seksual ataupun perdarahan pada pertengahan siklus menstruasi dapat merupakan gejala tunggal infeksi ini.

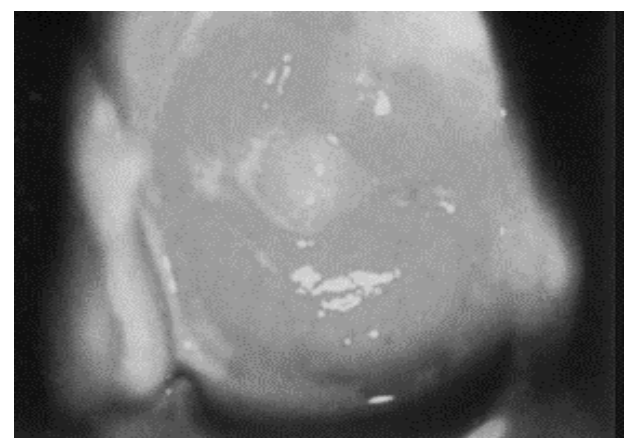

Gambar 4.5 Infeksi Chlamydia trachomatis pada serviks 
Penyakit Pes disebabkan oleh bakteri Yersinia pestis yang endemik pada rodent yang hidup di alam liar yang disebarkan oleh gigitan pinjal. Pinjal tikus adalah vektor utama penyebab penyakit pes. Pes pada tikus serta rodent lain dapat menyebabkan penularan pada manusia. Pinjal sebagai vektor utama penyakit pes berperan menularkan bakteri Yersinia pestis yang terdapat di dalam darah tikus yang terjangkit kepada manusia melalui gigitannya. Pinjal selain menjadi vektor utama pes juga bisa menjadi vektor penyakit serius lain pada manusia yaitu penyakit murine typhus yang dapat ditularkan dari tikus ke manusia. Gigitan pinjal yang telah terinfeksi khususnya Xenopsylla cheopis merupakan sumber paparan yang paling sering terjadi yang menghasilkan penyakit pada manusia di seluruh dunia.

Penyakit Pes memiliki gejala diantaranya yaitu penderita demam tinggi tanpa sebab yang jelas, batuk dan sesak yang diduga sebagai suspek Pes.

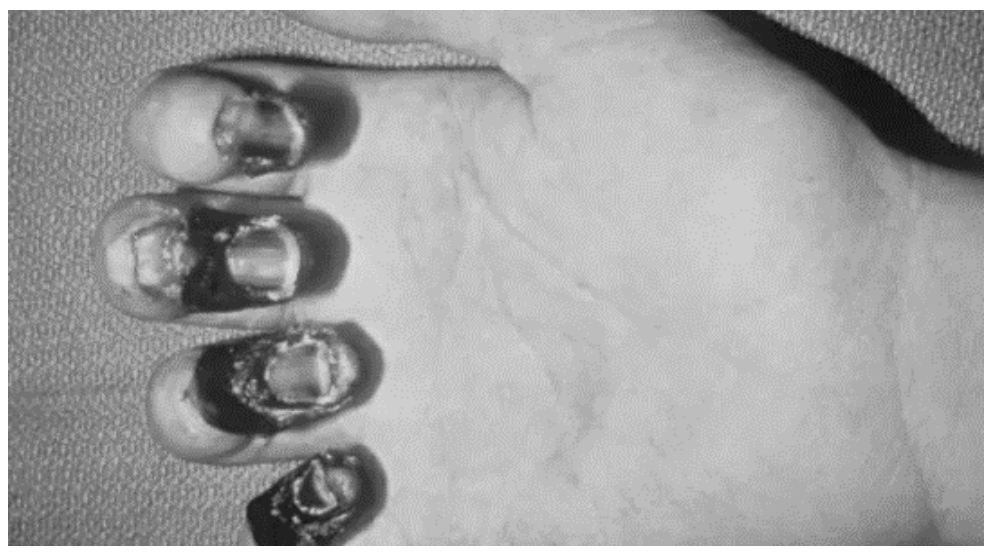

Gambar 4.6 Penyakit Pes atau Plague

\section{o. Bordetella pertussis}

Bordetella pertussis adalah bakteri yang menyerang saluran pernapasan dan sangat mudah menular. Organisme ini 
menghasilkan toksin yang merusak epitel saluran pernapasan dan memberikan efek sistemik berupa sindrom yang terdiri dari batuk spasmodik dan paroksismal disertai mengi karena pasien berupaya keras untuk menarik napas, sehingga pada akhir batuk. Serangan batuk seringkali diikuti oleh muntah dan dapat berlangsung berbulan-bulan.

Bordetella pertussis yang diambil setelah sebulan timbulnya gejala batuk disertai pengeluaran lendir, dan tarikan napas, muntah, badan panas, pusing, sakit tenggorok.

\section{Kelompok Bakteri Gram-positif}

\section{a. Clostridium botulinum}

Clostridium botulinum yaitu bakteri yang memproduksi neurotoksin yang menyerang saraf dan menyebabkan kelumpuhan. Penyakit yang disebabkan oleh bakteri Clostridium botulinum adalah Botulisme yaitu penyakit disebabkan oleh keracunan makanan atau mabuk makanan oleh Clostridium botulinum.

Gejala apat berupa mual, kram perut, lumpuh, gangguan penglihatan serta kesulitan bernafas.

\section{b. Clostridium tetani}

Clostridium tetani merupakan agen penyebab penyakit tetanus. Penyakit tetanus neonates (pada bayi) sering terjadi jika dalam proses kelahiran atau persalinan mengabaikan pemeliharaan tali pusat atau umbilicus (alat pemotong yang digunakan untuk memotong umbilicus tidak steril). Pada orang dewasa, penyakit tetanus ini mengikuti luka dalam dengan lubang yang kecil (luka tusuk). Clostridium tetani bersifat anaerobik, dan mampu memproduksi toxin tetanus. Gejala ditandai dengan sulitnya saat menelan, kejang-kejang otot yang parah, kejang pada rahang. 


\section{c. Staphylococcus aureus}

Staphylococcus adalah penyebab utama infeksi bernanah pada manusia yang terdapat di rongga hidung dan kulit sebagian besar populasi manusia. Jalur masuknya Staphylococcus ke tubuh melalui folikel rambut, tusukan jarum atau melalui saluran pernafasan. Prototipe lesi Staphylococcus adalah furunkel atau abses lokal lainnya yang dapat menyebabkan nekrosis jaringan (faktor dermatonekrotik). Staphylococcus aureus adalah bakteri aerob yang bersifat grampositif dan merupakan salah satu flora normal manusia pada kulit dan selaput mukosa. Staphylococcus aureus merupakan patogen utama pada manusia dan hampir setiap orang pernah mengalami infeksi Staphylococcus aureus yang bervariasi dalam beratnya, mulai dari keracunan makanan hingga infeksi kulit ringan sampai berat yang mengancam jiwa. Gejala yang dialami seperti muncul benjolan pada kulit yang penuh dengan nanah, peradangan, rasa sakit. Penderita penyakit infeksi yang disebabkan oleh bakteri Staphylococcus aureus umumnya diberi terapi berupa antibiotik seperti cloxacillin, dicloxacillin dan eritromycin.

\section{d. Staphylococcus epidermidis}

Staphylococcus epidermidis merupakan bakteri yang berkembang menjadi agen patogen utama pada infeksi nosokomial dan sepsis, terutama pada pasien yang menggunakan alat-alat implant di tubuhnya, seperti prostheses sendi, shunt serebrospina, kateter intravaskular, khususnya pada anak-anak, pasien usia lanjut dan pasien yang mengalami imunokompromise. Penyakit septicaemia dan endokarditis termasuk penyakit yang disebabkan oleh bakteri Staphylococcus epidermidis.

Gejala berupa demam, sakit kepala, dan kelelahan untuk anoreksia dan dyspnea.

\section{e. Streptococcus pneumoniae}


Pneumonia adalah peradangan paru yang menyebabkan nyeri saat bernafas dan keterbatasan intake oksigen. Pneumonia dapat disebarkan dengan berbagai cara antara lain pada saat batuk dan bersin (WHO, 2014). Bakteri penyebab pneumonia adalah Streptococcus pneumoniae (pneumococus).

Gejala Usia kurang dari 5 tahun rentan mengalami pneumonia berat dengan gejala batuk dan sukar bernapas. Sistem kekebalan tubuh anak pada usia tersebut juga sangat rentan sehingga mudah terinfeksi oleh penyakit yang ditularkan melalui udara.

Masa perawatan paling pendek adalah selama 3 hari dan paling lama adalah 36 hari. Pada pasien dewasa persentase lama perawatan paling tinggi yaitu 8-14 hari, dengan perawatan paling pendek selama 4 hari dan paling lama selama 27 hari.

\section{f. Treponema pallidum}

Sifilis adalah penyakit yang disebabkan oleh bakteri Treponema pallidum. Penyakit sifilis terbagi menjadi empat tahap, yaitu primer, sekunder, laten, dan tersier (Ain, Rachmatdinata, \& Djajakusumah, 2013). Tiap tahap menunjukkan gejala klinis yang berbeda. Bakteri Treponema pallidum dapat ditularkan melalui melalui dua cara, yaitu melalui ibu ke anak dan hubungan seksual yang tidak aman seperti berganti-ganti pasangan dan tidak menggunakan kondom.

Gejala-Gejala klinis penyakit tersebut akan tampak tiga minggu setelah terjadinya infeksi. Salah satu gejala klinis sifilis adalah ruam atau chancre pada kelamin. 


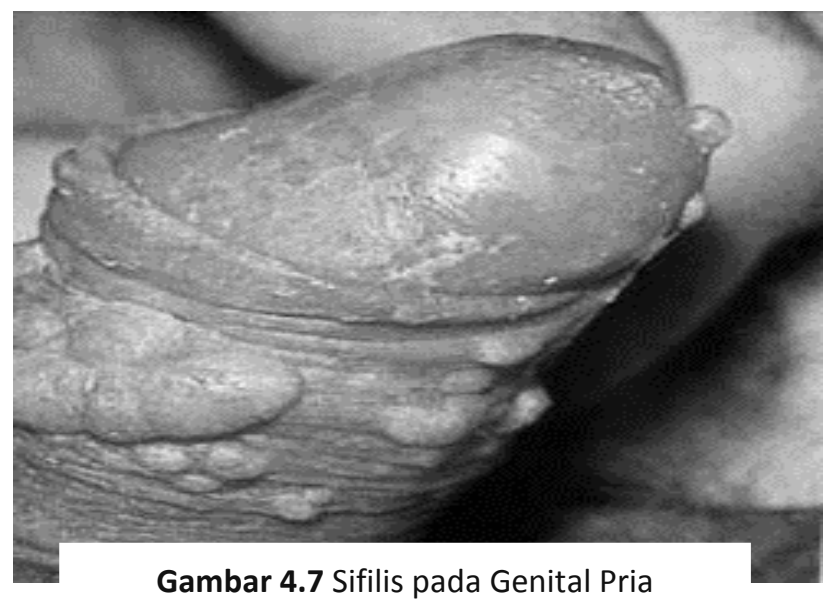

\section{g. Mycobacterium tuberculosis}

Tuberkulosis (TB) adalah suatu penyakit infeksi paling sering menyerang jaringan paru, disebabkan oleh Mycobacterium tuberculosis. Penyakit tuberkulosis (TB) paru ini dapat menyerang semua usia dengan kondisi klinis yang berbeda-beda atau tanpa dengan gejala sama sekali hingga manifestasi berat.

Pencegahan dari penyalit ini adalah menyediakan air bersih, pengelolaan limbah dan tinja rumah tangga, bebas vektor pembawa bibit penyakit seperti (tikus, kecoa, dan lalat), kepadatan hunian yang tidak melebihi persyaratan, sinar matahari pagi cukup menyinari ruangan, makanan dan minuman terhindar dari pencemaran. Selain itu rumah yang sehat harus memenuhi syarat pencegahan terjadinya kecelakaan baik yang timbul karena keadaan luar maupun dalam rumah antara lain konstruksi yang tidak mudah rusak dan roboh, persyaratan garis sempadan jalan, tidak mudah terbakar, dan tidak membuat penghuninya jatuh tergelincir. 


\section{h. Streptococcus pyogenes}

Radang tenggorokan atau amandel merupakan penyakit yang pernah dirasakan oleh hampir semua orang, yang disebabkan oleh bakteri Streptococcus pyogenes. Peradangan yang sangat hebat dapat menyebabkan angina ludwing (radang dasar mulut yang berat disertai pernanahan) sehingga akan menghambat aliran udara yang masuk melalui saluran pernafasan.

Gejala dari penyakit ini antara lain radang tenggorokan dapat ditandai seperti flu, batuk, demam, mual dan kelelahan

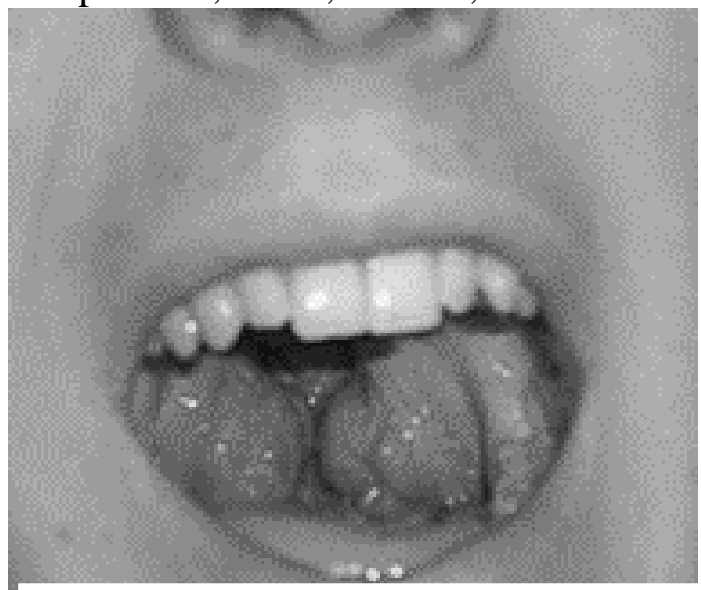

Gambar 4.8 Radang Tenggorokan

\section{i. Bacillus anthracis}

Penyakit antraks disebabkan oleh Bacillus anthracis. Manusia terjangkit antraks biasanya akibat kontak langsung atau tidak langsung dengan binatang atau bahan yang berasal dari binatang terinfeksi. Gejala dari penyakit ini:

\section{Antraks Kulit}

Sering disebut sebagai black eschar atau malignant pustule yang paling sering terjadi, yaitu lebih dari $90 \%$. Penderita biasanya mempunyai riwayat kontak dengan hewan 
atau produknya. Lesi pertama terjadi dalam waktu tiga sampai lima hari pasca inokulasi spora dan umumnya terdapat pada daerah ekstremitas, kepala dan leher (daerah terbuka). Lesi berwarna kemerahan, gatal dan tak sakit. Dalam kurun waktu 24-36 jam lesi berubah membentuk vesikel berisi cairan jernih.

2. Antraks Intestinal

Biasanya muncul 2-5 hari setelah tertelannya spora yang umumnya berasal dari santapan daging tercemar. Penderita biasanya berupa demam, nyeri perut difus dan disertai nyeri lepas. Feses bercampur darah atau berupa melena dengan konsistensi padat atau cair. Penderita kadang-kadang muntah berdarah atau berwarna seperti kopi. Asites muncul dua sampai empat hari sejak gejala pertama timbul. Kematian terjadi umumnya karena toksemia atau perforasi.

3. Antraks Orofaring

Gejalanya berupa edema leher dan pembesaran kelenjar limfe lokal dengan akibat kesulitan menelan dan kesulitan bernafas. Lesi di orofaring berupa ulkus dengan pseudomembran.

\section{j. Bacillus cereus}

Bacillus cereus merupakan bakteri yang menyebabkan keracunan dengan gejala muntah dan diare. Terdapat dua jenis toksin yang dihasilkan oleh Bacillus cereus, yaitu toksin yang menyebabkan diare (disebabkan oleh protein dengan berat molekul besar) dan toksin yang menyebabkan muntah atau emetik (disebabkan oleh peptida tahan panas dengan berat molekul rendah).

Masa inkubasi sekitar 1-5 jam. Toksin ini menyebabkan timbulnya gejala muntah, dan kadang-kadang diare. Strain yang ditemukan pada makanan penyebab keracunan Bacillus cereus yang mengandung bahan dasar nasi (Nababan \& Hasrudin, 2015). 


\section{k. Mycobacteria leprae}

Morbus Hansen (Lepra, Kusta) adalah infeksi menahun yang disebabkan Mycobacteria leprae primer yang menyerang saraf tepi, selanjutnya dapat menyerang kulit dan organ lainnya. Respon yang terjadi akibat infeksi Mycobacterium leprae dapat sangat berbeda, keadaan ini terjadi di bawah kontrol secara genetika. Bentuk kelainan yang terjadi tergantung tipe kusta yang terjadi seperti kusta stadium subklinis. Kusta stadium subklinis adalah keadaan dimana bakteri telah masuk ke dalam tubuh yang ditandai dengan pemeriksaan serologis yang positif namun individu tersebut tidak menunjukkan gejala klinis.

Gejala pada penyakit ini masa inkubasi sekitar 2-5 tahun kemudian akan muncul gejala awal penyakit yang bentuknya belum khas, berupa bercak-bercak dengan sedikit gangguan sensasi pada kulit disertai dengan berkurangnya produksi keringat setempat. Dalam beberapa tahun setelah kelainan tersebut ditemukan biasanya akan muncul gejala klinis yang karakteristik. Kelainan yang khas ini bervariasi, bisa pada kulit, saraf tepi maupun organ-organ lainnya tergantung tipe kusta.

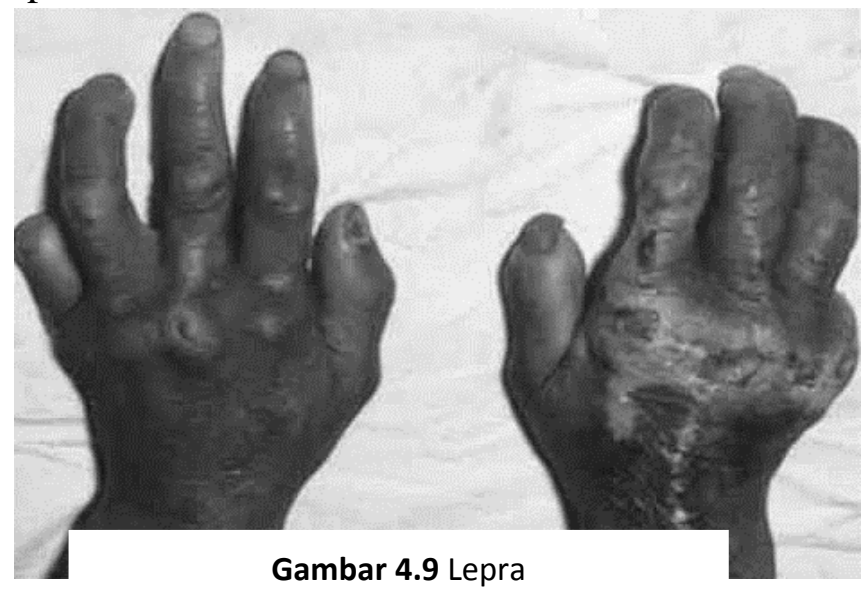




\section{Corynebacterium diphtheriae}

Difteri disebabkan oleh strain toksik kuman bacillus gram positif Corynebacterium diphtheriae. Difteri dapat berupa infeksi saluran napas atas, infeksi pada kulit atau berupa status karier tanpa timbulnya gejala. Difteri juga dapat menimbulkan berbagai komplikasi serius yang berakibat kematian.

Gejala klinis difteri yang paling sering ditemukan adalah demam dan disfagia. Gejala klinis lain yang didapati adalah batuk, nyeri tenggorok, dan bull neck. Gejala klinis yang jarang ditemukan yaitu suara serak, perdarahan pada pseudomembran, dan kejang.

Penularan difteri dapat dicegah melalui pemberian imunisasi toksoid difteri. Imunisasi dasar difteri pertusis tetanus (DPT) diberikan 3 kali sejak usia 2 bulan dengan interval 4-6 minggu.

\section{m. Clostridium perfringens}

Clostridium perfringens adalah bakteri anaerob gram positif yang mampu membentuk spora. Strain yang menjadi penyebab keracunan pangan adalah tipe A dengan enterotoksin yang dapat menyebabkan sakit perut akut dan diare.

Diare sering kali dianggap biasa sebab dengan atau tanpa pengobatan diare tersebut dapat sembuh sehingga tidak dilaporkan. Bagi balita penderita gizi buruk, diare tersebut akan berpengaruh nyata pada bobot badan dan status kesehatan umumnya sehingga pencapaian status gizi baik dan sehat menjadi lebih lama.

Gejala penyakit biasanya muncul 8-16 jam setelah mengkonsumsi makanan yang terkontaminasi, dan sembuh dengan sendirinya dalam 12-24 jam.

\section{n. Gardnerella vaginalis}

Vaginosis bakterial (VB) adalah suatu keadaan abnormal pada ekosistem vagina yang ditandai adanya 
konsentrasi flora normal vagina digantikan oleh konsentrasi tinggi bakteri anaerob yaitu Gardnerella vaginalis. Penyakit ini disebut juga vaginitis nonspesifik, vaginitis Gardnerella vaginalis atau vaginosis anaerobik.

Gejala klinis untuk bakterial vaginosis yang sering disebut sebagai kriteria Amsel yang berpendapat bahwa terdapat tiga dari empat gejala, yaitu adanya sekret vagina yang homogen, tipis, putih, melekat pada dinding vagina dan abnormal. $\mathrm{pH}$ vagina $>4,5$ serta tes amin positif, dengan sekret vagina yang berbau amis sebelum atau setelah penambahan KOH 10\% (Whiff test).

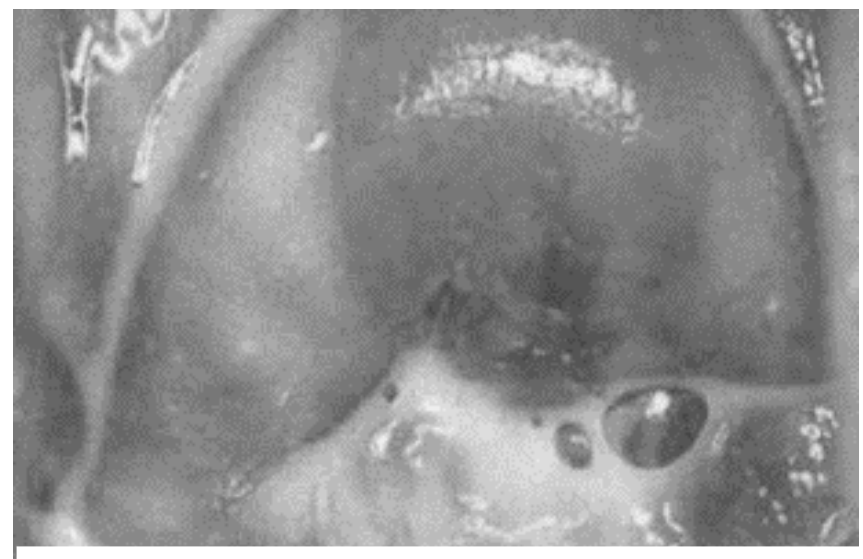

Gambar 4.10. Vaginosis bakterial pada Vagina

\section{o. Staphylococcus saprophyticus}

Staphylococcus saprophyticus umumnya ditemukan pada kasus ISK wanita muda yang seksual aktif. Staphylococcus saprophyticus mempunyai kemampuan adhesi pada epitel saluran urogenital lebih kuat tetapi semuanya mempunyai risiko yang sama dapat menyebabkan ISK. Staphylococcus melekat pada epitel saluran kemih melalui mekanisme yang berbeda dari Escherichia coli. 
Gejala dari penyalit ini dalam kondisi normal di dalam urine dapat ditemukan adanya bakteri, baik yang memberikan gejala (simptomatik) maupun tanpa gejala (asimptomatik). Gejala ISK juga dapat berupa nyeri atau tekanan di punggung atau perut bagian bawah, demam, terasa terbakar ketika buang air kecil dan sering buang air kecil.

\section{KESIMPULAN}

Bakteri patogen penyebab penyakit pada manusia dapat disebabkan oleh bakteri Gram positif dan bakteri Gram negatif.

\section{LATIHAN SOAL}

1. Jelaskan 3 contoh penyakit yang disebabkan oelah bakteri Gram negatif!

2. Jelaskan 3 contoh penyakit yang disebabkan oelah bakteri Gram positif! 


\section{DAFTAR PUSTAKA}

Amelia, Trisna. 2017.Buku Ajar Mikrobiologi. Umrah Press: Tanjungpinang

Bagg J, Mac Farlane TW, Poxton I, Miller CH, Smith AJ. 2002. Essentials of Microbiology for Dental Students. Oxford University Press: New York

Black, Jacquelyn G. 2002. Microbiology. John Wiley \& Sons Inc

Boleng, Didimus Tanah. 2015. Bakteriologi Konsep-Konsep

Dasar. Universitas Muhammadiyah Malang: Malang

Brock. TD. Madiqan. MT. 1991. Biology of Microorganisms.

Sixth ed. Prentice- HallInternational Inc

Cappuccino, JG. \& Sherman, N. 1987. Microbiology: A Laboratory Manual. The Benjamin/Cummings Publishing Company Inc: California.

Case, C.L. \& Johnson, T.R. 1984. Laboratory Experiments in Microbiology. Benjamin/Cummings Publishing Company, Inc: California.

Departemen Kesehatan RI. 2009. Peraturan Kepala BPOM RI No. HK.00.06.1.52.4011 tentang Batas Maksimum

Cemaran Mikroba dan Kimia dalam Makanan. Departemen Kesehatan RI: Jakarta

Dwijoseputro, D. 2005. Dasar-dasar Mikrobiologi. Djambatan: Jakarta

Fardiaz, S. 1993. Analisis Mikrobiologi Pangan. PT. Raja Grafindo: Jakarta

Faridah, Hayyun Durrotul dan Silvia K.S. 2019. Pemanfaatan Mikroorganisme Dalam Pengembangan Makanan Halal Berbasis Bioteknologi. Journal of Halal Product and Research, 2(1): 33-43.

Harmita dan Maksum Radji. 2005. Buku Ajar Analisis Hayati. Edisi Kedua. Departemen Farmasi FMIPA Universitas Indonesia : Depok 
Holt, J.G., Krieg, N.R., Sneath, P.H.A., Staley, J.T., \& Williams, S.T.

1994. Bergey's Manual of Determinative Bacteriology $9^{\text {th }} \mathrm{Ed}$.

Imam Supardi. dan sukamto. 1999. Mikrobiologi dalam

Pengolah dan Keamanan Pangan. Yayasan Adikarya

IKAPI. Bandung

Irianto, Koes. 2007. Dasar-dasar Mikrobiologi Jilid 1. Yrama

Widya: Bandung

Irianto, Koes. 2007. Dasar-dasar Mikrobiologi. Jilid 2. Yrama

Widya.: Bandung

Madigan et al., 1995. Biology of Microorganisms. Prentice Hall Inc: New Jersey

Maksum Radji. 2009. Buku Ajar Mikrobiologi Panduan Mahasiswa Farmasi dan Kedokteran. Penerbit Buku Kedokteran EGC: Jakarta

Metting, F.B. 1993. Soil Microbial Ecology. Applications in Agriculture and Environment Management. Marcel Dekker Inc: New York

Mitchell, R. 1974. Introduction to Environmental Microbiology.

Prentice-Hall, Englewood Cliffs: New Jersey

Moat, A.G. \& Foster, J.W. 1979. Microbial Physiology. John Wiley \& Sons

Murray PR, Rosenthal KS, Kobayashi GS, Pfaller MA. 1998.

Medical Microbiology $3^{\text {rd }}$ ed. Mosby Inc: St.Louis

Nicklin. J.K. Graeme-Cook. T. Paget \& R. Killington. 1999.

Instans Notes in Microbiology. Springer Verlag:

Singapore Pte, Ltd.

Nurhayati, B., Darmawati, S. 2017. Biologi Sel dan Molekuler.

PPSDMK Kemenkes RI: Jakarta

Padoli. 2016. Mikrobiologi dan Parasitologi Keperawatan. PPSDMK

Kemenkes RI: Jakarta

Pelczar and Chan. 2014. Dasar-dasar Mikrobiologi Jilid 1. UIP: Jakarta

Pelczar and Chan. 2014. Dasar-dasar Mikrobiologi Jilid 2. UIP: Jakarta 
Putri, Meganada Hiranya., Sukini., dan Yodong. 2017. Mikrobiologi. PPSDMK Kemenkes RI: Jakarta

Samaranayake LP. 2002. Essential Microbiology for Dentistry $2^{\text {nd }} E d$. Churchill Livingstone: London.

Schlegel, Hans G. 1994. Mikrobiologi Umum. Gadjah Mada University Press: Yogyakarta

Schlegel, H.G., 1986. General microbiology. Cambridge University Press: Cambridge

Stanier, R.Y., E.A. Adelberg, JL. Ingraham. 1980. The Microbial World. Prentice Hall Inc: New Jersey

Suharni, Theresia Tri dkk. 2008. Mikrobiologi Umum.

Universitas Atma Jaya: Yogyakarta

Sumarsih, Sri. 2003. Diktat Mikrobiologi Dasar. Jurusan Ilmu

Tanah. Fakultas Pertanian Upn"Veteran". Yogyakarta

Tortora Gerard J. et al. 1992. Microbiology an Introduction.

Fourth Ed. The Benjamin Cummings Publishing Company, Inc

Waluyo, Lud. 2007. Mikrobiologi Umum. UMM. Malang.

Williams \& Wilkins. Batimore. Maier, M.R., Pepper, I.L., \&

Gerba, C.P. 1999. Environmental Microbiology. PrenticeHall: Sandiego

Wikipedia Ensiklopedia Bebas. 2017. https://id.wikipedia.org 


\section{BIODATA PENULIS}

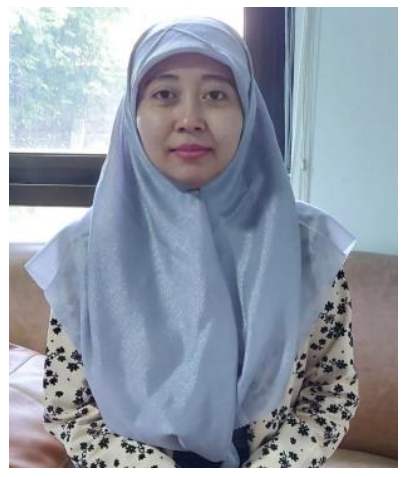

Chylen Setiyo Rini, S.Si., M.Si. lahir di Sidoarjo, 04 April 1985. Lulus sebagai Ahli Mikrobiologi tahun 2013, dan memperoleh gelar Sarjana Sains dari Prodi Biologi MIPA Institut Teknologi Sepuluh Nopember (ITS) Surabaya tahun 2009. Penulis melanjutkan studi S2 di Prodi Biologi Universitas Airlangga (UNAIR) lulus tahun 2013. Karir pendidikan dimulai tahun 2014 di Prodi Teknologi Laboratorium Medis Universitas Muhammadiyah Sidoarjo.

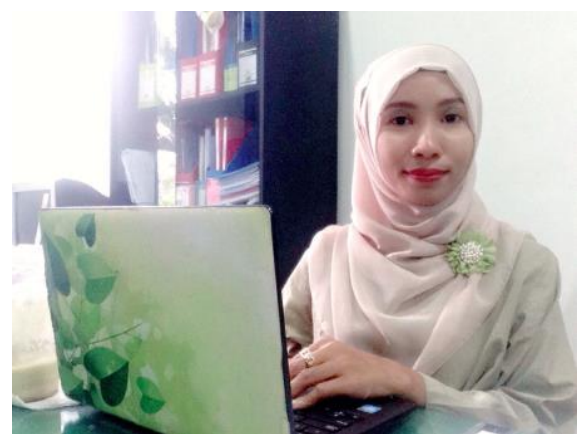

Jamilatur Rohmah, S.Si., M.Si. dilahirkan di Sidoarjo, 28 September 1985. Pada tahun 2009, penulis mendapatkan gelar Sarjana Sains dari jurusan Kimia FMIPA Universitas Negeri Surabaya (UNESA). Penulis melanjutkan Magister Kimia dari Institut Teknologi Sepuluh Nopember (ITS) Surabaya. Tahun 2012, penulis secara resmi mendapatkan gelar M.Si. Penulis mengawali karirnya sebagai Dosen di prodi Pendidikan IPA FPIP pada tahun 2014 dan tahun 2015 penulis menjadi Dosen di Prodi Teknologi Laboratorium Medis Muhammdiyah Sidoarjo. 